\title{
WestVirginiaUniversity
}

THE RESEARCH REPOSITORY @ WVU

Graduate Theses, Dissertations, and Problem Reports

2016

\section{Perceptions of Urban Forestry Employers}

Andrew Benjamin

Follow this and additional works at: https://researchrepository.wvu.edu/etd

\section{Recommended Citation}

Benjamin, Andrew, "Perceptions of Urban Forestry Employers" (2016). Graduate Theses, Dissertations, and Problem Reports. 5184.

https://researchrepository.wvu.edu/etd/5184

This Thesis is protected by copyright and/or related rights. It has been brought to you by the The Research Repository @ WVU with permission from the rights-holder(s). You are free to use this Thesis in any way that is permitted by the copyright and related rights legislation that applies to your use. For other uses you must obtain permission from the rights-holder(s) directly, unless additional rights are indicated by a Creative Commons license in the record and/ or on the work itself. This Thesis has been accepted for inclusion in WVU Graduate Theses, Dissertations, and Problem Reports collection by an authorized administrator of The Research Repository @ WVU. For more information, please contact researchrepository@mail.wvu.edu. 


\title{
Perceptions of Urban Forestry Employers
}

\author{
Andrew Benjamin
}
Thesis submitted to Davis College of Agriculture, Natural Resources and Design at West Virginia University

In Partial fulfillment of the requirement for the degree of Master of Science in Forestry

\author{
Gregory Dahle, Ph. D., Chair \\ David McGill, Ph. D. \\ Robert Burns, Ph. D. \\ Department of Forestry and Natural Resources
}

Morgantown, West Virginia

2016

Keywords: urban forestry, employers, survey, perceptions, skills, knowledge Andrew Benjamin 


\section{Abstract \\ Perceptions of Urban Forestry Employers}

Andrew Benjamin

Urban forestry is still a relatively new area of science and is still trying to establish itself as a legitimate scientific field and profession. Often urban forestry and arboriculture are conflated, and urban forestry has yet to achieve much of what arboriculture has in terms of recognition its and establishment. Landscape architects, traditional foresters, environmental scientists, horticulturalists all may find themselves in positions that can be classified in the urban forestry profession, which shows this lack of a standard definition for what is an urban forester. While there are many significant, potential benefits to a properly managed urban forest resource and employers recognize the value of the specialized education of urban foresters this lack of identity could lead to a lack of recognition in the eyes of the public and these overlapping professionals in the urban arena. The first step for arguing for this value is tackling the identity problem. It is important to know what employers are expecting of applicants and what applicants are delivering to employers. This is a question that has been asked many times in the past in many other professions: some as closely related to urban forestry as traditional forestry, arboriculture, or botany; though not much research has been done to answer this question specifically for urban forestry employers. It is in this way that a definition for what exactly an urban forester is can be found and the profession can ensure that entry-level urban foresters have the skills needed to perform their jobs effectively. The list of necessary skills is constantly changing and while the technical urban forestry and arboriculture skills remain relevant there has been a change that shows employers are now valuing not only communication skills, but team-based problem solving and leadership skills as well. 


\section{Acknowledgements}

I would like to thank my advisor, Dr. Dahle, and my committee members for their contributions to my project. I would like to thank NUCFAC and the UF 2020 research group for their help in my research. I would like to thank Sera Zerge, Keith O'Herrin, and Valerie Grant for introducing me to the world of social research and survey work. Thank you to all my graduate student peers for their help and support.

I would like to dedicate this thesis to my mother. Thank you for all that you have done for me. 


\section{Table of Contents}

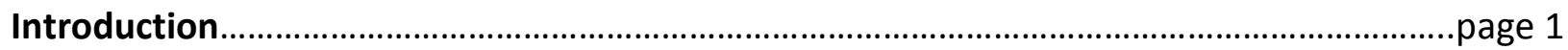

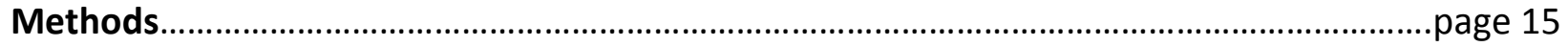

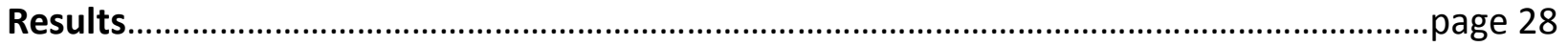

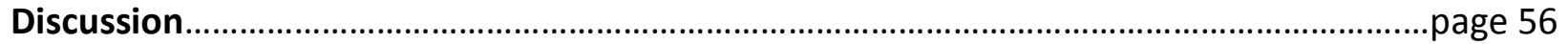

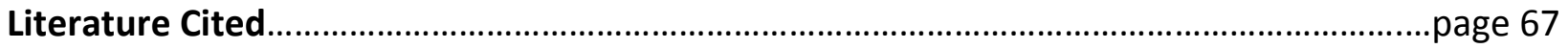

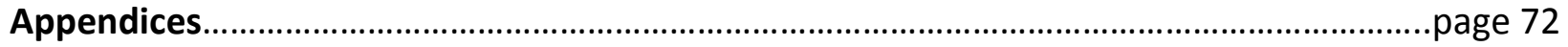




\section{List of Figures}

Figure 1: The two hundred most populous municipalities in the U.S. in 2010 according to the U.S. Census (U.S. Census 2010) page 19

Figure 2: Plot of 60 skills and knowledge valued by employers (Value) in an entry level urban foresters compared the rating of the same skills and knowledge possessed (Prevalence) in new hires of entry level urban forester. Responses are summarized from the mail questionnaire to the top 200 most populous municipalities in the USA. Value greater than three (neutral) suggests a skill is values and prevalence greater than three suggests new hires possess the given skill. page 35

Figure 3: Number of online responses received by day page 41

Figure 4: Plot of 60 skills and knowledge valued by employers (Value) in an entry level urban foresters compared the rating of the same skills and knowledge possessed (Prevalence) in new hires of entry level urban forester. Responses are summarized from the mail questionnaire to the top 200 most populous municipalities in the USA. Value greater than three (neutral) suggests a skill is values and prevalence greater than three suggests new hires possess the given skill page 49 


\section{List of Tables}

Table 1: The two hundred most populous municipalities in the U.S. in 2010 according to the U.S.

Census (U.S. Census 2010) page 16

Table 2: The number of mail questionnaires sent and received by state. page 29

Table 3: The ten highest valued urban forestry skills in response to the mailed survey.....page 30

Table 4: The ten lowest valued skills in response to the mailed survey. page 31

Table 5: The ten most prevalent skills in response to the mailed survey. page 32

Table 6: The ten least prevalent skills in response to the mailed survey. page 33

Table 7: Quadrant summary of mail responses. page 36

Table 8: The number of online responses received by state page 42

Table 9: The ten highest valued skills in response to the online survey. page 45

Table 10: The ten least valued skills in response to the online survey. page 46

Table 11: The ten most prevalent skills in response to the online survey page 46

Table 12: The ten least prevalent skills in response to the online survey page 47

Table 13: Quadrant summary of online responses. page 50

Table 14: Factors that were found to have significant relationships with skills using multiple regression and Benjamini-Hochberg procedures. Responses are from the mail survey of the top 200 most populous municipalities in the US. page 54

Table 15: Factors that were found to have significant relationships with skills using multiple regression and Benjamini-Hochberg procedures. Responses are from the online survey..page 55 


\section{Chapter 1: Introduction}

Urban forestry in the United States is a young profession. However, the practice of caring for trees near human populations has a long history. While the motivations for managing trees in or near cities may have varied through time, with the ancient Romans using trees to improve the aesthetics of their cities and the European cities in the Middle Ages protecting the surrounding forests for wood production and a source for raw materials, it can be said that trees have long been seen as a resource to centers of human populations (Konijnendijk and Randrup 2004). There are other examples of more formal urban tree management in cities; Zurich, Switzerland has had written plans for managing the city's trees that date back to the mid 1400's (Vaux 1980). It was during the mid-1800's that people started valuing urban forests for less utilitarian reasons. While people in population centers commonly saw trees an important and valuable part of life, it was during this time that the social value of trees began to be recognized (Lawrence 1993). At the beginning of this transition in the 1500's, trees in a city were used as architectural conventions or in walled-off private gardens of the wealthy. Gradually trees migrated in cities from this more private setting to urban open space of allees, or an alley in a formal garden or park bordered by trees or bushes. Across Europe in the 1500 's, allees were seen in cities, however they were typically restricted to the peripheries where there was more space and fewer people. This was the beginning of urban trees' shift to more public spaces. The 1600 's were the beginning of trees inhabiting a greater role in the urban landscape with the transformation of the peripheral allee into the more central pall mall. These formal recreation grounds for the poplar outdoor game of the same name showed up in many cities across Europe and, while the game they were named after is no longer in use, the 
word remains for famous landscapes across the world such as: the National Mall in Washington D.C.; the urban landscapes in former colonies like New Delhi, Jakarta, and Tunis; and in landscape planning practice in places like Ankara, Tokyo, and Bangkok (Lawrence 1993). Of course, these tree-related developments were not uniform across the entire continent of Europe. The urban forestry in the Netherlands more often took the form of tree-lined canals and in England the courtyard, or square, was most common (Lawerence 1993). The century after, that is to say the 1700 's, saw many major changes to trees in the cities in Europe. People grew wealthier, cities expanded, and the use of protective walls encircling the city become unneeded. All of these factors increased urban vegetation: former embattlements became open boulevards; new construction saw the incorporation of more open space; and the people with more resources pined for the luxuries of the aristocratic class. Gardens grew in popularity on private land, but also increasingly in parks open to the public for a fee. There is much evidence to show that the average city-dwellers in the 1700's desired urban trees and green space. However it was only in the 1800 's where these green places began to resemble modern day parks and similar ideas about what is now known as urban forestry today, began to take hold. Trees in the 1800's left the manicured gardens and squares and began to take their place in the cityscape. The rise of industry and crowded city centers increased the gulf between citydwellers and nature. This feeling of separation from nature combined with increasing concerns for public health lead to trees taking a larger role in urban areas. It was also at this time that officials and businesspeople realized the positive effect that trees had on property values. This way of thinking and type of urban design spread across Europe and then over to the United States and ultimately across the world, or at least as far as European colonial influence reached. 
It seems like a remarkable temporal distance to travel to explain something which is such a young profession and sometimes a seemingly novel idea, but as Lawrence (1993) says,

"The three main landscape elements that use trees are the tree-lined street, the private residence, and the public park. All three of these evolved from uses of trees developed before the middle of the nineteenth century."

This history being particularly interesting when examining the differences in terminology between American and European urban forestry today. Urban forestry today meaning traditional forestry practices in an area near or influenced largely by a human population in Europe currently instead of the meaning of urban forestry in the United States connoting the management of the urban forest resource. Despite the foundational ideas of urban forestry being created long ago, urban forestry only began to develop as a formal profession in the 1960's. One of the largest impetuses being the introduction of Dutch elm disease to the United State and the subsequent infection and death of large numbers of elms in the country in the early part of the 1900's, which introduced the idea of caring and managing the trees in cities (Deneke 1978). As cities and institutions began to give more attention to the field of arboriculture, the benefits and challenges of managing urban forest resources at a landscape level become clear.

The benefits of an urban forest can be numerous. Trees in the city can save energy by shading buildings in the summer thus reducing their cooling costs and provide shelter from cold winds in the winter, in the form of windbreaks, reducing heating costs (McPherson 1994, Napoli et al. 2015). Through the gas exchange between trees and the atmosphere, urban forests can capture pollutants from the air including: ozone, carbon monoxide, sulphur dioxide, and fine particulates (McPherson 1994). This removal of air pollutants alone can substantially improve 
urbanite health and save money on health care. Urban forest canopies can intercept rainfall and moderate surges in storm water runoff. This reduction in the amount of water running of the impervious surfaces of an urban area can reduce flood damage, save money on stormwater management, and help improve water quality. Plantings of tree and shrubs can form buffers to act as a screen or sound barrier, which can improve the aesthetics of an area and the quality of life of its residents (Dwyer et al. 1992). The benefits of urban trees are not limited to the biological world. There are many social benefits to urban trees and forests. Trees create an aesthetically pleasing area in which to recreate, which contributes to an overall more desirable environment and healthier psychological state. Urban trees have a positive psychological effect. Short amounts of time spent among urban trees can produce discernibly more positive moods (Hull 1992). Tree and shrubs planting around a house and in the surrounding area of a house can increase its real estate values. People pay more for property with well managed trees on them. This in turn raises the property value, which can benefit the local government through increased revenues from property taxes. Aspects of the urban forest resource, from street trees to iconic parks, can foster a sense of community around this shared resource (Dwyer et al. 1992).

Despite the diverse and numerous benefits afforded by a well-managed urban forest there are potential negative effects and substantial challenges having trees in urban areas. One positive function of the urban forest may impair another without proper management. An example could be frequent planting of an aesthetically pleasing tree that, while pleasing to look at, doesn't grow to the same heights more traditional shade trees would and thus does not provide the same amount of energy savings because it does not cast as much shade as a taller 
tree would (Nowak 1994). The potential deleterious effects of a mismanaged urban forest are not just limited to the tree within a city either. The introduction of exotic pest species and exotic tree species from cities can cause damage and reduce biodiversity in neighboring forest lands (Nowak et al. 2005). It would be an urban forester's duty to have a program in place for monitoring for exotic pests and plants and plan for how best to manage if such a problem arose. Public involvement is crucial to sustainable urban forestry and many negative consequences can arise if an urban forester does not sufficiently engage stakeholders (Elmendorf et al 2003). The human dimensions of urban forestry are very important and sometimes overlooked, but collaboration, or "buy-in," in the community is necessary and often affects the funding and sustainability of urban forestry programs (Elmendorf\& Luloff 2001). This level of collaboration and stakeholder participation also brings up the question of cultural inclusion. The United States is becoming increasingly diverse. Urban forestry professionals must be sensitive to cultural groups to reduce conflict, but also to utilize any valuable insights or talents within the community (Johnston \& Shimada 2004). These are just a few examples of why knowledgeable and skilled individuals are needed as managers of our urban forests.

Skilled and knowledgeable mangers can greatly increase the function of an urban forest resource and this in turn increases the benefits the resource yields to the people that comprise the urban population. Nowak \& Dwyer (2007) state, "Inadequate understanding of the wide range of benefits, costs, and expected outcomes of urban vegetation management options, as well as interactions among them, may drastically reduce the contribution of vegetation toward improving urban environments and quality of life." With so much to gain and so much to potentially lose, there is a serious need for urban foresters that appreciate and are responsive 
to this complexity (Dwyer et al. 2003, Deneke 1978, Dwyer et al. 1992, Nowak 2001, Nowak \& Dwyer 2007). With the exception of large urban parks and expansive residential yards, urban environments are often inherently hostile to trees. The fact that trees are so long lived and often must reach maturity to give the most benefits often conflicts with the much shorter timeline of human activity. Often the relatively rapid changes that occur in a city: new development, road construction, renovation; where trees are damaged or removed can greatly disrupt the long-term benefits that the urban forest resource can provide. Additionally, the practically infinite number of variations in the specific environment such as surrounding hardscape, soil conditions, or microclimate; a tree is placed in a city adds to the challenge (Dwyer et al. 2003). Good urban foresters must keep both the wide variety of benefits and potential problems in mind when managing urban trees, while staying cognizant of the long lifespan of trees to ensure they are planning adequately far into the future to reap the largest amount, most consistent, and sustainable benefits (Dwyer et al. 1992).

The resource of the urban forest is a valuable one and is only becoming more important to more people as time goes on. Urban areas are home to the majority of the population of the United States and this proportion is continuing to grow. The amount of urban land has doubled between 1969 and 1994 (Nowak et al. 2001). This trend extends beyond the United States as well with more than half of the world's population now living in urban areas. It is projected that by the year 2045 the number of people living in cities with increase from four billion to six billion (World Bank 2015) and that human activity currently affects every ecosystem on the planet (Vitousek et al. 1997). The management of trees was also a major part of the most recent talks about mitigation of the negative effects of climate change (Harris \& Stolle 2016). 
These swelling urban populations contribute two thirds of the greenhouses and are also the most vulnerable to storm surges showing the need for urban populations to address these challenges (World Bank 2015). Additionally, the forests around urban areas are affected by this expansion with development pushing into woodlands and creating forest fragments that become part of the urban forest. This extension of the urban, or human, ecosystem further grows humans' influence on the environment. Natural resource professionals need to develop a way to include this human presence in management because it is playing a larger and larger role in these new ecosystems (Mclntyre et al. 2000). This growing urban and suburban sprawl is eroding the ability to clearly separate urban and rural management issues. This gradual merging makes urban forestry even more complicated as it touches traditional practices (Dwyer \& Childs 2004). This growing urban population also means that for more and more people the urban forest is how they experience nature and learn about larger forestry issues. Urban forestry has the influence over an increasing number of people's understanding of and connection to nature. This influence could potentially bring people to understand the value of urban trees which would be a benefit for all of society (Nowak et al. 2005). As more people live in cities, urban forests and those who manage them can have a positive effect on the well-being of more people.

While the skills of a traditional forester are still relevant, the relatively new application of urban forest management introduced the human element in a much larger and significantly novel way. The need for multidisciplinary collaboration is needed, as well as the ability for an urban forester to be able to manage conflict and meaningfully engage stakeholders (Konijnendijk 2003). 
The multicultural aspect of urban forestry is unique challenge. Accounting for issues of social justice and differing value systems among different ethnic groups while ensuring inclusion and attempting to create community buy-in is an aspect of management much more prominent for the urban forester (Johnston \& Shimada 2004). The human aspect, in general, of urban forestry is a challenge specific to the field over other areas of natural resources that don't as always directly involve the public. Urban foresters must consider not just the most effective management for the urban forest resource in a biological sense, but also consider the human aspects of social and political concerns as well (Dwyer et al. 2003). To best serve trees in this complex environment, an urban forester must consider a wide range of professionals and managers in an equally wide range of fields in the course of management.

Beyond the consideration of other managers and professionals in the urban arena, the involvement of the public is crucial. It is necessary for urban foresters to go beyond scientific expertise and get public participation and buy-in before their decisions can be considered legitimate (Janse \& Konijnendijk 2007). Furthermore going beyond being able to elicit public input, but also it is within an urban forester's duties to facilitate adequate communication between policy makers and community facilitators. All while communicating a clear and attractive vision of what will be the reward for the hard work of the planning process. Examples can be seen in traditional forestry of the danger of operating without the public's endorsement and refusal to adapt to new practices. It is through the example of traditional forestry that urban foresters can see the value of public input when managing a public resource (Luckert 2006). The high value of the resource urban foresters administer makes this communication crucial. It will be through public involvement and education that urban 
foresters will avoid the obscure standing of many traditional forestry professionals (Hull 2011).

It is ultimately a public resource and it is through public engagement, as seen in traditional forestry, that new ideas for management and a feeling of shared responsibility can be created (Barrett \& Baumann 1994).

After reviewing the numerous benefits and challenges of managing the urban forest resource, the need for skilled urban forestry professional is patent. The challenge of managing an urban forest is not just the physical aspects of the trees and the environment in which they are placed. Konijnendijk states, "Urban forestry is generally defined as the art, science, and technology of managing trees and forest resources in and around urban community ecosystems for the physiological, sociological, economic, and aesthetic benefits trees provide society." Urban forestry is a complicated field that sits on the intersection of many areas of specialized knowledge. Even its definition is confused and contested. In Europe, despite its long history of urban vegetation management, the term "urban forestry" more often refers to traditional forestry practices near or under the influence of urban centers and not urban greenspace as in the United States (Konijnendijk 1997). It is this complexity as a profession that creates the need for well trained, competent individuals. This need is stated explicitly in the action plan of the Nation Urban and Community Forestry Advisory Committee for 2016-2026 (NUCFAC 2016). The plan not only states an increase in highly educated urban forestry professionals is needed, but also many other key issues relating to high level management. This plan lists effective leadership, increasing professionalism, improved management and maintenance, and an awareness of issues regarding social justice and multicultural inclusion, as just some of the key issues facing the profession in the next ten years. The need for qualified entry-level candidates 
is something seen in other professional societies as well. The International Society of Arboriculture also recognizes the challenge of finding individuals in this field (Hauer et al. 2015).

There have been numerous surveys of employers in the fields of forestry and other aspects of the green industry to determine if recent graduates are performing well in the entrylevel jobs (Beidler et al. 2006, Bullard et al. 2014, Brown \& Lassoie 1998, McPherson 1984, Sample 1999, Sundberg et al. 2011, VanDerZanden 2009). Generally, it seems students are considered adequately prepared for the work they are expected to perform with command over all of the necessary technical skills (Beidler, K. et al. 2006, Brown T. \& Lassoie J. 1998, Sample, V. 1999, VanDerZanden, M. 2009). It is the interpersonal skills that are often found lacking by employees: such as; written communication, verbal communication, managing employees, clientele interactions, organizational skills, public speaking, problem solving, and ethics. While the technical skills are still considered important and necessary to the job, these interpersonal skills are often considered just as valuable by employers. The ability of new employees in regards to these skills is not equal to the importance of said skills. Though there seems to be a pattern in natural resource and green industry jobs, it is important to continually and carefully examine what employers are expecting and what they are encountering in the recent graduates applying for their open positions. In some cases, there is a significant disconnect between what skills a recent graduate may anticipate are valued by and employers and reality (Sundberg et al. 2011). Further, while many parallels can be drawn between urban forestry and other professions in the green industry, urban forestry is unique in the position it holds in the public eye and at the cross-section of so many fields of science and arenas of management. Even assessments in arboriculture, from which urban forestry arguably sprang, 
are not close enough to draw meaningful information from for the field of urban forestry. If it is unknown whether recent graduates from urban forestry programs are capable of the duties expected of them, not only is the urban forest resource and all the benefits it affords put at risk, but the legitimacy of the profession of urban forestry is put in jeopardy.

The way forward is to clearly define the urban forestry professional. It must be asked what does an individual need to know to start out in the field of urban forestry and eventually grow into a competent urban forestry professional? What does a qualified entry-level urban forester look like? What makes an individual valuable to an employer? One can turn to the theory of human capital for a suitable metric. The idea that people themselves are valuable contributions to the economy and often an unexamined portion of society (Schultz 1961). It is difficult, and can be somewhat uncomfortable putting an economic value on human beings, but economists have found a way to define the value of people in an economy: education. The primary measure of human capital is education (Sweetland 1996) and the investments that people make in themselves in the form of education yield returns just like any other investment (Psacharopoulos \& Patrinos 2002). Education and knowledge translates to real money. The next step is to determine what exactly makes education valuable. For instance, given the variability of college students, it would be valuable to find what part of a college degree or experience makes a graduate valuable (Norwood \& Henneberry 2006). This a very complex question and there are many ways to find this value. The level of education attainment and the grades earned while completing those degrees are sometimes seen as a quality indicator of a degree-holder's competency and knowledge (Barkley et al. 1999), but are not always seen as the deciding factor used by employers (Briggeman \& Norwood 2011). One important factor is 
the opinion of employers. As Heyboer (2000) says, "The quality of education relies on many factors including the skills employers expect graduates to possess." The result is that many studies rely on employers to decide on what skills and knowledge are important.

Researchers have attempted to capture employer's assessment of entry-level professionals in an attempt to find what skills are the valuable in many different fields. These attempts have occurred in fields closely related to urban forestry; such as forestry, agriculture, landscape management, botany, horticulture, and arboriculture; and professions that urban forestry shares the urban arena with such as architecture and generally in the form of general employer satisfaction (Samlpe et al. 2015, Norwood \& Henneberry 2006, Briggeman \& Norwood 2011, Beidler et al. 2006, Brown \& Lassoie 1998, Michael \& Dasmohapatra 2001, McPherson 1984, Sample et al. 1999, Shannon 2012, Sundberg et al. 2011, VanDerZanden \& Reinert 2009). Some studies include the opinions of educators along with employers, or look solely to the educators, to identify a clearer picture of all the skills, knowledge and credentials necessary for entry-level applicants to be successful in their chosen professions (Elmendorf et al. 2005, Pritts \& Park 2013). A method that is used in the field of natural resource managers generally as academia works to keep step with a constantly, and often quickly changing profession (Rupp 2012). These studies are further from the reality of the workplace, but still offer guidance in what skills as seen as valuable and provide a fuller picture of the ideal entrylevel candidate. Further, such studies often provide a forum for employers, students and educational institutions in which to interact (Heyboer 2000). Recent graduates, employers, and entry-level applicants are three closely related factors that form the foundation of a professions future. Many studies that look at curriculum are still trying to answer the question of what 
skills do employers expect from entry-level applicants. This interconnectedness can be seen when attempts to revise university curriculums reach out to alumni and employers (Bullard et al. 2014). The value of including employers in the assessment entry-level applicants has been seen in the related field of botany (Sundberg et al. 2011). Botany, like urban forestry, is specialized and plant-based field with high value that still struggles to stake its own space in the professional and academic world. It was found that there was a large disconnect between how graduate students and employers assessed the skills that the soon-to-be applicants possessed. It was discovered that many of the skills the student felt were their strongest were found to be their weakest by the employers. The same is seen on the practical management side of plant focused professions with the field of horticulture facing similar problems (Pritts \& Park 2013). Researchers saw the necessity of defining horticulture because it was slowly disappearing from university majors lists as it was being absorbed into other plant-based departments. While distinct and significant, horticulture suffers from a lack of definite skills, which had led students to not recognize its value as a field of study or as a career. A field cannot argue its value if there is not agreement as to what constitutes the field. It is studies such as these that exemplify the importance of including employers is the creation of standards for young professionals, but finding the employers is not always easy. One role of this research is to discover what skills current managers find important in new hires, so that the profession can take shape in a meaningful direction.

Urban forestry is still struggling with its identity. There are not many studies dedicated to establishing what skills, knowledge and credentials make an urban forester. One must look to related fields either in the family tree of natural resource management, such as forestry or 
agriculture, or fields in the urban setting, such as horticulture or landscape management. The most useful studies that offer data for urban foresters as to what employers value and expect are the secondary focus of arboriculture surveys. The developing profession of urban forestry would benefit from a study that directly surveys urban forest employers as to the skills, knowledge and credentials they value. This thesis describes a two complimentary surveys designed to query public and private urban forest managers as to the skills and knowledge that are important in entry level urban foresters. Once this information is captured, a base of knowledge can be formed to further examine the field of urban forestry and the professionals that inhabit it. 


\section{Methods}

The study area of this project was all fifty states of the United States. The data was gathered with two surveys. One was a physical survey mailed to the urban forestry employers of the two hundred most populous cities in the United States. The second survey was an online, "snowball" survey. This was distributed through several professional networks with the intent to reach as many people as possible.

\section{Urban Forestry Employer Selection Process}

Given the difficulties in identifying and contacting employers in urban forestry, it was decided that the research would use two surveys to gather data. The first survey would be a physical survey sent through the United States Postal Service and follow the Dillman Method of mail surveys (Dilllman et al. 2009). The second survey would be an online, "snowball" survey sent through all the professional networks at the researcher's disposal. The mailed survey was designed to reach larger U.S. municipalities and the snowball survey was designed to reach smaller municipalities, private companies and not-for-profit organizations.

\section{Mailed Questionnaire}

The mailed questionnaire was sent out to the two hundred most populous municipalities in the United States (Table 1 \& Figure 1) as of the year 2010 (U.S. Census Bureau, 2010). The top two hundred municipalities were chosen because it was assumed that being larger in population these cities would have a larger tax base by definition and potentially have larger and potentially more proactive urban forestry programs because of the greater 
resources. Additionally, it was reasoned that municipalities were the most reliable employers of urban foresters and that surveying them would yield a better understanding of the work of entry-level urban forestry are expected to perform. Beyond the question of available resources of the municipalities, the study was limited to the top two hundred most populous cities since there is no professional organization or national directory to allow an estimate of how many employers in the field of urban forestry exist. There are certainly more employers of urban foresters in the United States, in both public and private sectors, than those in its most populous cities. Even at the local government level there are also counties, towns, and management districts. Yet with no definitive list of employers to turn toward, we realize it would be difficult to obtain contact information to which we could mail the survey. The limited scope of the mail survey was simply to have a definable population on which to focus the survey. It was for this reason that an online survey to complement this mail survey was decided to be necessary.

Table 1: The two hundred most populous municipalities in the U.S. in 2010 according to the U.S. Census (U.S. Census 2010)

\begin{tabular}{|c|c|c|c|c|c|c|c|}
\hline Rank & Municipality & Rank & Municipality & Rank & Municipality & Rank & Municipality \\
\hline 1 & New York, New York & 51 & $\begin{array}{l}\text { New Orleans, } \\
\text { Louisiana }\end{array}$ & 101 & $\begin{array}{l}\text { Birmingham, } \\
\text { Alabama }\end{array}$ & 151 & Elk Grove, California \\
\hline 2 & Los Angeles, California & 52 & $\begin{array}{l}\text { Bakersfield, } \\
\text { California }\end{array}$ & 102 & $\begin{array}{l}\text { Spokane, } \\
\text { Washington }\end{array}$ & 152 & Salem, Oregon \\
\hline 3 & Chicago, Illinois & 53 & Tampa , Florida & 103 & $\begin{array}{l}\text { Rochester, New } \\
\text { York }\end{array}$ & 153 & $\begin{array}{l}\text { Lancaster, } \\
\text { California }\end{array}$ \\
\hline 4 & Houston, Texas & 54 & Honolulu, Hawaii & 104 & Des Moines, lowa & 154 & Corona, California \\
\hline 5 & Philadelphia, Pennsylvania & 55 & Aurora, Colorado & 105 & Modesto, California & 155 & Eugene, Oregon \\
\hline 6 & Phoenix, Arizona & 56 & $\begin{array}{l}\text { Anaheim, } \\
\text { California }\end{array}$ & 106 & $\begin{array}{l}\text { Fayetteville, North } \\
\text { Carolina }\end{array}$ & 156 & $\begin{array}{l}\text { Palmdale, } \\
\text { California }\end{array}$ \\
\hline 7 & San Antonio, Texas & 57 & $\begin{array}{l}\text { Santa Ana, } \\
\text { California }\end{array}$ & 107 & $\begin{array}{l}\text { Tacoma, } \\
\text { Washington }\end{array}$ & 157 & Salinas, California \\
\hline
\end{tabular}




\begin{tabular}{|c|c|c|c|c|c|c|c|}
\hline 8 & San Diego, California & 58 & St. Louis, Missouri & 108 & Oxnard, California & 158 & $\begin{array}{l}\text { Springfield, } \\
\text { Massachusetts }\end{array}$ \\
\hline 9 & Dallas, Texas & 59 & $\begin{array}{l}\text { Riverside, } \\
\text { California }\end{array}$ & 109 & $\begin{array}{l}\text { Fontana city, } \\
\text { California }\end{array}$ & 159 & $\begin{array}{l}\text { Pasadena city, } \\
\text { Texas }\end{array}$ \\
\hline 10 & San Jose city, California & 60 & $\begin{array}{l}\text { Corpus Christi } \\
\text { city, Texas }\end{array}$ & 110 & $\begin{array}{l}\text { Columbus city, } \\
\text { Georgia }\end{array}$ & 160 & $\begin{array}{l}\text { Fort Collins city, } \\
\text { Colorado }\end{array}$ \\
\hline 11 & Austin city, Texas & 61 & $\begin{array}{l}\text { Lexington, } \\
\text { Kentucky }\end{array}$ & 111 & $\begin{array}{l}\text { Montgomery city, } \\
\text { Alabama }\end{array}$ & 161 & Hayward, California \\
\hline 12 & Indianapolis, Indiana & 62 & $\begin{array}{l}\text { Pittsburgh, } \\
\text { Pennsylvania }\end{array}$ & 112 & $\begin{array}{l}\text { Moreno Valley, } \\
\text { California }\end{array}$ & 162 & Pomona, California \\
\hline 13 & Jacksonville, Florida & 63 & Anchorage, Alaska & 113 & $\begin{array}{l}\text { Shreveport, } \\
\text { Louisiana }\end{array}$ & 163 & $\begin{array}{l}\text { Cary, North } \\
\text { Carolina }\end{array}$ \\
\hline 14 & San Francisco, California & 64 & $\begin{array}{l}\text { Stockton, } \\
\text { California }\end{array}$ & 114 & Aurora, Illinois & 164 & Rockford, Illinois \\
\hline 15 & Columbus, Ohio & 65 & Cincinnati, Ohio & 115 & Yonkers, New York & 165 & Alexandria, Virginia \\
\hline 16 & Charlotte, North Carolina & 66 & $\begin{array}{l}\text { St. Paul, } \\
\text { Minnesota }\end{array}$ & 116 & Akron city, Ohio & 166 & $\begin{array}{l}\text { Escondido, } \\
\text { California }\end{array}$ \\
\hline 17 & Fort Worth, Texas & 67 & Toledo, Ohio & 117 & $\begin{array}{l}\text { Huntington Beach, } \\
\text { California }\end{array}$ & 167 & McKinney, Texas \\
\hline 18 & Detroit, Michigan & 68 & $\begin{array}{l}\text { Greensboro, North } \\
\text { Carolina }\end{array}$ & 118 & $\begin{array}{l}\text { Little Rock, } \\
\text { Arkansas }\end{array}$ & 168 & Kansas City, Kansas \\
\hline 19 & El Paso, Texas & 69 & $\begin{array}{l}\text { Newark, New } \\
\text { Jersey }\end{array}$ & 119 & Augusta, Georgia & 169 & Joliet, Illinois \\
\hline 20 & Memphis, Tennessee & 70 & Plano, Texas & 120 & Amarillo, Texas & 170 & $\begin{array}{l}\text { Sunnyvale, } \\
\text { California }\end{array}$ \\
\hline 21 & Seattle, Washington & 71 & $\begin{array}{l}\text { Henderson, } \\
\text { Nevada }\end{array}$ & 121 & Glendale, California & 171 & Torrance, California \\
\hline 22 & Denver, Colorado & 72 & Lincoln, Nebraska & 122 & Mobile, Alabama & 172 & $\begin{array}{l}\text { Bridgeport, } \\
\text { Connecticut }\end{array}$ \\
\hline 23 & $\begin{array}{l}\text { Washington, District of } \\
\text { Columbia }\end{array}$ & 73 & Buffalo, New York & 123 & $\begin{array}{l}\text { Grand Rapids, } \\
\text { Michigan }\end{array}$ & 173 & $\begin{array}{l}\text { Lakewood, } \\
\text { Colorado }\end{array}$ \\
\hline 24 & Boston, Massachusetts & 74 & $\begin{array}{l}\text { Jersey City, New } \\
\text { Jersey }\end{array}$ & 124 & Salt Lake City, Utah & 174 & Hollywood, Florida \\
\hline 25 & Nashville, Tennessee & 75 & $\begin{array}{l}\text { Chula Vista, } \\
\text { California }\end{array}$ & 125 & Tallahassee, Florida & 175 & $\begin{array}{l}\text { Paterson, New } \\
\text { Jersey }\end{array}$ \\
\hline 26 & Baltimore, Maryland & 76 & $\begin{array}{l}\text { Fort Wayne, } \\
\text { Indiana }\end{array}$ & 126 & $\begin{array}{l}\text { Huntsville, } \\
\text { Alabama }\end{array}$ & 176 & Naperville, Illinois \\
\hline 27 & Oklahoma City, Oklahoma & 77 & Orlando, Florida & 127 & $\begin{array}{l}\text { Grand Prairie, } \\
\text { Texas }\end{array}$ & 177 & Syracuse, New York \\
\hline 28 & Louisville, Kentucky & 78 & $\begin{array}{l}\text { St. Petersburg, } \\
\text { Florida }\end{array}$ & 128 & $\begin{array}{l}\text { Knoxville, } \\
\text { Tennessee }\end{array}$ & 178 & Mesquite, Texas \\
\hline 29 & Portland, Oregon & 79 & Chandler, Arizona & 129 & $\begin{array}{l}\text { Worcester, } \\
\text { Massachusetts }\end{array}$ & 179 & Dayton, Ohio \\
\hline 30 & Las Vegas, Nevada & 80 & Laredo, Texas & 130 & $\begin{array}{l}\text { Newport News, } \\
\text { Virginia }\end{array}$ & 180 & Savannah, Georgia \\
\hline
\end{tabular}




\begin{tabular}{|c|c|c|c|c|c|c|c|}
\hline 31 & Milwaukee, Wisconsin & 81 & Norfolk, Virginia & 131 & Brownsville, Texas & 181 & $\begin{array}{l}\text { Clarksville, } \\
\text { Tennessee }\end{array}$ \\
\hline 32 & Albuquerque, New Mexico & 82 & $\begin{array}{l}\text { Durham, North } \\
\text { Carolina }\end{array}$ & 132 & $\begin{array}{l}\text { Overland Park, } \\
\text { Kansas }\end{array}$ & 182 & Orange, California \\
\hline 33 & Tucson, Arizona & 83 & $\begin{array}{l}\text { Madison, } \\
\text { Wisconsin }\end{array}$ & 133 & $\begin{array}{l}\text { Santa Clarita , } \\
\text { California }\end{array}$ & 183 & $\begin{array}{l}\text { Pasadena, } \\
\text { California }\end{array}$ \\
\hline 34 & Fresno, California & 84 & Lubbock, Texas & 134 & $\begin{array}{l}\text { Providence, Rhode } \\
\text { Island }\end{array}$ & 184 & $\begin{array}{l}\text { Fullerton, } \\
\text { California }\end{array}$ \\
\hline 35 & Sacramento, California & 85 & Irvine , California & 135 & $\begin{array}{l}\text { Garden Grove, } \\
\text { California }\end{array}$ & 185 & Killeen, Texas \\
\hline 36 & Long Beach, California & 86 & $\begin{array}{l}\text { Winston-Salem, } \\
\text { North Carolina }\end{array}$ & 136 & $\begin{array}{l}\text { Chattanooga, } \\
\text { Tennessee }\end{array}$ & 186 & Frisco, Texas \\
\hline 37 & Kansas City , Missouri & 87 & $\begin{array}{l}\text { Glendale, } \\
\text { Arizona }\end{array}$ & 137 & $\begin{array}{l}\text { Oceanside, } \\
\text { California }\end{array}$ & 187 & Hampton, Virginia \\
\hline 38 & Mesa , Arizona & 88 & Garland, Texas & 138 & $\begin{array}{l}\text { Jackson, } \\
\text { Mississippi }\end{array}$ & 188 & McAllen, Texas \\
\hline 39 & Virginia Beach, Virginia & 89 & Hialeah , Florida & 139 & $\begin{array}{l}\text { Fort Lauderdale, } \\
\text { Florida }\end{array}$ & 189 & Warren, Michigan \\
\hline 40 & Atlanta, Georgia & 90 & Reno, Nevada & 140 & $\begin{array}{l}\text { Santa Rosa, } \\
\text { California }\end{array}$ & 190 & $\begin{array}{c}\text { Bellevue, } \\
\text { Washington }\end{array}$ \\
\hline 41 & $\begin{array}{l}\text { Colorado Springs, } \\
\text { Colorado }\end{array}$ & 91 & $\begin{array}{l}\text { Chesapeake, } \\
\text { Virginia }\end{array}$ & 141 & $\begin{array}{l}\text { Rancho Cucamonga } \\
\text {, California }\end{array}$ & 191 & $\begin{array}{l}\text { West Valley City, } \\
\text { Utah }\end{array}$ \\
\hline 42 & Omaha, Nebraska & 92 & Gilbert, Arizona & 142 & $\begin{array}{l}\text { Port St. Lucie, } \\
\text { Florida }\end{array}$ & 192 & $\begin{array}{l}\text { Columbia, South } \\
\text { Carolina }\end{array}$ \\
\hline 43 & Raleigh , North Carolina & 93 & $\begin{array}{l}\text { Baton Rouge, } \\
\text { Louisiana }\end{array}$ & 143 & Tempe, Arizona & 193 & Olathe , Kansas \\
\hline 44 & Miami , Florida & 94 & Irving, Texas & 144 & Ontario , California & 194 & $\begin{array}{l}\text { Sterling Heights, } \\
\text { Michigan }\end{array}$ \\
\hline 45 & Oakland, California & 95 & $\begin{array}{l}\text { Scottsdale, } \\
\text { Arizona }\end{array}$ & 145 & $\begin{array}{l}\text { Vancouver, } \\
\text { Washington }\end{array}$ & 195 & $\begin{array}{l}\text { New Haven, } \\
\text { Connecticut }\end{array}$ \\
\hline 46 & Minneapolis, Minnesota & 96 & $\begin{array}{l}\text { North Las Vegas, } \\
\text { Nevada }\end{array}$ & 146 & Cape Coral , Florida & 196 & Miramar, Florida \\
\hline 47 & Tulsa , Oklahoma & 97 & $\begin{array}{l}\text { Fremont, } \\
\text { California }\end{array}$ & 147 & $\begin{array}{l}\text { Sioux Falls, South } \\
\text { Dakota }\end{array}$ & 197 & Waco, Texas \\
\hline 48 & Cleveland, Ohio & 98 & Boise City, Idaho & 148 & $\begin{array}{l}\text { Springfield, } \\
\text { Missouri }\end{array}$ & 198 & $\begin{array}{l}\text { Thousand Oaks, } \\
\text { California }\end{array}$ \\
\hline 49 & Wichita, Kansas & 99 & $\begin{array}{l}\text { Richmond, } \\
\text { Virginia }\end{array}$ & 149 & Peoria , Arizona & 199 & Cedar Rapids, lowa \\
\hline 50 & Arlington, Texas & 100 & $\begin{array}{l}\text { San Bernardino, } \\
\text { California }\end{array}$ & 150 & $\begin{array}{l}\text { Pembroke Pines, } \\
\text { Florida }\end{array}$ & 200 & $\begin{array}{l}\text { Charleston, South } \\
\text { Carolina }\end{array}$ \\
\hline
\end{tabular}




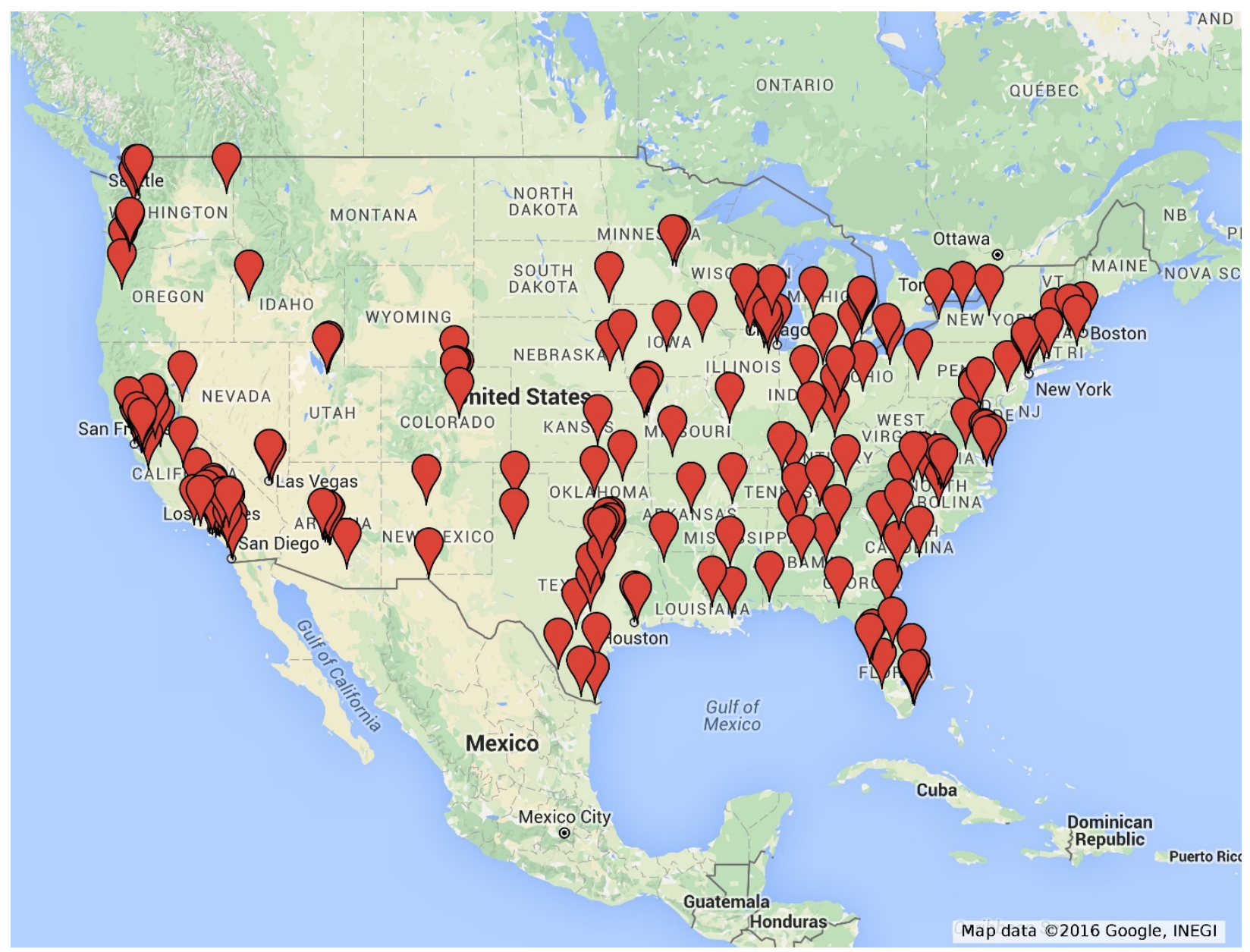

Figure 1: The two hundred most populous municipalities in the U.S. in 2010 according to the U.S. Census (U.S. Census 2010)

The mail survey was titled "Perceptions of Urban Forestry Employers Questionnaire." It was mailed to the two hundred most populous cities in the United States. A total of two hundred and twelve surveys were mailed as some municipalities had more than one person responsible for hiring and managing urban foresters often due to urban forestry activities occurring in more than one department.

The lack of a professional organization or network for urban foresters necessitated contacting each municipality beforehand to find who was in charge of hiring urban foresters 
and where to mail the survey. A considerable amount of time was spent on this process between August 2015 and December 2015 as it was assumed that contacting a person directly would create a sense of buy in within the individual and avoid the need for the municipality to forward the questionnaire to the correct person versus simply mailing the questionnaires to the city's human resources department or town hall. The hope being these efforts would result in an increased response rate. Every city was contacted through the phone or email. Through this direct contact and researching publicly available information on the municipality's website, a mailing address was found for every municipality.

The questionnaires were sent using a modified Dillman method (Grant 2015, Fegel 2014). This multi-step process consisted of: an introductory postcard (Appendix XIII, Figure 1) sent before the questionnaire; the questionnaire (Appendix XIV, Figure 2) with an introductory letter (Appendix XIII, Figure 3) and prepaid, return envelope; a reminder postcard (Appendix XIII, Figure 2); and (if necessary) a second questionnaire with a different reminder letter (Appendix XIII, Figure 4). Each questionnaire was numbered so that the identity of which city and the person who completed the questionnaire was protected and that no repeated mailings would occur. If a city responded to the questionnaire they were not sent a second questionnaire in the second mailing. The introductory postcard told the recipient that they had been chosen for the survey and would be receiving a questionnaire in the next several days. This first postcard was sent on the fifth of January 2016. The first questionnaire was sent with an introductory letter explaining the purpose of the questionnaire and the goals of the survey along with some definitions of the terms used in the questionnaire to avoid conflation between the professions of arboriculture and urban forestry. The first questionnaire was also sent with a 
self-addressed envelope and the appropriate postage attached so that the recipient could return the questionnaire at no cost. This first questionnaire was sent three days after the introductory postcard on January eighth. The reminder postcard thanked recipients for completing the questionnaire and if they hadn't to please take the time to do so. This was mailed the nineteenth of January. The last mailing included a duplicate questionnaire and the second letter asking the recipients again to complete the questionnaire and stressed the value of their input. This second questionnaire was sent on February first only to the municipalities from which no response had been received. All mailings were sent out as close to the beginning of the week as possible so that the recipients would receive the mailings that same week as Dillman (2009) suggests. The mailings were also organized so that everything within the envelope would be visible to the recipient upon opening in the recommended fashion (Dillman et al. 2009).

\section{Online Questionnaire}

The online questionnaire was conducted through the Survey Monkey website. This survey was opened on February second 2016. Several emails were sent out to invite professionals to complete the questionnaire online. Emails were sent to all of the members of the core research group, the entire steering committee and every state level urban forester directing them to a website (see Appendix XV, Figure 1). This website was created for the questionnaire by a colleague in the UF 2020 research group at Virginia Polytechnic Institute and State University and employers of urban foresters were encouraged to go to this website where a brief explanation of the research project as a whole and this survey were given along with the link to the Survey Monkey website where the questionnaire could be completed. The 
questionnaire sent to employers of urban foresters was nearly identical to the mail survey. The only change being to the first question that in the survey to the top two hundred most populous cities in the United States asked, "Of the following choices, which department title would be the most appropriate to describe where your urban forestry program is placed in your municipality's organizational system?" it instead asked "Of the following choices, which would be the most appropriate to describe the area of urban forestry in which you work?" to accommodate the employers that are outside the area of municipal urban forestry profession. The online survey also asked for the ZIP code and city where the respondent performs the majority of their work. There are a few other instances where the text was changed from "municipality" to "establishment" to accommodate the expectedly more diverse group of employers that would complete the online questionnaire. Despite the overall similarity between the two surveys, both were submitted separately to the Internal Review Board at West Virginia University and granted protocol exemption (Protocol number 1512926006).

\section{Perceptions of Urban Forestry Employers Questionnaire}

This survey was developed from a review of literature and in coordination with the UF 2020 research group. The questionnaire primarily uses Likert scale questions to capture employers' perceptions (Likert 1932). All other questions in the questionnaire ask for numerical values with the exception of one single question that asks, "What is the official name of the urban forestry program within your municipality?" in the mail questionnaire. This question in the online survey was changed to, "What is the ZIP code where you perform the majority of your work?" The skills, areas of knowledge, and credentials urban forestry employers were asked to rate was chosen by reviewing studies looking at the skilled desired by employers 
(McPherson 1984, Sample et al. 1999, Thompson et al. 2003) and the skills lacking in current professionals (VanDerZanden \& Reinert 2009). Other skills were identified by relevant organizations as needed or lacking (Lily 2010, SAF 2015, NUCFAC 2105). Skills were also taken from the in-person meeting of the steering committee for the UF 2020 research group during the summer of 2015 in College Park, Maryland. The UF2020 core research group performed a beta-test of the questionnaire where they reviewed the content and contributed to the list of skills used in the questionnaire based on their experience and expertise.

The questionnaire was made to resemble an "importance-performance analysis" (Martilla \& James 1977). The majority of the questionnaire was Likert scale questions, using a five-point scale, (Likert 1932) asking the employers to rate the importance of certain skills and then the frequency with which they see those same skills possessed by entry-level urban foresters that apply for jobs. This type of analysis being simple and easily understood while providing valuable insights (Martilla \& James 1977). The skills were grouped into sections: technical urban forestry, technical forestry, technical arboriculture, managerial, communication, and public administration. There were questions at the beginning of the questionnaire that asked about the size of the urban forestry program, how many new urban foresters would be hired and how many of those jobs would be filling vacancies versus how many would be newly-created positions at the municipality. This way not only would the current size of the program be measured, but also some idea of the growth of the urban forestry program would be gleaned. Employers were also asked at what salary level they anticipated the entry-level urban forestry positions would pay. The questionnaire ended with questions used to gather some demographic information about the respondent. 
There were spikes in responses with each new mailing. The majority of the responses were from the first questionnaire with seventy one responses returned from the first mailing sent in January and only nineteen from the February mailing. The nineteenth of January was the day with the most responses received at thirty three responses. Temporally, the responses were almost evenly spaced with forty six received in January and forty four received in February, but a large number of the February responses were still from the first mailing.

The physical questionnaires that were mailed to the two hundred most populous municipalities was recorded and the ratings of each skills was tested against various criteria for association. The size of the municipality and the total number of urban foresters was tested against the skills to see if there is an association (Keith O'Herrin 2013).

The Likert ratings that the respondents gave to the various skills, areas of knowledge and credentials were summarized, but they were tested for association with many explanatory variables. Just as both surveys used almost identical questionnaires, the explanatory variables that were tested for in both surveys were very similar. Both surveys used the following variables: total number of urban foresters employed at the municipality, total number of entrylevel urban foresters employed at the municipality, the number of entry-level hires anticipated in the next year, the number of these hires that will be new positions, the number of entry-level hires anticipated in the next five years, the number of these hires that will be new positions, and the anticipated salary of these new positions. The survey analysis differed from the online in that it used the explanatory variable of municipality population (found with external data) since the exact origin of the response was known for this survey. Also, the explanatory variable of coded answer of whether or not the municipality had a dedicated urban forestry division or 
section. The explanatory variables that were unique to the online survey were whether the institution of the respondent was reported to be public or private and the size of the municipality. These two variables were coded from questions at the beginning of the online questionnaire that were more specific and gave several options for the respondents to describe their employer. The public/private distinction was made by grouping all responses that reported their employer as being in some part of the government which included local, state or federal. In size of the municipality classification, the respondents who reported working for local governments were the only ones counted. The dividing point for the local municipalities was the 130,000 population level for it is at that this point that the chance the reporting local government might overlap with the mailed questionnaire of the two hundred most populous municipalities in the United States.

The responses of the mailed questionnaire were asked what the official name of the urban forestry program within their municipality was and these responses were coded for analysis. If the respondents' answer had the word tree, forest, or forestry in it then the municipality was coded for having a dedicated urban forestry division or section within the municipality's departmental organization. If there was no mention of these key words, even if they were closely related to the field of forestry or urban forestry such as horticulture or grounds management, than they were coded as not having a dedicated urban forestry section or division.

The Likert responses and the explanatory variables of how many entry-level urban forestry positions were anticipated in the next year, of these how many were anticipated to be new positions, how many entry-level positions were anticipated in the next five years, of those 
how many were anticipated to be new positions, were also recoded for analysis. These data were recoded to allow for Chi-square testing. The Likert responses were changed from a possible five responses $(1,2,3,4$, or 5$)$ to three to allow tests for association among the explanatory variables and the ratings given to the skills. This was done using Chi-square tests. If there are not enough responses to populate every possible answer combination the results can be heavily skewed by only a few responses even while the test overall is statistically significant. Three was left as three and stayed as neutral. If a respondent answer with a four or a five the answer was recoded to five and if the respondent answered one or two then it was recoded to one. The effect being that there were three possible answers: negative, neutral, or positive. The responses regarding the anticipated staffing levels were also grouped together. The responses for how many entry-level urban forester hires were anticipated were combined into three categories: zero, one, or two and more. The responses for how many of the entrylevel urban forester hires in the next year will be new positions were combined into two categories: zero and one or more. This was done to allow for testing for association using Chisquare tests. The responses for the anticipated number of new hires were grouped into categories that created groups of the requisite size for analysis. They varied by question according to what the respondents reported. The data was grouped as little as possible so to keep the original data intact as much as possible while still allowing statistical analysis. The responses for how many entry-level urban forester hires were anticipated in the next five years were combined into four categories: zero, one, two, and three or more. The responses for how many of these hires in the next five were anticipated to be new positions were combined to three categories: zero, one, and two or more. This was to account to for the extreme skewness 
of these responses where most responses were zero or one. These data were considered as ordinal after the combination as a result.

The results of both questionnaires were first tested for associations. The test between the explanatory variables and all the ratings given to the skills, areas of knowledge, and credentials were tested for associations using the Chi-square test or the Fisher's Exact test when necessary except for the explanatory variables that were comprised of continuous data. The explanatory variables that contained continuous data were population (in the mail questionnaire), the total number of urban foresters employed for both questionnaires, the total number of entry-level urban foresters for both questionnaires, and the anticipated salary for an entry-level position for both questionnaires. Logistic regressions were used to find significant associations between these continuous variables and the ratings given to the skills, areas of knowledge, and credentials.

Multiple regression analysis was performed in the event there was an association between a rating given to a skill, area of knowledge, or credential and more than one explanatory variable. This was done to determine which explanatory variable or variables exerted the most influence over the rating given. Additionally in a separate analysis, the Benjamini-Hochberg procedure was performed for all the associations found for every explanatory variable to control for false discovery (McDonald 2014). All the data was entered into Microsoft Excel before statistical analysis. The statistical analyses were performed using JMP version 12.2 and SAS 9.4 statistical software and alpha level was set to 0.05 . 


\section{Chapter 3: Results}

\section{Mail Survey}

The questionnaire mailed to the two hundred most populous municipalities in the United States resulted in a response rate of forty three percent. The majority of these returned questionnaires $(79 \%, n=72)$ were from the first group of questionnaire sent out to the municipalities in January 2016. Only twenty one percent $(n=19)$ of the questionnaires returned were from the second mailing in February 2016. Some of the questionnaires received in late February when the second mailing was being received, were from the original January mailing. We suspect that the second mailing prompted the responders to return our initial mailing, which may have slightly inflated the response rate for the first mailing.

Surveys were mailed to municipalities in 41 states. There were 9 states (Delaware, Maine, Montana, New Hampshire, North Dakota, Rhode Island, Vermont, West Virginia, and Wyoming) that did not have municipalities large enough to be included in the two hundred most populous municipalities. The three states with the highest number of responses came from Texas (10), Arizona (6), and California (6). Responses were not received from municipalities in five states (Arkansas, Hawaii, Idaho, Mississippi, and New Mexico) that were mailed surveys (see Table 2). The mean population of the municipalities that the respondents are employed by is 434,263 , median population was 237,517 , and the range was 129,195 to $2,239,558$. Every climatic region, as described by NOAA, is represented in the respondents (Karl 
\& Koss 1984). The three most common regions among the respondents were the Ohio Valley (17), the South (17), and the Southeast (13).

Sixty (66\%) of the ninety one responses reported that they had a dedicated urban forestry division at their municipality, in the open-ended response to question number one of the survey. . A majority $(63 \%, n=57)$ of the municipalities that responded reported that their activities were housed in the parks and recreation department in question number two. The second most common department reported was public works/utilities departments with sixteen respondents (17\%) activities followed by the "other" choice with nine (10\%). The remaining nine respondents' (10\%) answers were split among the remaining choices.

The survey asked respondents to rate the importance for an entry-level urban forester to possess in sixty skills and knowledge categories. The majority of the skills and knowledge in the questionnaire were given a preferable rating, that is to say, above a three which was listed as neutral in the questionnaire (Appendix I). The top ten most highly rated skills and knowledge for an entry-level urban forester to possess were: tree identification, public relations/customer service, oral communication, tree pruning and removal techniques, tree planting techniques, professional ethics, written communication, shade and street tree species selection, tree assessment and risk management, and worker safety (Table 3). This is based on the average Likert scale rating given to each skill or area of knowledge asked about. 
Table 2: The number of mail questionnaires sent and received by state

\begin{tabular}{|c|c|c|}
\hline State & Number Sent & Number Received \\
\hline Alabama & 4 & 1 \\
\hline Alaska & 1 & 1 \\
\hline Arizona & 12 & 5 \\
\hline Arkansas & 1 & 0 \\
\hline California & 45 & 6 \\
\hline Colorado & 7 & 3 \\
\hline Connecticut & 2 & 1 \\
\hline Delaware & 0 & 0 \\
\hline Florida & 13 & 3 \\
\hline Georgia & 4 & 1 \\
\hline Hawaii & 1 & 0 \\
\hline Idaho & 1 & 0 \\
\hline Illinois & 5 & 3 \\
\hline Indiana & 2 & 2 \\
\hline lowa & 2 & 1 \\
\hline Kansas & 4 & 4 \\
\hline Kentucky & 2 & 1 \\
\hline Louisiana & 3 & 2 \\
\hline Maine & 0 & 0 \\
\hline Maryland & 1 & 1 \\
\hline Massachusetts & 3 & 1 \\
\hline Michigan & 4 & 3 \\
\hline Minnesota & 2 & 2 \\
\hline Mississippi & 1 & 0 \\
\hline Missouri & 3 & 3 \\
\hline Montana & 0 & 0 \\
\hline Nebraska & 2 & 1 \\
\hline Nevada & 4 & 2 \\
\hline New Hampshire & 0 & 0 \\
\hline New Jersey & 3 & 1 \\
\hline New Mexico & 1 & 0 \\
\hline New York & 5 & 4 \\
\hline North Carolina & 7 & 4 \\
\hline North Dakota & 0 & 0 \\
\hline Ohio & 6 & 3 \\
\hline Oklahoma & 2 & 1 \\
\hline Oregon & 5 & 3 \\
\hline Pennsylvania & 2 & 2 \\
\hline Rhode Island & 1 & 0 \\
\hline South Carolina & 2 & 1 \\
\hline South Dakota & 1 & 1 \\
\hline Tennessee & 6 & 5 \\
\hline Texas & 23 & 10 \\
\hline Utah & 2 & 1 \\
\hline Vermont & 0 & 0 \\
\hline Virginia & 7 & 3 \\
\hline Washington & 7 & 3 \\
\hline West Virginia & 0 & 0 \\
\hline Wisconsin & 2 & 1 \\
\hline Wyoming & 0 & 0 \\
\hline Washington D.C. & 1 & 0 \\
\hline
\end{tabular}


Table 3: The ten highest valued urban forestry skills in response to the mailed survey.

\begin{tabular}{|c|c|c|c|c|}
\hline Skill & $\begin{array}{l}\text { Item } \\
\text { No. }\end{array}$ & Value & Prevalence & Difference \\
\hline Tree identification & 27 & 4.69 & 4.12 & 0.565 \\
\hline $\begin{array}{l}\text { Public relations/customer } \\
\text { service }\end{array}$ & 46 & 4.68 & 3.37 & 1.313 \\
\hline Oral communication & 47 & 4.68 & 3.74 & 0.944 \\
\hline $\begin{array}{l}\text { Tree pruning and removal } \\
\text { techniques }\end{array}$ & 22 & 4.67 & 3.84 & 0.823 \\
\hline Tree planting techniques & 20 & 4.65 & 3.87 & 0.786 \\
\hline Professional ethics & 59 & 4.65 & 3.57 & 1.079 \\
\hline Written communication & 45 & 4.56 & 3.61 & 0.950 \\
\hline $\begin{array}{l}\text { Shade and street tree species } \\
\text { selection }\end{array}$ & 19 & 4.55 & 3.78 & 0.767 \\
\hline $\begin{array}{l}\text { Tree assessment and risk } \\
\text { management }\end{array}$ & 34 & 4.48 & 3.17 & 1.314 \\
\hline Worker safety & 35 & 4.48 & 3.38 & 1.105 \\
\hline
\end{tabular}

The ten lowest rated skills and knowledge were (lowest to highest): urban wildlife management, federal urban forest resource policy, political science, climate science, tree climbing, water regulations, heavy equipment operation, tree support and lightning protection, hydrology/watershed management, and principles of utility management (see Table 4) 
Table 4: The ten lowest valued skills in response to the mailed survey.

\begin{tabular}{lcccc}
\hline Skill & Item No. & Value & Prevalence & Difference \\
\hline $\begin{array}{l}\text { Urban wildlife management } \\
\begin{array}{l}\text { Federal urban forest resource } \\
\text { policy }\end{array}\end{array}$ & 2 & 2.38 & 2.57 & -0.192 \\
$\begin{array}{l}\text { Political science } \\
\text { Climate science }\end{array}$ & 51 & 2.62 & 2.44 & 0.180 \\
$\begin{array}{l}\text { Tree climbing } \\
\begin{array}{l}\text { Water regulations } \\
\text { Heavy equipment operation }\end{array}\end{array}$ & 16 & 2.84 & 2.72 & 0.466 \\
$\begin{array}{l}\text { Tree support and lightning } \\
\text { protection } \\
\text { Hydrology/watershed } \\
\text { management }\end{array}$ & 36 & 2.92 & 2.72 & 0.247 \\
\begin{tabular}{l} 
Principles of utility management \\
\hline
\end{tabular} & 32 & 2.96 & 2.97 & 0.198 \\
\hline
\end{tabular}

The respondents were asked to rate the prevalence for an entry-level urban forester to possess each of the same sixty skills. Results for all skills can be found in Appendix I, and the majority of skills and knowledge were rated under three, or not prevalent in the prevalence question. The top ten most prevalent skills were: tree identification, tree planting techniques, tree pruning and removal techniques, shade and street tree species selection, computer skills/database management, oral communication, plant physiology, urban forest management principles, written communication, and insect and disease control respectively from highest rated to lowest rated (see Table 5). 
Table 5: The ten most prevalent skills in response to the mailed survey.

\begin{tabular}{lcccc}
\hline Skill & $\begin{array}{c}\text { Item } \\
\text { No. }\end{array}$ & Value & Prevalence & Difference \\
\hline Tree identification & 27 & 4.69 & 4.12 & 0.565 \\
Tree planting techniques & 20 & 4.65 & 3.87 & 0.786 \\
Tree pruning and removal techniques & 22 & 4.67 & 3.84 & 0.823 \\
Shade and street tree species selection & 19 & 4.55 & 3.78 & 0.767 \\
Computer skills/database management & 44 & 4.36 & 3.74 & 0.626 \\
Oral communication & 47 & 4.68 & 3.74 & 0.944 \\
Plant physiology & 12 & 4.06 & 3.71 & 0.343 \\
Urban forest management principles & 4 & 4.20 & 3.61 & 0.590 \\
Written communication & 45 & 4.56 & 3.61 & 0.950 \\
Insect and disease control & 18 & 4.15 & 3.58 & 0.568 \\
\hline
\end{tabular}

This was the opposite of the skills and knowledge value rating questions. The top ten most often lacking skills for entry-level urban foresters to possess from lowest rated to highest rated were: grant writing, political science, water regulations, public administration, federal urban forest resource policy, contract administration, principles of utility management, media relations, ordinance enforcement, and business management (see Table 6). 
Table 6: The ten least prevalent skills in response to the mailed survey.

\begin{tabular}{lcccc}
\hline Skill & Item No. & Value & Prevalence & Difference \\
\hline Grant writing & 58 & 3.15 & 2.24 & 0.902 \\
Political science & 51 & 2.72 & 2.25 & 0.466 \\
Water regulations & 8 & 2.97 & 2.37 & 0.597 \\
Public administration & 54 & 3.36 & 2.40 & 0.957 \\
Federal urban forest resource policy & 6 & 2.62 & 2.44 & 0.180 \\
Contract administration & 43 & 3.71 & 2.45 & 1.255 \\
Principles of utility management & 32 & 3.12 & 2.46 & 0.660 \\
Media relations & 49 & 3.47 & 2.51 & 0.960 \\
Ordinance enforcement & 57 & 3.90 & 2.51 & 1.386 \\
Business management & 39 & 3.37 & 2.52 & 0.847 \\
\hline
\end{tabular}

When comparing the value rating given to these skills and areas of knowledge to the prevalence rating, the skills with the ten smallest differences between importance and prevalence were, respectively from lowest to highest, social media/internet based media, federal urban forest resource policy, urban wildlife management, tree climbing, climate science, plant physiology, weed and vegetation control, soil science, tree inventory techniques. Urban wildlife management was the only skills or area of knowledge that had a prevalence rating higher than its value rating. While one's first impression might see these smaller differences as an exclusively positive result, which it is in several cases among these top ten listed where both the value and prevalence rating are positive, but more scrutiny is necessary. Using urban wildlife management as an example, the difference between its value and prevalence is the third smallest of all the skills or knowledge rated, but both the value and prevalence rating is 
below three, or the neutral rating, showing that it is neither prevalent among entry-level urban foresters nor is it a skill valued by employers.

The ten skills and knowledge with the greatest difference between the value rating they were given by respondents and the perceived prevalence of these skills and areas of knowledge were conflict resolution, ordinance enforcement, tree assessment and risk management, public relations/customer service, contract administration, employee supervision, community outreach/public engagement, permitting and compliance, worker safety, professional ethics. Similar scrutiny must be given to the skills and areas of knowledge with the largest discrepancies in value compared to prevalence. Some of the large differences in the two rating shows evidence of a highly valued skill or area of knowledge that employers desire but are not seeing in entry-level urban foresters like in conflict resolution or community outreach/public engagement. Other large differences exist for skills or areas of knowledge that are very valuable, but also have a positive prevalence rating (see Appendix II to VIII for all comparisons). These examples must be kept in mind when comparing these ratings (see Figure 2). 


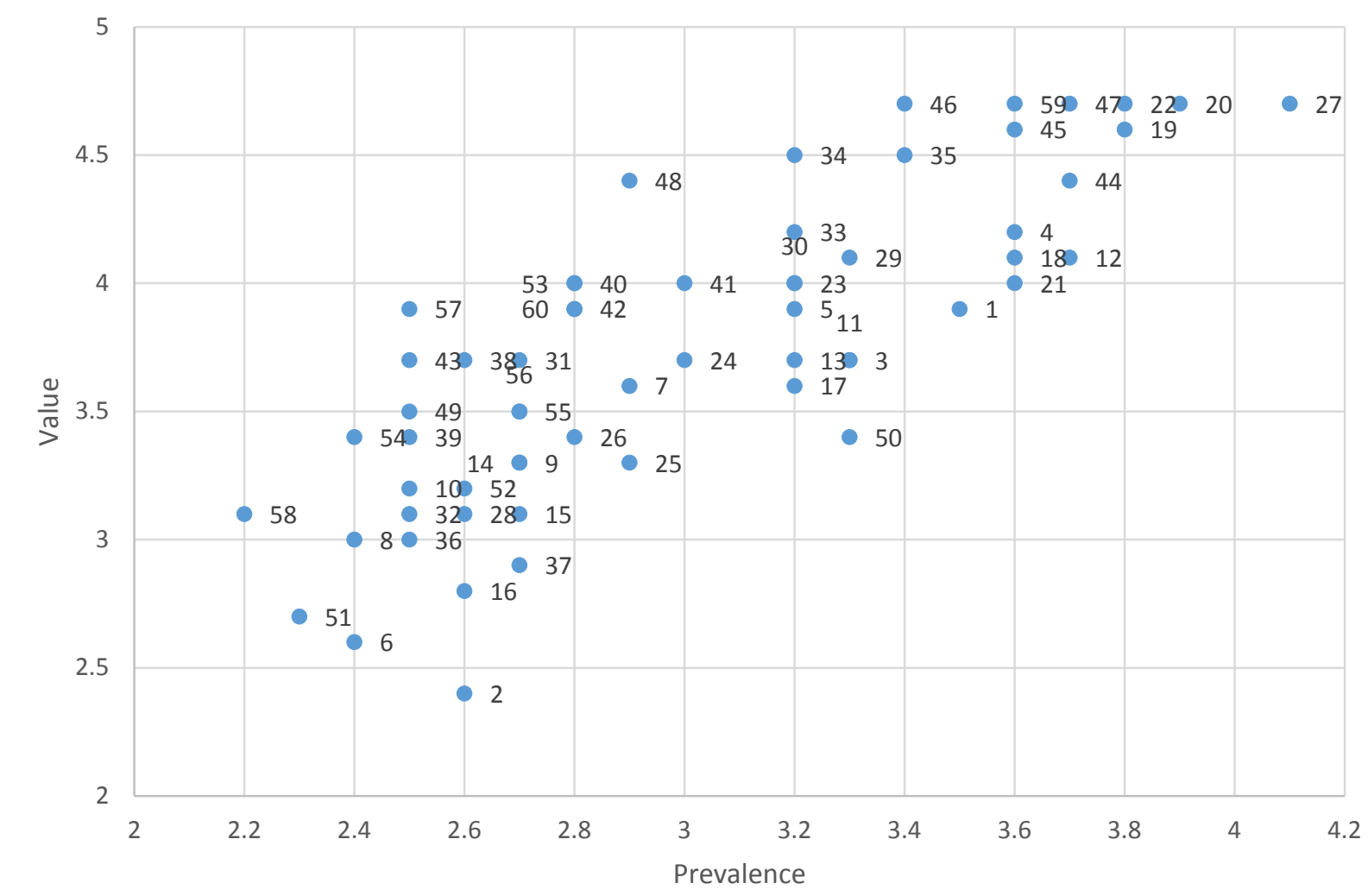

Figure 2: Plot of 60 skills and knowledge valued by employers (Value) in an entry level urban foresters compared the rating of the same skills and knowledge possessed (Prevalence) in new hires of entry level urban forester. Responses are summarized from the mail questionnaire. Three value being neutral.

Using the criteria that the rating for a skill or area of knowledge has to be greater than three in prevalence to be satisfactory and greater than three in value to be relevant twenty six skills or areas of knowledge (43\%) pass this standard that is made it into the number two quadrant (see Figure 1 and Table 7). There are seven skills or areas of knowledge (12\%) that fall into the category of not being present in entry-level urban foresters, but also not valued by employers which makes their low prevalence rating irrelevant. This group of skills with low value and low prevalence fall into the number three quadrant. The largest group of skills and 
knowledge are the twenty seven (45\%) that clear the greater-than-three value criterion, but fall below a three rating for prevalence, or skills that employers value that entry-level urban foresters do not typically possess. These skills that employers want, but are not encountering in entry-level foresters fall into quadrant number one. No skills fell into quadrant number four where the skills are prevalent, but not valued. 
Table 7: Quadrant summary of mail responses

\begin{tabular}{|c|c|c|c|c|c|c|c|c|c|c|c|}
\hline $\begin{array}{l}\text { Item } \\
\text { No. }\end{array}$ & $\begin{array}{l}\text { Urban } \\
\text { Forestry }\end{array}$ & Quadrant & Difference & $\begin{array}{l}\text { Item } \\
\text { No. }\end{array}$ & Forestry & Quadrant & Difference & $\begin{array}{l}\text { Item } \\
\text { No. }\end{array}$ & Arboriculture & Quadrant & Difference \\
\hline 1 & $\begin{array}{c}\text { Tree } \\
\text { inventor } \\
y \\
\text { techniqu }\end{array}$ & 2 & 0.396 & 11 & $\begin{array}{c}\text { Soil } \\
\text { Science }\end{array}$ & 2 & 0.385 & 18 & $\begin{array}{l}\text { Insect and } \\
\text { disease } \\
\text { control }\end{array}$ & 2 & 0.568 \\
\hline 2 & $\begin{array}{l}\text { Urban } \\
\text { wildlife } \\
\text { manage } \\
\text { ment }\end{array}$ & 3 & -0.192 & 12 & $\begin{array}{c}\text { Plant } \\
\text { physiolo } \\
\text { gy }\end{array}$ & 2 & 0.343 & 19 & $\begin{array}{c}\text { Shade and } \\
\text { street tree } \\
\text { species } \\
\text { selection }\end{array}$ & 2 & 0.767 \\
\hline 3 & $\begin{array}{l}\text { GIS and } \\
\text { geospati } \\
\text { al } \\
\text { technolo }\end{array}$ & 2 & 0.439 & 13 & Ecology & 2 & 0.515 & 20 & $\begin{array}{l}\text { Tree planting } \\
\text { techniques }\end{array}$ & 2 & 0.786 \\
\hline 4 & $\begin{array}{c}\text { Urban } \\
\text { forest } \\
\text { manage } \\
\text { ment }\end{array}$ & 2 & 0.590 & 14 & $\begin{array}{c}\text { Park } \\
\text { administ } \\
\text { ration } / \mathrm{m} \\
\text { anagem }\end{array}$ & 1 & 0.535 & 21 & $\begin{array}{c}\text { Tree nutrition } \\
\text { and } \\
\text { fertilization }\end{array}$ & 2 & 0.446 \\
\hline 5 & $\begin{array}{l}\text { Municip } \\
\text { al urban } \\
\text { forest } \\
\text { resource }\end{array}$ & 2 & 0.637 & 15 & $\begin{array}{l}\text { Hydrolog } \\
\text { y/Water } \\
\text { shed } \\
\text { manage }\end{array}$ & 1 & 0.424 & 22 & $\begin{array}{l}\text { Tree pruning } \\
\text { and removal } \\
\text { techniques }\end{array}$ & 2 & 0.823 \\
\hline 6 & $\begin{array}{l}\text { Federal } \\
\text { urban } \\
\text { forest } \\
\text { resource }\end{array}$ & 3 & 0.180 & 16 & $\begin{array}{l}\text { Climate } \\
\text { science }\end{array}$ & 3 & 0.247 & 23 & $\begin{array}{c}\text { Root } \\
\text { management } \\
\text { and root } \\
\text { pruning }\end{array}$ & 2 & 0.829 \\
\hline 7 & $\begin{array}{l}\text { Site plan } \\
\text { review }\end{array}$ & 1 & 0.717 & 17 & $\begin{array}{l}\text { Weed } \\
\text { and } \\
\text { vegetati } \\
\text { on }\end{array}$ & 2 & 0.371 & 24 & $\begin{array}{c}\text { Water } \\
\text { management } \\
\text { and irrigation }\end{array}$ & 1 & 0.682 \\
\hline 8 & $\begin{array}{c}\text { Water } \\
\text { regulatio } \\
\text { ns }\end{array}$ & 3 & 0.597 & & & & & 25 & $\begin{array}{l}\text { Landscape } \\
\text { construction }\end{array}$ & 1 & 0.401 \\
\hline 9 & $\begin{array}{c}\text { Green } \\
\text { infrastru } \\
\text { cture } \\
\text { planning }\end{array}$ & 1 & 0.615 & & & & & 26 & $\begin{array}{c}\text { Landscape } \\
\text { management }\end{array}$ & 1 & 0.552 \\
\hline \multirow[t]{5}{*}{10} & $\begin{array}{c}\text { Resilienc } \\
y \\
\text { planning } \\
\text { /disaster }\end{array}$ & 1 & 0.627 & & & & & 27 & $\begin{array}{c}\text { Tree } \\
\text { identification }\end{array}$ & 2 & 0.565 \\
\hline & & & & & & & & 28 & $\begin{array}{c}\text { Tree support } \\
\text { and lightning } \\
\text { protection }\end{array}$ & 1 & 0.430 \\
\hline & & & & & & & & 29 & $\begin{array}{c}\text { Tree disorder } \\
\text { diagnostics }\end{array}$ & 2 & 0.810 \\
\hline & & & & & & & & 30 & $\begin{array}{c}\text { Plant } \\
\text { materials/nur } \\
\text { sery stock } \\
\text { quality }\end{array}$ & 2 & 0.865 \\
\hline & & & & & & & & 31 & Tree appraisal & 1 & 0.998 \\
\hline
\end{tabular}


33

Tree preservation

2

0.997

Tree assessment and risk management

35 Worker safety

Heavy equipment operation 
Table 7: Continued

\begin{tabular}{|c|c|c|c|c|c|c|c|c|c|c|c|}
\hline $\begin{array}{l}\text { Item } \\
\text { No. }\end{array}$ & Managerial & Quadrant & Difference & $\begin{array}{l}\text { Item } \\
\text { No. }\end{array}$ & Communication & Quadrant & Difference & $\begin{array}{l}\text { Item } \\
\text { No. }\end{array}$ & $\begin{array}{c}\text { Public } \\
\text { Administration }\end{array}$ & Quadrant & Difference \\
\hline 38 & Budgeting & 1 & 1.060 & 45 & $\begin{array}{c}\text { Written } \\
\text { communication }\end{array}$ & 2 & 0.950 & 51 & $\begin{array}{l}\text { Political } \\
\text { science }\end{array}$ & 3 & 0.466 \\
\hline 39 & $\begin{array}{l}\text { Business } \\
\text { managem } \\
\text { ent }\end{array}$ & 1 & 0.847 & 46 & $\begin{array}{c}\text { Public } \\
\text { relations/custo } \\
\text { mer service }\end{array}$ & 2 & 1.313 & 52 & $\begin{array}{l}\text { Land use } \\
\text { planning }\end{array}$ & 1 & 0.658 \\
\hline 40 & $\begin{array}{c}\text { Employee } \\
\text { supervisio } \\
\mathrm{n}\end{array}$ & 1 & 1.228 & 47 & $\begin{array}{c}\text { Oral } \\
\text { communication }\end{array}$ & 2 & 0.944 & 53 & $\begin{array}{l}\text { Community } \\
\text { outreach/ } \\
\text { public } \\
\text { engagement }\end{array}$ & 1 & 1.137 \\
\hline 41 & $\begin{array}{l}\text { Training/t } \\
\text { eaching }\end{array}$ & 1 & 0.930 & 48 & $\begin{array}{l}\text { Conflict } \\
\text { resolution }\end{array}$ & 1 & 1.540 & 54 & $\begin{array}{c}\text { Public } \\
\text { administration }\end{array}$ & 1 & 0.957 \\
\hline 42 & $\begin{array}{l}\text { Project } \\
\text { managem } \\
\text { ent }\end{array}$ & 1 & 1.020 & 49 & Media relations & 1 & 0.960 & 55 & $\begin{array}{l}\text { Volunteer } \\
\text { organization }\end{array}$ & 1 & 0.846 \\
\hline 43 & $\begin{array}{l}\text { Contract } \\
\text { administr } \\
\text { ation }\end{array}$ & 1 & 1.255 & 50 & $\begin{array}{c}\text { Social } \\
\text { media/internet } \\
\text { based media }\end{array}$ & 2 & 0.113 & 56 & $\begin{array}{l}\text { Multicultural } \\
\text { competency }\end{array}$ & 1 & 0.745 \\
\hline \multirow[t]{4}{*}{44} & $\begin{array}{l}\text { Computer } \\
\text { skills/ } \\
\text { database } \\
\text { managem }\end{array}$ & 2 & 0.626 & & & & & 57 & $\begin{array}{l}\text { Ordinance } \\
\text { enforcement }\end{array}$ & 1 & 1.386 \\
\hline & & & & & & & & 58 & Grant writing & 1 & 0.902 \\
\hline & & & & & & & & 59 & $\begin{array}{l}\text { Professional } \\
\text { ethics }\end{array}$ & 2 & 1.079 \\
\hline & & & & & & & & 60 & $\begin{array}{l}\text { Permitting } \\
\quad \text { and } \\
\text { compliance }\end{array}$ & 1 & 1.109 \\
\hline
\end{tabular}

A four year college degree was the highest level of educational attainment that the employers gave a positive value. The top three highest rated educational backgrounds for entry level urban foresters from highest to lowest was urban forestry (4.58), arboriculture (4.32), and forestry (4.23). All levels of practical or internship experience received a positive rating and this rating increased with the cumulative time of the experience. The top three 
credentials were the International Society of Arboriculture Certified Arborist (4.34), commercial applicator pesticide license (3.39), and International Society of Arboriculture Municipal Specialist (3.37). The only other credentials to get a rating above neutral were a commercial driver's license (3.18), Society of American Foresters Accredited Urban Forestry Degree (3.14), and Society of American Foresters Accredited Forestry Degree (3.01). Employers in the mailed questionnaire gave a university certificate a positive rating (3.45) on average.

The departments within the municipalities which the respondents worked varied in size. The mean size of the departments, that is the total number of urban foresters employed by the municipality, was 4.16 , but the median was one and a range of ninety four. The mean of entry level urban foresters the municipalities employed was 2.76 with a median of zero and a range of seventy three. The majority of municipalities $(76 \%, n=69)$ reported that they did not plan on hiring any entry-level urban foresters in the next year (Appendix XVII, Figure 1). Sixteen respondents (17.6\%) anticipating hiring one person in the next year. Only a small minority (3\%, $\mathrm{n}=6$ ) planned to hire three or more entry-level urban foresters in the next year. Of these new positions almost all $(91.1 \%, n=82)$ will not be new positions, but hires to fill vacancies with just eight respondents (8.89\%) anticipating these hires will be for newly created positions. When asked how many entry-level urban foresters the respondents anticipated hiring in the next five years the numbers were still quite low. The amount of respondents that answered both zero or one were equal at thirty three response each (37\%), which means more hires than in the next year, but still low. Thirteen respondents (14.6\%) anticipated hiring two entry-level urban foresters in the next five years. Only about eleven percent $(n=10)$ of respondents reported they anticipated hiring three or more entry-level urban foresters in the next five years. Of these 
positions, the majority $(62.2 \%, n=56)$ will not be new positions. Twenty four respondents (26.7\%) anticipated there being one new position created in the next five years and just ten (11.1\%) anticipated two or more new positions in the next five years. The top three most common anticipated pay ranges reported were $\$ 40,000$ to $\$ 44,999(18.7 \%, n=17), \$ 45,000$ to $\$ 49,999(16.5 \%, n=15)$, and $\$ 30,000$ to $\$ 34,999(13.2 \%, n=12)$.

The majority of respondents were male with seventy responses (78\%) and only twenty (22\%) female and one respondent left this question blank. The mean age of the respondents was 50.0 years old. The median age was fifty two and a standard deviation of 9.85. The most common level of educational attainment for the respondents was a four year degree at forty four responses (49\%). The second most common level was a graduate degree at thirty six (40\%). Five respondents (6\%) had an associates or two year degree and four (4\%) were at the level of a high school diploma. No respondents had a doctorate degree. The three most common educational backgrounds for the respondents were forestry $(28 \%, n=23)$, horticulture $(19 \%, n=15)$, and urban forestry $(16 \%, n=13)$. The least common educational backgrounds, all with just one (1\%) respondents each, were arboriculture, urban planning, recreation management, and geography. Ten responses (11\%) were blank or invalid.

The respondents' mean number of employees they currently manage was 32.0 and a median of fifteen with a standard deviation of 48.0. The mean number of years of experience for the respondent in urban forestry was 18.5 years with a standard deviation of 11.8 . The median was 19.5 years. The range was 42 years. The mean of the number of years working as a manager in urban forestry was 13.6 with a standard deviation of 10.7 . The range was thirty five. The median was ten. 


\section{Online Questionnaire Results}

The online questionnaire was open for twenty nine days and received a total of 325

responses. The majority of responses were received within the nine days of the first email sent

(Figure 3). A second surge of responses came within eight days of the second email. A third surge came within seventeen days of opening the questionnaire. Fifteen responses were excluded because they came from outside the United States and thus outside the scope of the survey.

\section{First: $2 / 1 / 2016$ Zoom: $1 / 31 / 2016$ to $2 / 29 / 2016$}

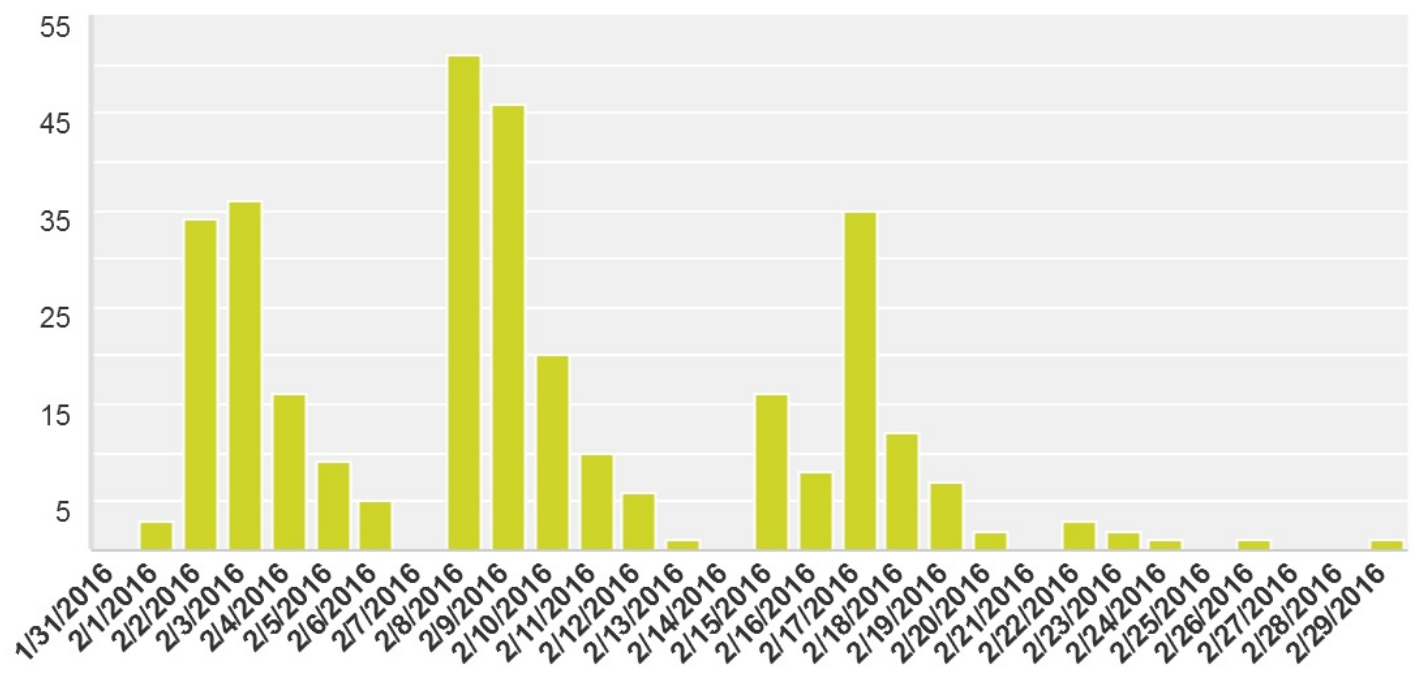

Figure 3: Number of online responses received by day.

The online questionnaire was designed to supplement the mail survey by capturing data that was being missed by only surveying the two hundred most populous municipalities in the United States. Given this fact, the stated area of employment within the field of urban forestry 
of the respondents (Question 2) was particularly exciting. The large majority of respondents $(80.2 \%, n=246)$ were employed in areas different than those surveyed in the mail questionnaire. The top three areas of employment, highest to lowest, were: local government, population of 59,999 or less, $(21.1 \%, n=68)$; tree care companies $(12.7 \%, n=41)$; and local government, population of 60,000 to $129,999,(10.2 \%, n=33)$. It is known that, according to current U.S. Census estimates (U.S. Census 2010), the least populous municipality in the United States surveyed in the mail questionnaire has population of over 130,000 . Using this same information, only a minority of respondents could potentially overlap with the mail questionnaire $(19.8 \%, \mathrm{n}=61)$.

All of the NOAA climatic regions were represented in the respondents. The most common was the Ohio Valley climatic region $(27.7 \%, n=86)$, the second most was the Southeast climatic region $(17.4 \%, n=54)$ and third most was the Northeast climatic region $(14.5 \%, n=45)$. Responses from all states and Washington D.C. were received except from the following twelve states: Alabama, Alaska, Arkansas, Delaware, Kansas, Maine, Mississippi, Nevada, New Hampshire, North Dakota, Oklahoma, and Vermont (see Table 8). The three states with the most respondents were Illinois $(15.5 \%, n=48)$, Virginia $(12.9 \%, n=40)$, and Maryland $(5.16 \%$, $\mathrm{n}=16)$. A portion $(12.3 \%, \mathrm{n}=38)$ of the respondents did not give information regarding their location. All locations were found by the ZIP codes and municipality names provided by the respondents. 
Table 8: The number of online responses received by state

\begin{tabular}{|c|c|c|c|}
\hline State & No. Received & State & No. Received \\
\hline Alabama & 0 & Nebraska & 6 \\
\hline Alaska & 0 & Nevada & 0 \\
\hline Arizona & 7 & New Hampshire & 0 \\
\hline Arkansas & 0 & New Jersey & 1 \\
\hline California & 9 & New Mexico & 1 \\
\hline Colorado & 15 & New York & 15 \\
\hline Connecticut & 1 & North Carolina & 2 \\
\hline Delaware & 0 & North Dakota & 0 \\
\hline Florida & 1 & Ohio & 10 \\
\hline Georgia & 3 & Oklahoma & 0 \\
\hline Hawaii & 1 & Oregon & 3 \\
\hline Idaho & 3 & Pennsylvania & 10 \\
\hline Illinois & 48 & Rhode Island & 1 \\
\hline Indiana & 13 & South Carolina & 1 \\
\hline lowa & 5 & South Dakota & 2 \\
\hline Kansas & 0 & Tennessee & 2 \\
\hline Kentucky & 1 & Texas & 3 \\
\hline Louisiana & 1 & Utah & 1 \\
\hline Maine & 0 & Vermont & 0 \\
\hline Maryland & 16 & Virginia & 40 \\
\hline Massachusetts & 1 & Washington & 13 \\
\hline Michigan & 6 & West Virginia & 10 \\
\hline Minnesota & 1 & Wisconsin & 5 \\
\hline Mississippi & 0 & Wyoming & 3 \\
\hline Missouri & 2 & Washington D.C. & 6 \\
\hline Montana & 3 & & \\
\hline
\end{tabular}

The majority of the respondents were employed by public institutions $(61.7 \%, n=190)$ with the smaller portion $(38.3 \%, n=118)$ of respondents employed by private institutions that is all other categories beyond public institutions. Of the respondents that were employed by public institutions, the majority $(62.4 \%, n=98)$ were employed by small municipalities and the minority $(37.6 \%, n=59)$ were employed by large municipalities (that is municipalities large enough to potentially overlap with the mail questionnaire).

The mean number of urban foresters employed at the respondent's institution, with two outliers (more than ten standard deviations) excluded, was 9.72 and a median of three. 
The range was two hundred. The mean total number of entry-level urban foresters was 4.82 and a median of one. The range was one hundred and three.

The respondents anticipated that their institutions would be hiring an average, or mean, of 1.72 entry-level urban foresters in the next year. The median value was zero with a range of forty five. The majority of respondents $(55.3 \%, n=146)$ did not anticipate hiring an entry-level forester in the next year (Appendix XVII, Figure 2). Fifty one (19.3\%) respondents anticipated hiring one entry-level forester in the next year and sixty seven (25.4\%) anticipated hiring more than two. Of these positions, the mean number of anticipated new entry-level positions was 0.829 with a median of zero and a range of twenty five. Almost three quarters of respondents (72.8\%, $\mathrm{n}=182)$ anticipated these positions to not be newly created positions, but to hire vacancies. Sixty eight respondents (27.2\%) anticipated hiring one or more entry-level urban foresters to newly created positions. The mean number of entry-level urban foresters the respondents anticipated hiring in the next five years was 5.14. The median value was 1 and had a range of one hundred and twenty. Eighty one respondents (31.0\%) anticipated hiring zero entry-level foresters in the next five years, fifty seven (21.8\%) anticipated hiring one, forty three (16.5\%) anticipated hiring two, and eighty (30.7\%) anticipated hiring three or more. The mean of anticipated newly created positions in the next five years among these hires was 2.48 and had a median of zero. About half of the respondents $(51.6 \%, n=130)$ anticipating zero of the hires would be for new positions, forty three (17.1\%) anticipated one of the hires would be to a newly created position, and seventy nine (31.3\%) reported they anticipated two more of the hires would be to newly created positions. The range was eighty. The top three anticipated 
pay range for the entry-level positions were $\$ 30,000$ to $\$ 34,999(15.2 \%, n=47), \$ 40,000$ to $\$ 44,999(15.2 \%, n=47)$, and $\$ 35,000$ to $\$ 39,999(13.2 \%, n=41)$.

The top ten highest valued skills or areas of knowledge were: tree identification, oral communication, public relations/customer service, tree planting techniques, tree pruning and removal techniques, shade and street tree species selection, professional ethics, worker safety, written communication, tree assessment and risk management from highest rated to lowest respectively (Table 9).

Table 9: The ten highest valued skills in response to the online survey.

\begin{tabular}{lcccc}
\hline Skills & Item No. & Value & Prevalence & Difference \\
\hline Tree identification & 27 & 4.77 & 3.93 & 0.84 \\
Oral communication & 47 & 4.7 & 3.38 & 1.32 \\
Public relations/customer service & 46 & 4.68 & 2.99 & 1.69 \\
Tree planting techniques & 20 & 4.61 & 3.67 & 0.94 \\
Tree pruning and removal techniques & 22 & 4.61 & 3.44 & 1.17 \\
Shade and street tree species selection & 19 & 4.52 & 3.49 & 1.03 \\
Professional ethics & 59 & 4.51 & 3.22 & 1.29 \\
Worker safety & 35 & 4.48 & 3.11 & 1.37 \\
Written communication & 45 & 4.43 & 3.18 & 1.25 \\
Tree assessment and risk management & 34 & 4.39 & 2.86 & 1.53 \\
\hline
\end{tabular}

Similar to the mailed questionnaire most of the skills were rated favorable with only eight skills or areas of knowledge rated under three, or neutral. The ten lowest rated from lowest to highest were urban wildlife management, political science, federal urban forest 
resource policy, grant writing, climate science, heavy equipment operation, water regulations, park administration/management, business management, and tree climbing (Table 10).

Table 10: The ten least valued skills in response to the online survey.

\begin{tabular}{lcccc}
\hline Skills & Item No. & Value & Prevalence & Difference \\
\hline Urban wildlife management & 2 & 2.5 & 2.58 & -0.08 \\
Political science & 51 & 2.52 & 2.21 & 0.31 \\
Federal urban forest resource policy & 6 & 2.63 & 2.38 & 0.25 \\
Grant writing & 58 & 2.82 & 2.05 & 0.77 \\
Climate science & 16 & 2.88 & 2.59 & 0.29 \\
Heavy equipment operation & 36 & 2.92 & 2.24 & 0.68 \\
Water regulations & 8 & 2.95 & 2.4 & 0.55 \\
Park administration/management & 14 & 2.99 & 2.61 & 0.38 \\
Business management & 39 & 3.04 & 2.13 & 0.91 \\
Hydrology/Watershed management & 15 & 3.06 & 2.59 & 0.47 \\
\hline
\end{tabular}

The ten skills or knowledge areas with the highest prevalence ratings, from highest to lowest, were: tree identification, computer skills/database management, tree planting techniques, plant physiology, shade and street tree species selection, tree pruning and removal techniques, tree inventory techniques, oral communication, ecology, urban forest management principles (Table 11). 
Table 11: The ten most prevalent skills in response to the online survey.

\begin{tabular}{lcccc}
\hline Skills & Items & Value & Prevalence & Difference \\
\hline Tree identification & 27 & 4.77 & 3.93 & 0.84 \\
Computer skills/database management & 44 & 4.18 & 3.69 & 0.49 \\
Tree planting techniques & 20 & 4.61 & 3.67 & 0.94 \\
Plant physiology & 12 & 4.32 & 3.56 & 0.76 \\
Shade and street tree species selection & 19 & 4.52 & 3.49 & 1.03 \\
Tree pruning and removal techniques & 22 & 4.61 & 3.44 & 1.17 \\
Tree inventory techniques & 1 & 3.95 & 3.4 & 0.55 \\
Oral communication & 47 & 4.7 & 3.38 & 1.32 \\
Ecology & 13 & 3.79 & 3.37 & 0.42 \\
Urban forest management principles & 4 & 4.18 & 3.28 & 0.9 \\
\hline
\end{tabular}

Of all the skills and areas of knowledge rated, only eighteen received a prevalence rating higher than neutral. The ten with the lowest prevalence, lowest to highest, were: grant writing, contract administration, budgeting, business management, media relations, political science, heavy equipment operation, public administration, ordinance enforcement, employee supervision (Table 12). 
Table 12: The ten least prevalent skills in response to the online survey.

\begin{tabular}{lcccc}
\hline Skills & Item No. & Value & Prevalence & Difference \\
\hline Grant writing & 58 & 2.82 & 2.05 & 0.77 \\
Contract administration & 43 & 3.26 & 2.11 & 1.15 \\
Budgeting & 38 & 3.15 & 2.12 & 1.03 \\
Business management & 39 & 3.04 & 2.13 & 0.91 \\
Media relations & 49 & 3.25 & 2.19 & 1.06 \\
Political science & 51 & 2.52 & 2.21 & 0.31 \\
Heavy equipment operation & 36 & 2.92 & 2.24 & 0.68 \\
Public administration & 54 & 3.1 & 2.27 & 0.83 \\
Ordinance enforcement & 57 & 3.32 & 2.3 & 1.02 \\
Employee supervision & 40 & 3.34 & 2.31 & 1.03 \\
\hline
\end{tabular}

The skills with the largest differences between the value rating they were given and the prevalence rating they were given from highest to lowest were: conflict resolution, public relations/customer service, tree assessment and risk management, worker safety, oral communication, community outreach/public engagement, professional ethics, root management and root pruning, written communication, tree disorder diagnostics. Similar to the mail questionnaire, some of the skills and areas of knowledge that have a large difference between their value rating and their prevalence rating are still in positive for both, for example written communication and professional ethics. Appropriate scrutiny has to be given to these numbers (see Figure 3). The skills with the smallest difference between their value and prevalence rating, lowest to highest, were: social media/internet based media, urban wildlife management, federal urban forest resource policy, climate science, political science, park 
administration/management, ecology, hydrology/watershed management, computer skills/database management, and tree climbing. Again, urban wildlife management had a prevalence rating higher than its value rating and in the online questionnaire the area of knowledge social media/internet based media also joined this category. The skills ratings from the online responses were grouped into the same quadrants as the previous table of mail responses (Table 13). Thirty four skills (57\%) fell into quadrant one. Eighteen skills (30\%) fell into quadrant two. Eight skills (13\%) fell into quadrant three.

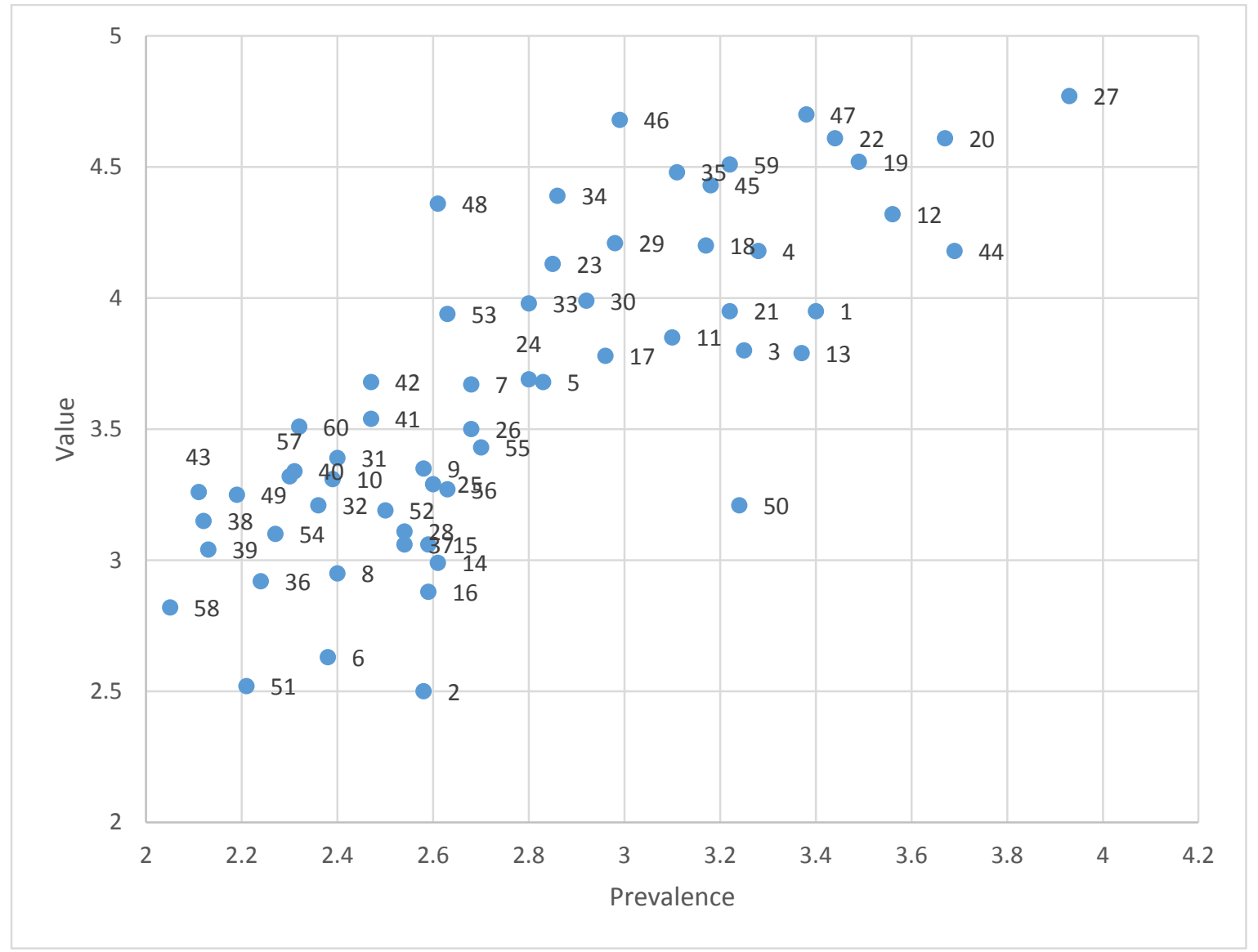

Figure 4: Plot of 60 skills and knowledge valued by employers (Value) in an entry level urban foresters compared the rating of the same skills and knowledge possessed (Prevalence) in new hires of entry level urban forester. Responses are summarized from the online questionnaire. Value greater than three (neutral) suggests a skill is values and prevalence greater than three suggests new hires possess the given skill. 
Table 13: Quadrant summary of online responses

\begin{tabular}{|c|c|c|c|c|c|c|c|c|c|c|c|}
\hline $\begin{array}{l}\text { Item } \\
\text { No. }\end{array}$ & $\begin{array}{l}\text { Urban } \\
\text { Forestry }\end{array}$ & Quadrant & Difference & $\begin{array}{l}\text { Item } \\
\text { No. }\end{array}$ & Forestry & Quadrant & Difference & $\begin{array}{l}\text { Item } \\
\text { No. }\end{array}$ & Arboriculture & Quadrant & Difference \\
\hline 1 & $\begin{array}{c}\text { Tree } \\
\text { inventor } \\
y \\
\text { techniqu }\end{array}$ & 2 & 0.396 & 11 & $\begin{array}{c}\text { Soil } \\
\text { Science }\end{array}$ & 2 & 0.385 & 18 & $\begin{array}{l}\text { Insect and } \\
\text { disease } \\
\text { control }\end{array}$ & 2 & 0.568 \\
\hline 2 & $\begin{array}{l}\text { Urban } \\
\text { wildlife } \\
\text { manage } \\
\text { ment }\end{array}$ & 3 & -0.192 & 12 & $\begin{array}{c}\text { Plant } \\
\text { physiolo } \\
\text { gy }\end{array}$ & 2 & 0.343 & 19 & $\begin{array}{c}\text { Shade and } \\
\text { street tree } \\
\text { species } \\
\text { selection }\end{array}$ & 2 & 0.767 \\
\hline 3 & $\begin{array}{l}\text { GIS and } \\
\text { geospati } \\
\text { al } \\
\text { technolo }\end{array}$ & 2 & 0.439 & 13 & Ecology & 2 & 0.515 & 20 & $\begin{array}{l}\text { Tree planting } \\
\text { techniques }\end{array}$ & 2 & 0.786 \\
\hline 4 & $\begin{array}{c}\text { Urban } \\
\text { forest } \\
\text { manage } \\
\text { ment }\end{array}$ & 2 & 0.590 & 14 & $\begin{array}{c}\text { Park } \\
\text { administ } \\
\text { ration } / \mathrm{m} \\
\text { anagem }\end{array}$ & 1 & 0.535 & 21 & $\begin{array}{c}\text { Tree nutrition } \\
\text { and } \\
\text { fertilization }\end{array}$ & 2 & 0.446 \\
\hline 5 & $\begin{array}{l}\text { Municip } \\
\text { al urban } \\
\text { forest } \\
\text { resource }\end{array}$ & 2 & 0.637 & 15 & $\begin{array}{l}\text { Hydrolog } \\
\text { y/Water } \\
\text { shed } \\
\text { manage }\end{array}$ & 1 & 0.424 & 22 & $\begin{array}{l}\text { Tree pruning } \\
\text { and removal } \\
\text { techniques }\end{array}$ & 2 & 0.823 \\
\hline 6 & $\begin{array}{l}\text { Federal } \\
\text { urban } \\
\text { forest } \\
\text { resource }\end{array}$ & 3 & 0.180 & 16 & $\begin{array}{l}\text { Climate } \\
\text { science }\end{array}$ & 3 & 0.247 & 23 & $\begin{array}{c}\text { Root } \\
\text { management } \\
\text { and root } \\
\text { pruning }\end{array}$ & 2 & 0.829 \\
\hline 7 & $\begin{array}{l}\text { Site plan } \\
\text { review }\end{array}$ & 1 & 0.717 & 17 & $\begin{array}{l}\text { Weed } \\
\text { and } \\
\text { vegetati } \\
\text { on }\end{array}$ & 2 & 0.371 & 24 & $\begin{array}{c}\text { Water } \\
\text { management } \\
\text { and irrigation }\end{array}$ & 1 & 0.682 \\
\hline 8 & $\begin{array}{c}\text { Water } \\
\text { regulatio } \\
\text { ns }\end{array}$ & 3 & 0.597 & & & & & 25 & $\begin{array}{l}\text { Landscape } \\
\text { construction }\end{array}$ & 1 & 0.401 \\
\hline 9 & $\begin{array}{c}\text { Green } \\
\text { infrastru } \\
\text { cture } \\
\text { planning }\end{array}$ & 1 & 0.615 & & & & & 26 & $\begin{array}{c}\text { Landscape } \\
\text { management }\end{array}$ & 1 & 0.552 \\
\hline \multirow[t]{5}{*}{10} & $\begin{array}{c}\text { Resilienc } \\
y \\
\text { planning } \\
\text { /disaster }\end{array}$ & 1 & 0.627 & & & & & 27 & $\begin{array}{c}\text { Tree } \\
\text { identification }\end{array}$ & 2 & 0.565 \\
\hline & & & & & & & & 28 & $\begin{array}{c}\text { Tree support } \\
\text { and lightning } \\
\text { protection }\end{array}$ & 1 & 0.430 \\
\hline & & & & & & & & 29 & $\begin{array}{c}\text { Tree disorder } \\
\text { diagnostics }\end{array}$ & 2 & 0.810 \\
\hline & & & & & & & & 30 & $\begin{array}{c}\text { Plant } \\
\text { materials/nur } \\
\text { sery stock } \\
\text { quality }\end{array}$ & 2 & 0.865 \\
\hline & & & & & & & & 31 & Tree appraisal & 1 & 0.998 \\
\hline
\end{tabular}


33

Tree preservation

Tree assessment and risk management

35 Worker safety

Heavy equipment operation 
Table 13: Continued

\begin{tabular}{|c|c|c|c|c|c|c|c|c|c|c|c|}
\hline $\begin{array}{l}\text { Item } \\
\text { No. }\end{array}$ & Managerial & Quadrant & Difference & $\begin{array}{l}\text { Item } \\
\text { No. }\end{array}$ & Communication & Quadrant & Difference & $\begin{array}{l}\text { Item } \\
\text { No. }\end{array}$ & $\begin{array}{c}\text { Public } \\
\text { Administration }\end{array}$ & Quadrant & Difference \\
\hline 38 & Budgeting & 1 & 1.03 & 45 & $\begin{array}{c}\text { Written } \\
\text { communication }\end{array}$ & 2 & 1.25 & 51 & $\begin{array}{l}\text { Political } \\
\text { science }\end{array}$ & 3 & 0.31 \\
\hline 39 & $\begin{array}{l}\text { Business } \\
\text { managem } \\
\text { ent }\end{array}$ & 1 & 0.91 & 46 & $\begin{array}{c}\text { Public } \\
\text { relations/custo } \\
\text { mer service }\end{array}$ & 1 & 1.69 & 52 & $\begin{array}{l}\text { Land use } \\
\text { planning }\end{array}$ & 1 & 0.69 \\
\hline 40 & $\begin{array}{c}\text { Employee } \\
\text { supervisio } \\
n\end{array}$ & 1 & 1.03 & 47 & $\begin{array}{c}\text { Oral } \\
\text { communication }\end{array}$ & 2 & 1.32 & 53 & $\begin{array}{l}\text { Community } \\
\text { outreach/ } \\
\text { public } \\
\text { engagement }\end{array}$ & 1 & 1.31 \\
\hline 41 & $\begin{array}{l}\text { Training/t } \\
\text { eaching }\end{array}$ & 1 & 1.07 & 48 & $\begin{array}{l}\text { Conflict } \\
\text { resolution }\end{array}$ & 1 & 1.75 & 54 & $\begin{array}{c}\text { Public } \\
\text { administration }\end{array}$ & 1 & 0.83 \\
\hline 42 & $\begin{array}{c}\text { Project } \\
\text { managem } \\
\text { ent }\end{array}$ & 1 & 1.21 & 49 & Media relations & 1 & 1.06 & 55 & $\begin{array}{l}\text { Volunteer } \\
\text { organization }\end{array}$ & 1 & 0.73 \\
\hline 43 & $\begin{array}{l}\text { Contract } \\
\text { administr } \\
\text { ation }\end{array}$ & 1 & 1.15 & 50 & $\begin{array}{c}\text { Social } \\
\text { media/internet } \\
\text { based media }\end{array}$ & 2 & -0.03 & 56 & $\begin{array}{l}\text { Multicultural } \\
\text { competency }\end{array}$ & 1 & 0.64 \\
\hline \multirow[t]{4}{*}{44} & $\begin{array}{l}\text { Computer } \\
\text { skills/ } \\
\text { database } \\
\text { managem }\end{array}$ & 2 & 0.49 & & & & & 57 & $\begin{array}{c}\text { Ordinance } \\
\text { enforcement }\end{array}$ & 1 & 1.02 \\
\hline & & & & & & & & 58 & Grant writing & 3 & 0.77 \\
\hline & & & & & & & & 59 & $\begin{array}{l}\text { Professional } \\
\text { ethics }\end{array}$ & 2 & 1.29 \\
\hline & & & & & & & & 60 & $\begin{array}{l}\text { Permitting } \\
\text { and } \\
\text { compliance }\end{array}$ & 1 & 1.19 \\
\hline
\end{tabular}

A four year college degree was the highest level of educational attainment that the employers gave a positive value. The top three highest rated educational backgrounds for entry level urban foresters from highest to lowest was urban forestry (4.56), arboriculture (4.35), and forestry (4.21). All levels of practical or internship experience received a positive rating and this rating increased with the cumulative time of the experience. The top three 
credentials were the International Society of Arboriculture Certified Arborist (4.20), commercial applicator pesticide license (3.57), and a commercial driver's license (3.38). The only other credential to get a rating above neutral was the International Society of Arboriculture Municipal Specialist (3.09). Employers in the online questionnaire gave a university certificate a positive rating (3.55) on average.

The respondents to the online questionnaire were male by a large majority $(75.9 \%$, $\mathrm{n}=178)$ with a smaller proportion female $(24.1 \%, n=57)$. The most common level of educational attainment for the respondents was a four year college degree $(56.2 \%, n=134)$, the second most common was a graduate degree $(28.7 \%, n=67)$, third most common was a two year degree $(10.4 \%, n=25)$, fourth most common was a high school diploma $(4.4 \%, n=11)$, and least common was a doctorate degree with just one respondent reporting this $(0.40 \%)$. The most common educational backgrounds for the respondents, from highest to lowest, were: forestry with $(28.3 \%, n=67)$; urban forestry $(18.6 \%, n=44)$; horticulture $(11.0 \%, n=26)$; other degree option (13.1\%, $n=31)$; natural resource management $(7.17 \%, n=17)$; arboriculture $(5.49 \%$, $\mathrm{n}=13$ ); landscape architecture, public administration, and environmental science all had the same frequency $(3.38 \%, n=8)$; urban planning $(2.95 \%, n=7)$; recreation management $(2.11 \%$, $n=5)$; civil engineering $(0.844 \%, n=2)$ and geography $(0.422 \%, n=1)$. No one selected "Sustainability Studies" as an educational background. The average age of the respondents was 47.8 years old. The average number of people the respondent managed currently was 23.7. The average number of years of experience in urban forestry was 19.1 with 13.0 years management experience in urban forestry. 
Beyond the simple summary of the data, when the associations between or influence of certain factors and the ratings given to the skills was investigated a Chi-Square test showed many significant associations. There were 177 significant associations found within the mail questionnaire, and within the online questionnaire. A multiple regression analysis was performed to try and find the factors exerting the most influence over the ratings the respondents gave for the skills or areas of knowledge that were found to have the more than one factor associated with the skill or area of knowledge. Independently a Benjamini-Hochberg procedure (McDonald 2014) was performed to reduce the false discovery rate. The relationships that were significant after both procedures are reported in the Tables $14 \& 15$. 
Table 14: Factors that were found to have significant relationships with skills using multiple regression and Benjamini-Hochberg procedures. Responses are from the mail survey.

\begin{tabular}{|c|c|c|}
\hline Factors & Value & Prevalence \\
\hline $\begin{array}{l}\text { Municipality } \\
\text { Population }\end{array}$ & None & None \\
\hline \multirow[t]{2}{*}{$\begin{array}{l}\text { Dedicated Urban } \\
\text { Forestry Division }\end{array}$} & $\begin{array}{l}\text { Urban wildlife management, tree } \\
\text { nutrition and fertilization, four year } \\
\text { college degree, landscape architecture } \\
\text { background, Ecological Society of } \\
\text { America Certified Ecologist, American } \\
\text { Society of Landscape Architects } \\
\text { Accredited Degree }\end{array}$ & $\begin{array}{c}\text { Site plan review, tree appraisal, principles of } \\
\text { utility management, heavy equipment } \\
\text { operation, budgeting, employee supervision, } \\
\text { project management, contract } \\
\text { administration, public administration, } \\
\text { volunteer organization, ordinance } \\
\text { enforcement, grant writing, four year college } \\
\text { degree }\end{array}$ \\
\hline & $\begin{array}{l}\text { Urban forest management principles, } \\
\text { water regulations, contract } \\
\text { administration, six months or less of } \\
\text { practical experience or internship }\end{array}$ & \\
\hline $\begin{array}{l}\text { Total Number of } \\
\text { Urban Foresters }\end{array}$ & $\begin{array}{l}\text { experience, nine months or less of } \\
\text { practical experience or internship } \\
\text { experience, Society of American }\end{array}$ & Political science \\
\hline & Foresters (SAF) Accredited Forestry & \\
\hline & Degree, SAF Accredited Urban Forestry & \\
\hline & Degree & \\
\hline $\begin{array}{l}\text { Total Number of } \\
\text { Entry-level Urban } \\
\text { Foresters }\end{array}$ & $\begin{array}{c}\text { Federal urban forest resource policy, } \\
\text { business management, land use } \\
\text { planning, doctorate degree }\end{array}$ & $\begin{array}{l}\text { Four year college degree, landscape } \\
\text { architecture background, }\end{array}$ \\
\hline $\begin{array}{l}\text { Entry-level positions in } \\
\text { the next year }\end{array}$ & $\begin{array}{l}\text { Ecology, park } \\
\text { administration/management, budgeting, } \\
\text { employee supervision, written } \\
\text { communication }\end{array}$ & $\begin{array}{l}\text { Park administration/management, insect } \\
\text { and disease control, tree planting } \\
\text { techniques, tree nutrition and fertilization }\end{array}$ \\
\hline $\begin{array}{l}\text { Entry-level positions in } \\
\text { the next year that will } \\
\text { be new positions }\end{array}$ & None & None \\
\hline $\begin{array}{l}\text { Entry-level positions in } \\
\text { the next five years }\end{array}$ & Public administration background & Municipal urban forest resource policy \\
\hline $\begin{array}{l}\text { Entry-level positions in } \\
\text { the next five years } \\
\text { that will be new } \\
\text { positions }\end{array}$ & None & None \\
\hline $\begin{array}{l}\text { Anticipated starting } \\
\text { salary for entry-level } \\
\text { positions }\end{array}$ & None & None \\
\hline
\end{tabular}


Table 15: Factors that were found to have significant relationships with skills using multiple regression and Benjamini-Hochberg procedures. Responses are from the online survey.

\begin{tabular}{l} 
Factors \\
\hline Public or private \\
organization \\
Municipalities by size \\
Total Number of \\
Urban Foresters \\
Total Number of \\
Entry-level Urban \\
Foresters \\
Entry-level hires in the \\
next year \\
Entry-level hires in the \\
next year that will be \\
new positions \\
Entry-level hires in the \\
next five years
\end{tabular}

Site plan review, park administration/management, hydrology/watershed management, landscape construction, public administration, two year technical or associates degree

Employee supervision, high school
diploma management, public administration, Other choice in background

Water regulations

Project management

Grant writing

None

None

None

Municipal urban forest resource policy, tree pruning and removal techniques, tree support and lightning protection, plant materials/nursery stock quality

Municipal urban forest resource policy

None

Entry-level hires in the next five years that will be new positions

Anticipated starting salary for entry-level positions

Site plan review, resiliency planning/disaster recovery, Public relations/customer service tree climbing, budgeting, business management, training/teaching, project management, contract administration, computer skills/database management, written communication, public relations/customer service, conflict resolution, media relations, community outreach/public engagement, public administration, permitting and compliance, high school diploma, four year college degree, graduate degree, public administration degree, International Society of Arboriculture Certified Arborist, International Society of Arboriculture Municipal Specialist, Society of American Foresters Accredited Forestry Degree, Society of American Foresters Urban Forestry Degree 
The existence of a dedicated urban forestry section or division within the municipality's department organization had influence or an association with the most skills or areas of knowledge with nineteen relationships significant after both procedures were performed. The number of entry-level positions in the next year had the second most with nine skills or areas of knowledge and the total number of urban foresters at the municipality had the third most with eight.

The most factor with the most influence or significant associations, for the online questionnaire, was the anticipated starting salary for the entry-level position with twenty five skills or areas of knowledge. The factor with the second most skills or areas of knowledge was the number of entry-level hires expected in the next five years, and the factor with the third most skills or areas of knowledge was whether the respondent was employed by a private or public institution with eight skills. 


\section{Chapter 4: Discussion}

The proper management of the urban forest resource is important in order to enhance its value. This large and increasing value necessitates skilled professionals that can maintain and sustain this public resource. This is why identifying what skills are needed to perform this task is so crucial. It is in this way that the most benefit can be reaped from the urban forest resource and urban foresters can keep pace with the ever-changing reality of the profession of urban forestry.

Most of the skill ratings from respondents in the surveys were positive and did not stray too far from previous research in associated fields. The technical skills in arboriculture and traditional forestry were highly valued by employers and, according to the employers surveyed, entry-level urban foresters continue to be proficient in them. The highest ranking skills within the arboriculture category were tree identification, species selection, pest control and tree removal in both the mailed and online survey (Table 3 and Table 9). Important skills and knowledge identified by respondents in the urban forestry category included tree inventory techniques, geospatial technology, and urban forest management principles and these skills were also found to be sufficient in entry level urban foresters (Table 5 and Table 11). It is encouraging that these core technical skills have been able to move with the profession and entry-level urban foresters continue to have a strong command over skills seen as critical to the performance of their duties. The high percentage of tree care companies responding to the online questionnaire might also explain the higher value rating for these more technical skills. While the survey asked specifically about urban forestry positions, the distinction between 
urban forestry and arboriculture is not always fully realized, especially by those that primarily operate as arborists. A tree care company which business is predominantly arboriculturerelated and whose employees presumably would have some arboricultural experience would understandably see arboriculture skills as being more valuable than say an urban forester working at a non-profit concerned more with community outreach and education.

This research showed some objectively positive movement in the field of urban forestry. The lack of some skills that has been identified in natural resource managers, generally, and urban foresters, specifically, was not present in the information yielded here. Crucial communication skills like oral and written communication were reported by employers as being sufficient in both the mailed and online questionnaire (Table 5 and Table 11). Entry-level urban foresters' abilities in social media and internet based media and computer skills were also seen as satisfactory. Even entry-level urban foresters' command over more sophisticated means of communication, like public relations/customer service, received positive ratings by employers. Many studies have shown that individuals at the beginning of their careers often lack these highly valuable skills of communication, which would make the satisfaction reported by employers in this research a change from what previous studies have found (Brown \& Lassoie 1998, Bullard et al. 2014, McPherson 1984, Sample et al. 1999, Sample et al. 2015, Thompson 2003). The change reported from employers is especially valuable when considering how often communication skills are shown to be highly valued by employers. However, this seemingly good news is not without qualification. There were other areas of communication did not receive satisfactory ratings. Media relations, multicultural competency, and community outreach/public engagement did not pass the standards of the employers surveyed. Similarly 
troubling, skills pertaining to working in a group and leadership, while valuable by the employers was not seen as common in entry-level urban foresters. These skills included project management, training/teaching, and conflict resolution. It is remarkable that the long standing complaint of employers in associated fields (Brown \& Lassoie 1998, Bullard et al. 2014, McPherson 1984, Mendell 2012, Sample et al. 1999, Sample et al. 2015, Thompson 2003, VanDerZanden 2009) regarding the lack of ability to simply communicate orally and in written form was absent from the responses in this study. Yet other deficiencies arose which suggests what employers think of entry-level urban forester's ability to communicate seems more nuanced. These results show that skills in group work and leadership are very important and lacking in current entry-level urban foresters. This coupled the high valuation of practical experience would suggest that students would benefit from more exposure to real world situations in their education and perhaps internships as well.

There were instances where the perceptions of the employers surveyed showed deficiencies in important current issues. Entry-level urban foresters were seen as deficient in the area of resiliency planning/disaster recovery and climate science (Table 6 and Table 12). Interestingly, the value that the employers surveyed gave to these skills was nearly neutral and negative respectively. Community involvement, volunteer organization and multicultural competency were seen as valuable, but received negative prevalence scores by the employers. Perhaps more attention could be paid to these topics to ensure that urban foresters entering the field are staying abreast to current trends and learning skills that will be needed in the future. This could point to the need of a professional organization specific to urban foresters 
that could not only disseminate information to its membership, but also facilitate meetings among professionals to discuss what skills, new and old, are important to the field.

While natural resource management, environmental science and urban planning background all received ratings above three (neutral) (Appendix IX), urban forestry, forestry and arboriculture were the highest valued backgrounds for applicants. The fact that urban forestry was the highest rated educational background validates the need for a specially trained professional to fill these urban forestry positions. One important result shown is that employers value practical, or internship, experience very highly and the more of it the better. An interesting contrast from the "softer" skills of communication and public outreach, these employers still valued the credentials showing proficiency in technical skills. This is evident in the top three certifications or licenses being certified arborist from the International Society of Forestry, commercial applicator license and commercial driver's license. The technical skills from urban forestry's arboricultural roots are still present and relevant in the profession of urban forestry.

The low staffing was not totally surprising considering previous research (O'Herrin 2013). This fact combined with about a third of cities reporting no urban forestry division or section may suggest a low level of spending on urban forestry as has been previously found (O'Herrin 2013) or perhaps a lack of education among the public to the value of their urban forest resources. More research could be performed to examine why the staffing levels are so low. Especially since the staffing levels in the online survey could be seen as inflated by the presence of private for-profit employers, specifically tree care companies, that typically hire numerous arborists and tree care workers who are not urban foresters. The majority of 
respondents in both the mail $(n=69,76 \%)$ and online $(n=146,55 \%)$ surveys reported that they anticipated not hiring any entry-level urban foresters in the next year and in both surveys, of the hires that were anticipated, the majority of those would be to fill vacancies not newly created positions.

Hiring rates were very low among most of the respondents except for a few large employers. In the mail survey it was only a small percentage $(7 \%)$ of respondents that anticipated hiring two or more entry-level urban foresters. If the number of anticipated new hires was counted in a simple tally with no exclusion of outliers, the respondents to the mail questionnaire reported an anticipated thirty nine hires of entry-level urban foresters in the next year with only nine being hires to newly created positions. This is for the ninety one municipalities where the respondents are employed. These same respondents reported 143 anticipated hires in the next five years with just forty nine being to newly created positions. This means that only about a third of those hires will be for newly created positions versus just filling in as needed do to turnover. This adds up to only about one and one half hires for the next five years per respondent, however less than half of the twenty five most populous municipalities responded to the mail questionnaire. Perhaps hiring levels would be higher if all of the most populous municipalities of the survey population had participated. The 310 respondents of the online questionnaire reported an anticipated 676 hires in the next year and 355 of them for newly created positions. These respondents reported 2,122 hires in the next five years with 1045 of these hires for newly created positions. This means that about half of the entry-level urban forester hires would be for newly created positions. Which would suggest that institutions at which the respondents worked in the online questionnaire are experiencing 
a higher level of growth. Additionally, the average number of hires per respondent was much higher in the online questionnaire; approximately four times higher than that of the mail respondents. The greater diversity of the online respondents in term of what area of the profession they work could explain this.

Despite the need to care for the environmental resources in urban areas, especially as urban populations increase, the majority of institutions employing urban foresters don't appear to be increasing in size. This could be a sign of a lack of entry-level positions in particular. These institutions might be interested in hiring experienced urban foresters, which again would show the need for a dedicated professional organization that could establish a clear career path for young professionals entering the field. The case for a professional organization is also evident in the fact that the most valued credential is one created for arborists by an organization for arborists. The SAF Urban Forestry Accredited Degree is relatively young compared to some of the other credentials and this might explain the high value ratings for other urban forestry specific education and skills, but a lower rating for this credential.

The lack of definition of the profession of urban forestry and significant overlap of skills in arboriculture show a need for urban foresters to take this issue of identity seriously. As seen in other plant-based fields that require a specialized knowledge like horticulture and botany, urban forestry runs the risk of losing its relevance and simply being incorporated into some other profession. Within the mail questionnaire, the existence of a dedicated urban forestry section and the total size of the urban forestry program, specifically how many urban foresters were employed by the municipality, had the most influence and associations with the ratings given to skills. 
The ratings given to the skills in both the mail and online questionnaire were remarkably similar. Not many of the skills seen as valuable were rated not valuable from one questionnaire to the other. The order of the rankings turned out to be different, but the ten most valuable skills reported were the same in both questionnaires. Of this top ten list of the most valuable skills, there were many arboricultural skills. Strangely, some of the skills related to current environmental issues such as: water regulations, watershed management, and climate science; were given negative value ratings in both questionnaires. The higher diversity of respondents to the online questionnaire in terms of in what field of the profession they work, particularly so many tree care companies, suggested there would be an effect on which skills were the most valued. However, one has to look to other means of summary to find the nuanced effects. Arboricultural skills made it into both questionnaires ten most important skills, but there were more arboricultural skills from the mail questionnaire that fell into the lowest valued as well. Tree climbing was one of these skills that ended up among the ten lowest valued by the mail questionnaire respondents.

Several technical skills, most of which were in the arboricultural group, were among the most prevalent in both questionnaires. Skills like tree identification, tree pruning/removal, tree planting, species selection and plant physiology were among those rated most prevalent. Somewhat surprisingly, oral communication also made the top ten most prevalent in both questionnaires and written communication in the mail questionnaire (Elmendorf 2005, McPherson 1984).

Many of the business management and public administration skills were found to be lacking in entry-level applicants while still being rated as valuable. Though certain public 
administration skills were rated much more valuable in the mail questionnaire than in the online questionnaire. Skills like public administration, ordinance enforcement and grant writing were more highly valued in the mail questionnaire, which would make sense since it was a survey exclusively of public employees. Grant writing was actually one of the very few instances there was a difference in the value given to the various skills. The mail questionnaire gave the skill of grant writing a positive value rating and the online questionnaire giving it a negative value rating. A small surprise was that the exclusively publicly employed respondents of the mail questionnaire also rated most business management skill more valuable than did the respondents to the online questionnaire which included a large portion of private companies.

Most of the skills rating between the two questionnaires were in agreement as to which skills were valuable or not valuable and which were prevalent and not prevalent. Despite this agreement, the online respondents were more discriminating and rated more skills as valuable and not prevalent. These skills fell into the problem, or needs improvement, quadrant (Table 13). The main source of this discrepancy was that online questionnaire found more arboriculture skills to be not prevalent (see Table 12) when compared to the mail questionnaire results. Perhaps this is an instance were the diversity of the respondents and a larger tree care company presence had an effect.

The challenge of defining a population for the mail survey will continue to exist until a more formal professional network for urban forestry professionals is created. The two hundred most populous U.S. municipalities were chosen to have a clearly define survey population, which was necessary for the research, however this approach lead to a bias towards the more 
heavily populated states. Texas and California received many questionnaires at the state level, twenty three and forty five respectively, (see Table 2) while other states did not receive any due to the smaller size of their municipalities. Future research could focus on one specific climatic region or state to avoid this bias. A smaller geographic focus could yield further important, and more balanced, information. A narrower survey could also eliminate the biases inherent in a convenience, or snowball, survey that befell the online survey as well.

Another challenge with establishing a survey population was the nebulous definition of what is an urban forester. Often conflated with positions in the arboricultural profession and overlapping with other professions within the urban arena, it can often be difficult to effectively communicate what exactly is meant when one uses the term urban forester. Consideration of this fact will continue to be necessary in future research. Similarly, this lack of organization or clear definition within the profession extends to the identity of urban forestry programs within municipalities. While the respondents in the mail questionnaire were asked where their municipality's urban forestry professionals were housed the overwhelming majority chose parks and recreation department for their answer. Even though they were given the choice of an urban forestry department and the majority reported having some urban forestry specific entity within which they worked. This was seen in the coding of the open-ended question at the beginning of the mail questionnaire where any use of the words "tree," "forest," or "forestry" was seen as a designation of a section or division dedicated to urban forestry activities. This complexity within a municipality's organization will be an issue of which future researchers should remain cognizant. 
This research is an important addition to the ongoing challenge of defining urban forestry. The case for the profession of urban forestry is strengthened by a more definite form. This information shows what is valued and what is needed in urban forestry professionals.

Additionally, knowing what an urban forester is makes the job of arguing why it is important to have an urban forester possible. It is by these two means that the station of the profession of urban forestry can be elevated. 


\section{Literature Cited}

Barrett, J. P. \& Baumann, S. E. (1994). Community Forests - Missing Links. Northern Journal of Applied Forestry, 11(1), 27-28.

Briggeman, B. C. \& Norwood, F. B. (2011). Employer Assessment of the College Graduate: What Advisors Need To Know. Journal of Natural Resources \& Life Sciences Education, 40, 1928.

Barkely, A. P., Stock, W. A., Sylvius, C. K. (1999). Agricultural Graduate Earning: The Impacts of College, Career, and Gender. American Journal of Agricultural Economics, 81, 785-800.

Beidler, K., Iles, J., Nusser, S. \& VanDerZanden, A. (2006). Assessing the Preparedness of Postsecondary Graduates Entering the Landscape Contracting Industry. HortTechnology, 16(2), 312-317.

Brown, T. \& Lassoie, J. (1998). Entry-Level Competency and Skill Requirements of Foresters: What Do Employers Want? Journal of Forestry, 8-14.

Bullard, S. H., Williams, P. S., Coble, T., Coble, D. W., Darville, R., \& Rogers, L. (2014). Producing "Society-Ready" Foresters: A Research-Based Process to Revise the Bachelor of Science in Forestry Curriculum at Stephen F. Austin State University. Journal of Forestry, 112(4), 354-360.

Clark, J. R., Matheny, N. P., Cross G., Wake V. (1997) A Model of Urban Forest Sustainability. Journal of Arboriculture, 23(1), 17-30.

Deneke, F. (1978). Urban Forestry Education. Journal of Arboriculture, 4(7), 154-157.

Dillman, D. A., Smyth, J. D., \& Christian, L. M. (2009). Internet, Mail, and Mixed-Mode Surveys. The Tailored Design Method. 3rd Edition. Hoboken, NJ: John Wiley \& Sons.

Dwyer, J. F. \& Childs, G. M. (2004). Movement of people across the landscape: a blurring of distinctions between areas, interests, and issues affecting natural resource management. Landscape and Urban Planning, 69, 153-164.

Dwyer, J., McPherson, E. Schroeder, H. \& Rowntree, R. (1992). Assessing The Benefits And Costs Of The Urban Forest. Journal of Arboriculture, 18(5), 227-234.

Dwyer, J., Nowak, D., \& Noble, M. (2003). Sustaining Urban Forests. Journal of Arboriculture, 29(1), 49-55. 
Elmendorf, W. F., Cotrone, V. J., Mullen, J. T. (2003). Trends in Urban Forestry Practices, Programs, and Sustainability: Contrasting Pennsylvania, U.S., Study. Journal of Arboriculture, 29(4), 237-248.

Elmendorf, W. F., \& Luloff, A. E. (2001). Using Qualitative Data Collection Methods When Planning For Community Forests. Journal of Arboriculture, 27(3), 139-151.

Fegel, T. (2014). Comparing the Educational Preferences and Management Roles of West Virginia's Male and Female Woodland Owners (Master's thesis). West Virginia University.

Gerben, J. \& Konijnendijk, C. (2007). Communication between science, policy and citizens in public participation in urban forestry-Experiences from the Neighbourwoods project. Urban Forestry \& Urban Greening, 6, 23-40.

Grant, V. (2015). Cross-boundary Conservation Attributes of Farmland and Woodland Owners in the Greenbrier River Valley Landscape of Southeastern West Virginia (Master's thesis). West Virginia University.

Harris, N., \& Stolle, F. (2016, January 5). Forests Are in the Paris Agreement! Now What? Retrieved February 26, 2016, from http://www.wri.org/blog/2016/01/forests-are-parisagreement-now-what

Hauer, R., Vogt, J., \& Fischer, B. C. (2015, October). Growing Arboriculture and Urban Forestry One Student at a Time. Arborist News, (October), 68-71.

Heyboer, G. A. (2000). Perceptions About Undergraduate Programs: A Study of Recent Graduates of the College of Agriculture and Natural Resources at Michigan State University and Their Employers. (Master's thesis). Michigan State University.

Hull, R. B. (1992). Brief Encounters With Urban Forests Produce Moods That Matter. Journal of Arboriculture, 18(6), 322-324.

Hull, R. B. (2011). Forestry's Conundrum: High Value, Low Relevance. Journal of Forestry, 109(1), 50-56.

Johnston, M. \& Shimada, L. (2004). Urban Forestry In A Multicultural Society. Journal of Arboriculture, 30(3), 185-192.

Karl, T. R, \& Koss, W. J. (1984). Regional and National Monthly, Seasonal, and Annual Temperature Weighted by Area, 1895-1983. Historical Climatology Series 4(3), National Climatic Data Center, Asheville, NC, 38 pp. 
Konijnendijk, C. C. (1997). A Short History of Urban Forestry in Europe. Journal of Arboriculture, 23(1), 31-39.

Konijnendijk, C. C. (2003). A decade of urban forestry in Europe. Forest Policy and Economics, 5, 173-186.

Konijnendijk, C., \& Randrup, T. (2004). Urban Forestry. Landscape and Planning, 471-478.

Konijnendijk, C., Ricard, R., Kenney, A., \& Randrup, T. (2006). Defining urban forestry - A comparative perspective of North America and Europe. Urban Forestry \& Urban Greening, 4, 93-103.

Lawrence, H. (1993). The Neoclassical Origins of Modern Urban Forests. Forest \& Conservation History. 37(1), 26-36.

Likert, R. 1932. A technique for the measurement of attitude. Arch. Psychol., 140.

Lilly, S.J. (2010). Arborists' Certification Study Guide. Third Edition. ISA.

Luckert, M. K. (2006). Has the Myth of the Omnipotent Forester Become the Reality of the Impotent Forester? Journal of Forestry, 104(6), 299-306.

Martilla, J. A. \& James, J. C. (1977). Importance-Performance Analysis. Journal of Marketing, 41(1), 77-79.

McDonald, J.H. 2014. Handbook of Biological Statistics, 3rd ed. Sparky House Publishing, Baltimore, Maryland.

McIntyre, N. E., Knowles-Yanez, K., Hope, D. (2000). Urban ecology as an interdisciplinary field: differences in the use of "urban" between the social and natural sciences. Urban Ecosystems, 4, 5-24.

McPherson, E. (1984). Employer Perspectives On Arboriculture Education. Journal of Arboriculture, 10(5), 137-142.

Mendell, B. C. (2012). Scientific Communication for Natural Resource Professionals. Chapter 14. American Fisheries Society.

Norwood, F. B. \& Henneberry, S. R. (2006). Show Me The Money! The Value of College Graduate Attributes As Expressed By Employers and Perceived By Students. American Journal of Agricultural Economics, 88(2), 484-498.

Nowak, D. (1994). Understanding the Structure. Journal of Forestry, 92(10), 42-46. 
Nowak, D. \& Dwyer, J. (2007). Urban and Community Forestry in the Northeast (2nd ed.). Springer.

Nowak, D., Walton, J., Dwyer, J., Kaya, L., \& Myeong, S. (2005). The Increasing Influence of Urban Environments on US Forest Management. Journal of Forestry, 377-382.

Nowak, D., Noble, M., Sisinni, S., \& Dwyer, J. (2001). People \& Trees: Assessing the US Urban Forest Resource. Journal of Forestry, 37-42.

National Urban and Community Forestry Advisory Council and the Community of Practice 20162026. Ten-Year Urban Forestry Action Plan. Retrieved from http://www.urbanforestplan.org/

O'Herrin, K. (2013). A Description of Texas Municipal Forestry Programs: How Critical Programs Elements Vary According to City Size, Expenditures, and Assistance from the State (Master's thesis). Texas State University-San Marcos.

Pritts, M. P. \& Park, T. (2013). Proposed Learning Outcomes for Four-year Horticulture Programs in the United States. HortTechnology, 23(2), 237-240.

Psacharopoulos, G. \& Patrinos, H. A. (2002). Returns to Investment in Education: A Further Update. The Policy Research Working Paper Series, 2881, 1-28.

Rupp, S. P. (2012). Practical Dissonance: Bridging the Gap Between Academia and Agencies. Wildlife Society Bulletin, 36(4), 796-801.

SAF: Certified Foresters - Becoming a Certified Forester - Eligibility Requirements http://www.safnet.org/certifiedforester/become/eligibility.cfm

Sample, V. A., Bixler, R. P., McDonough, M. H., Bullard, S. H., Snieckus, M. M. (2015). The Promise and Performance of Forestry Education in the United States: Results of a Survey of Forestry Employers, Graduates, and Educators. Journal of Forestry, 113(6), 528-537.

Sample, V., Ringgold, P., Block, N., \& Giltmier, J. (1999). Forestry Education: Adapting to the Changing Demands. Journal of Forestry, 4-10.

Schultz, T. W. (1961). Investment in Human Capital. The American Economic Review, 51(1), 117.

Schusler, T. M., Decker, D. J., Pfeffer, M. J. (2003). Social Learning for Collaborative Natural Resource Management. Society and Natural Resources: An International Journal, 16(4), 309-326. 
Sundberg, M., DeAngelis, P., Havens, K., Holsinger, K., Kennedy, K., Kramer, A., Muir, R., Olwell, P., Schiernenbeck, K., Stritch, L., \& Zorn-Arnold, B. (2011). Perceptions of Strengths and Deficiencies: Disconnects between Graduate Students and Prospective Employers. BioScience, 61(2), 133-138.

Sweetland, S. R. (1996). Human Capital Theory: Foundations of a Field of Inquiry. Review of Educational Research, 66(3), 341-359.

U.S. Census Bureau. (2010). American Fact Finder.

VanDerZanden, A. \& Reinert, M. (2009). Employer Attitudes and Perceptions of Job Preparedness of Recent lowa State University Horticulture Graduates. HortTechnology, 19(3), 647-652.

Vaux, H. (1980). Urban Forestry: Bridge to the Profession's Future. Journal of Forestry, 260-262.

Vitousek, P. M., Mooney, H. A., Lubchenco, J., Melillo, J. M. (1997). Human Domination of Earth's Ecosystems. Science 277, 494-499.

World Bank. Urban Development Overview. (2015, September 29). Retrieved February 26, 2016, from http://www.worldbank.org/en/topic/urbandevelopment/overview 


\section{Appendix I: Value, prevalence, and difference of skills rating for both questionnaires}

\begin{tabular}{|c|c|c|c|c|c|c|c|c|c|c|c|c|c|c|c|}
\hline \multirow[b]{2}{*}{$\begin{array}{l}\text { Item } \\
\text { No. }\end{array}$} & \multirow[b]{2}{*}{ Urban Forestry } & \multicolumn{3}{|c|}{$\begin{array}{c}\text { Mail } \\
\text { Responses }\end{array}$} & \multicolumn{3}{|c|}{$\begin{array}{c}\text { Online } \\
\text { Responses }\end{array}$} & \multirow[b]{2}{*}{$\begin{array}{c}\text { Item } \\
\text { No. }\end{array}$} & \multirow[b]{2}{*}{ Forestry } & \multicolumn{3}{|c|}{$\begin{array}{c}\text { Mail } \\
\text { Responses }\end{array}$} & \multicolumn{3}{|c|}{$\begin{array}{c}\text { Online } \\
\text { Responses }\end{array}$} \\
\hline & & Value & Prevalence & Difference & Value & Prevalence & Difference & & & Value & Prevalence & Difference & Value & Prevalence & Difference \\
\hline 1 & $\begin{array}{l}\text { Tree inventory } \\
\text { techniques }\end{array}$ & 3.94 & 3.55 & 0.396 & 3.95 & 3.4 & 0.55 & 11 & Soil Science & 3.73 & 3.35 & 0.385 & 3.85 & 3.1 & 0.75 \\
\hline 2 & $\begin{array}{l}\text { Urban wildlife } \\
\text { management }\end{array}$ & 2.38 & 2.57 & -0.192 & 2.5 & 2.58 & -0.08 & 12 & $\begin{array}{c}\text { Plant } \\
\text { physiology }\end{array}$ & 4.06 & 3.71 & 0.343 & 4.32 & 3.56 & 0.76 \\
\hline 3 & $\begin{array}{l}\text { GIS and } \\
\text { geospatial } \\
\text { technologies }\end{array}$ & 3.70 & 3.27 & 0.439 & 3.8 & 3.25 & 0.55 & 13 & Ecology & 3.74 & 3.23 & 0.515 & 3.79 & 3.37 & 0.42 \\
\hline 4 & $\begin{array}{l}\text { Urban forest } \\
\text { management } \\
\text { principles }\end{array}$ & 4.20 & 3.61 & 0.590 & 4.18 & 3.28 & 0.9 & 14 & $\begin{array}{c}\text { Park } \\
\text { administrat } \\
\text { ion/manag } \\
\text { ement }\end{array}$ & 3.27 & 2.73 & 0.535 & 2.99 & 2.61 & 0.38 \\
\hline 5 & $\begin{array}{l}\text { Municipal } \\
\text { urban forest } \\
\text { resource policy }\end{array}$ & 3.86 & 3.23 & 0.637 & 3.68 & 2.83 & 0.85 & 15 & $\begin{array}{c}\text { Hydrology/ } \\
\text { Watershed } \\
\text { manageme } \\
\text { nt }\end{array}$ & 3.08 & 2.65 & 0.424 & 3.06 & 2.59 & 0.47 \\
\hline 6 & $\begin{array}{l}\text { Federal urban } \\
\quad \text { forest } \\
\text { resource policy }\end{array}$ & 2.62 & 2.44 & 0.180 & 2.63 & 2.38 & 0.25 & 16 & $\begin{array}{l}\text { Climate } \\
\text { science }\end{array}$ & 2.84 & 2.60 & 0.247 & 2.88 & 2.59 & 0.29 \\
\hline 7 & $\begin{array}{c}\text { Site plan } \\
\text { review }\end{array}$ & 3.59 & 2.87 & 0.717 & 3.67 & 2.68 & 0.99 & 17 & $\begin{array}{c}\text { Weed and } \\
\text { vegetation } \\
\text { control }\end{array}$ & 3.57 & 3.20 & 0.371 & 3.78 & 2.96 & 0.82 \\
\hline 8 & $\begin{array}{l}\text { Water } \\
\text { regulations }\end{array}$ & 2.97 & 2.37 & 0.597 & 2.95 & 2.4 & 0.55 & & & & & & & & \\
\hline
\end{tabular}


Green infrastructure

planning/disa

ter recover

2.39

0.92 


\begin{tabular}{|c|c|c|c|c|c|c|c|c|c|c|c|c|c|c|c|}
\hline \multirow[b]{2}{*}{$\begin{array}{l}\text { Item } \\
\text { No. }\end{array}$} & \multirow[b]{2}{*}{ Arboriculture } & \multirow[b]{2}{*}{ Value } & \multicolumn{2}{|l|}{$\begin{array}{c}\text { Mail } \\
\text { Responses }\end{array}$} & \multicolumn{3}{|c|}{$\begin{array}{c}\text { Online } \\
\text { Responses }\end{array}$} & \multirow[b]{2}{*}{ Item No. } & \multirow[b]{2}{*}{ Managerial } & \multicolumn{3}{|c|}{$\begin{array}{c}\text { Mail } \\
\text { Responses }\end{array}$} & \multicolumn{3}{|c|}{$\begin{array}{c}\text { Online } \\
\text { Responses }\end{array}$} \\
\hline & & & Prevalence & Difference & Value & Prevalence & Difference & & & Value & Prevalence & Difference & Value & Prevalence & Difference \\
\hline 18 & $\begin{array}{c}\text { Insect and } \\
\text { disease control }\end{array}$ & 4.15 & 3.58 & 0.568 & 4.2 & 3.17 & 1.03 & 38 & Budgeting & 3.67 & 2.61 & 1.060 & 3.15 & 2.12 & 1.03 \\
\hline 19 & $\begin{array}{l}\text { Shade and } \\
\text { street tree } \\
\text { species } \\
\text { selection }\end{array}$ & 4.55 & 3.78 & 0.767 & 4.52 & 3.49 & 1.03 & 39 & $\begin{array}{c}\text { Business } \\
\text { manageme } \\
\text { nt }\end{array}$ & 3.37 & 2.52 & 0.847 & 3.04 & 2.13 & 0.91 \\
\hline 20 & $\begin{array}{l}\text { Tree planting } \\
\text { techniques }\end{array}$ & 4.65 & 3.87 & 0.786 & 4.61 & 3.67 & 0.94 & 40 & $\begin{array}{l}\text { Employee } \\
\text { supervision }\end{array}$ & 4.01 & 2.78 & 1.228 & 3.34 & 2.31 & 1.03 \\
\hline 21 & $\begin{array}{l}\text { Tree nutrition } \\
\text { and } \\
\text { fertilization }\end{array}$ & 4.00 & 3.55 & 0.446 & 3.95 & 3.22 & 0.73 & 41 & $\begin{array}{l}\text { Training/ } \\
\text { teaching }\end{array}$ & 3.98 & 3.05 & 0.930 & 3.54 & 2.47 & 1.07 \\
\hline 22 & $\begin{array}{c}\text { Tree pruning } \\
\text { and removal } \\
\text { techniques }\end{array}$ & 4.67 & 3.84 & 0.823 & 4.61 & 3.44 & 1.17 & 42 & $\begin{array}{c}\text { Project } \\
\text { manageme } \\
\text { nt }\end{array}$ & 3.87 & 2.85 & 1.020 & 3.68 & 2.47 & 1.21 \\
\hline 23 & $\begin{array}{c}\text { Root } \\
\text { management } \\
\text { and root } \\
\text { pruning }\end{array}$ & 4.05 & 3.22 & 0.829 & 4.13 & 2.85 & 1.28 & 43 & $\begin{array}{l}\text { Contract } \\
\text { administrat } \\
\text { ion }\end{array}$ & 3.71 & 2.45 & 1.255 & 3.26 & 2.11 & 1.15 \\
\hline 24 & $\begin{array}{c}\text { Water } \\
\text { management } \\
\text { and irrigation }\end{array}$ & 3.72 & 3.04 & 0.682 & 3.69 & 2.8 & 0.89 & 44 & $\begin{array}{c}\text { Computer } \\
\text { skills/ } \\
\text { database } \\
\text { manageme } \\
\text { nt }\end{array}$ & 4.36 & 3.74 & 0.626 & 4.18 & 3.69 & 0.49 \\
\hline 25 & $\begin{array}{l}\text { Landscape } \\
\text { construction }\end{array}$ & 3.28 & 2.88 & 0.401 & 3.29 & 2.6 & 0.69 & & & & & & & & \\
\hline 26 & $\begin{array}{c}\text { Landscape } \\
\text { management }\end{array}$ & 3.37 & 2.82 & 0.552 & 3.5 & 2.68 & 0.82 & & & & & & & & \\
\hline 27 & $\begin{array}{c}\text { Tree } \\
\text { identification }\end{array}$ & 4.69 & 4.12 & 0.565 & 4.77 & 3.93 & 0.84 & & & & & & & & \\
\hline
\end{tabular}




\begin{tabular}{|c|c|c|c|c|c|c|c|}
\hline 28 & $\begin{array}{c}\text { Tree support } \\
\text { and lightning } \\
\text { protection }\end{array}$ & 3.06 & 2.63 & 0.430 & 3.11 & 2.54 & 0.57 \\
\hline 29 & $\begin{array}{c}\text { Tree disorder } \\
\text { diagnostics }\end{array}$ & 4.12 & 3.31 & 0.810 & 4.21 & 2.98 & 1.23 \\
\hline 30 & $\begin{array}{c}\text { Plant } \\
\text { materials/nurs } \\
\text { ery stock } \\
\text { quality }\end{array}$ & 4.03 & 3.17 & 0.865 & 3.99 & 2.92 & 1.07 \\
\hline 31 & Tree appraisal & 3.74 & 2.74 & 0.998 & 3.39 & 2.4 & 0.99 \\
\hline 32 & $\begin{array}{l}\text { Principles of } \\
\text { utility } \\
\text { management }\end{array}$ & 3.12 & 2.46 & 0.660 & 3.21 & 2.36 & 0.85 \\
\hline 33 & $\begin{array}{c}\text { Tree } \\
\text { preservation }\end{array}$ & 4.21 & 3.22 & 0.997 & 3.98 & 2.8 & 1.18 \\
\hline 34 & $\begin{array}{l}\text { Tree } \\
\text { assessment } \\
\text { and risk } \\
\text { management }\end{array}$ & 4.48 & 3.17 & 1.314 & 4.39 & 2.86 & 1.53 \\
\hline 35 & Worker safety & 4.48 & 3.38 & 1.105 & 4.48 & 3.11 & 1.37 \\
\hline 36 & $\begin{array}{c}\text { Heavy } \\
\text { equipment } \\
\text { operation }\end{array}$ & 2.98 & 2.54 & 0.441 & 2.92 & 2.24 & 0.68 \\
\hline 37 & Tree climbing & 2.92 & 2.72 & 0.198 & 3.06 & 2.54 & 0.52 \\
\hline
\end{tabular}




\begin{tabular}{|c|c|c|c|c|c|c|c|c|c|c|c|c|c|c|c|}
\hline \multirow[b]{2}{*}{$\begin{array}{l}\text { Item } \\
\text { No. }\end{array}$} & \multirow[b]{2}{*}{ Communication } & \multicolumn{3}{|c|}{$\begin{array}{c}\text { Mail } \\
\text { Responses }\end{array}$} & \multicolumn{3}{|c|}{$\begin{array}{c}\text { Online } \\
\text { Responses }\end{array}$} & \multirow[b]{2}{*}{$\begin{array}{l}\text { Item } \\
\text { No. }\end{array}$} & \multirow[b]{2}{*}{$\begin{array}{c}\text { Public } \\
\text { Administration }\end{array}$} & \multicolumn{3}{|c|}{$\begin{array}{c}\text { Mail } \\
\text { Responses }\end{array}$} & \multicolumn{3}{|c|}{$\begin{array}{c}\text { Online } \\
\text { Responses }\end{array}$} \\
\hline & & Value & Prevalence & Difference & Value & Prevalence & Difference & & & Value & Prevalence & Difference & Value & Prevalence & Difference \\
\hline 45 & $\begin{array}{c}\text { Written } \\
\text { communication }\end{array}$ & 4.56 & 3.61 & 0.950 & 4.43 & 3.18 & 1.25 & 51 & Political science & 2.72 & 2.25 & 0.466 & 2.52 & 2.21 & 0.31 \\
\hline 46 & $\begin{array}{c}\text { Public } \\
\text { relations/custo } \\
\text { mer service }\end{array}$ & 4.68 & 3.37 & 1.313 & 4.68 & 2.99 & 1.69 & 52 & $\begin{array}{l}\text { Land use } \\
\text { planning }\end{array}$ & 3.24 & 2.58 & 0.658 & 3.19 & 2.5 & 0.69 \\
\hline 47 & $\begin{array}{c}\text { Oral } \\
\text { communication }\end{array}$ & 4.68 & 3.74 & 0.944 & 4.7 & 3.38 & 1.32 & 53 & $\begin{array}{l}\text { Community } \\
\text { outreach/ } \\
\text { public } \\
\text { engagement }\end{array}$ & 3.97 & 2.83 & 1.137 & 3.94 & 2.63 & 1.31 \\
\hline 48 & $\begin{array}{c}\text { Conflict } \\
\text { resolution }\end{array}$ & 4.41 & 2.87 & 1.540 & 4.36 & 2.61 & 1.75 & 54 & $\begin{array}{c}\text { Public } \\
\text { administration }\end{array}$ & 3.36 & 2.40 & 0.957 & 3.1 & 2.27 & 0.83 \\
\hline 49 & Media relations & 3.47 & 2.51 & 0.960 & 3.25 & 2.19 & 1.06 & 55 & $\begin{array}{l}\text { Volunteer } \\
\text { organization }\end{array}$ & 3.52 & 2.67 & 0.846 & 3.43 & 2.7 & 0.73 \\
\hline \multirow[t]{5}{*}{50} & $\begin{array}{c}\text { Social } \\
\text { media/internet } \\
\text { based media }\end{array}$ & 3.38 & 3.26 & 0.113 & 3.21 & 3.24 & -0.03 & 56 & $\begin{array}{l}\text { Multicultural } \\
\text { competency }\end{array}$ & 3.46 & 2.72 & 0.745 & 3.27 & 2.63 & 0.64 \\
\hline & & & & & & & & 57 & $\begin{array}{c}\text { Ordinance } \\
\text { enforcement }\end{array}$ & 3.90 & 2.51 & 1.386 & 3.32 & 2.3 & 1.02 \\
\hline & & & & & & & & 58 & Grant writing & 3.15 & 2.24 & 0.902 & 2.82 & 2.05 & 0.77 \\
\hline & & & & & & & & 59 & $\begin{array}{l}\text { Professional } \\
\text { ethics }\end{array}$ & 4.65 & 3.57 & 1.079 & 4.51 & 3.22 & 1.29 \\
\hline & & & & & & & & 60 & $\begin{array}{l}\text { Permitting and } \\
\text { compliance }\end{array}$ & 3.87 & 2.76 & 1.109 & 3.51 & 2.32 & 1.19 \\
\hline
\end{tabular}




\section{Appendix II: Urban forestry skills ratings comparison}
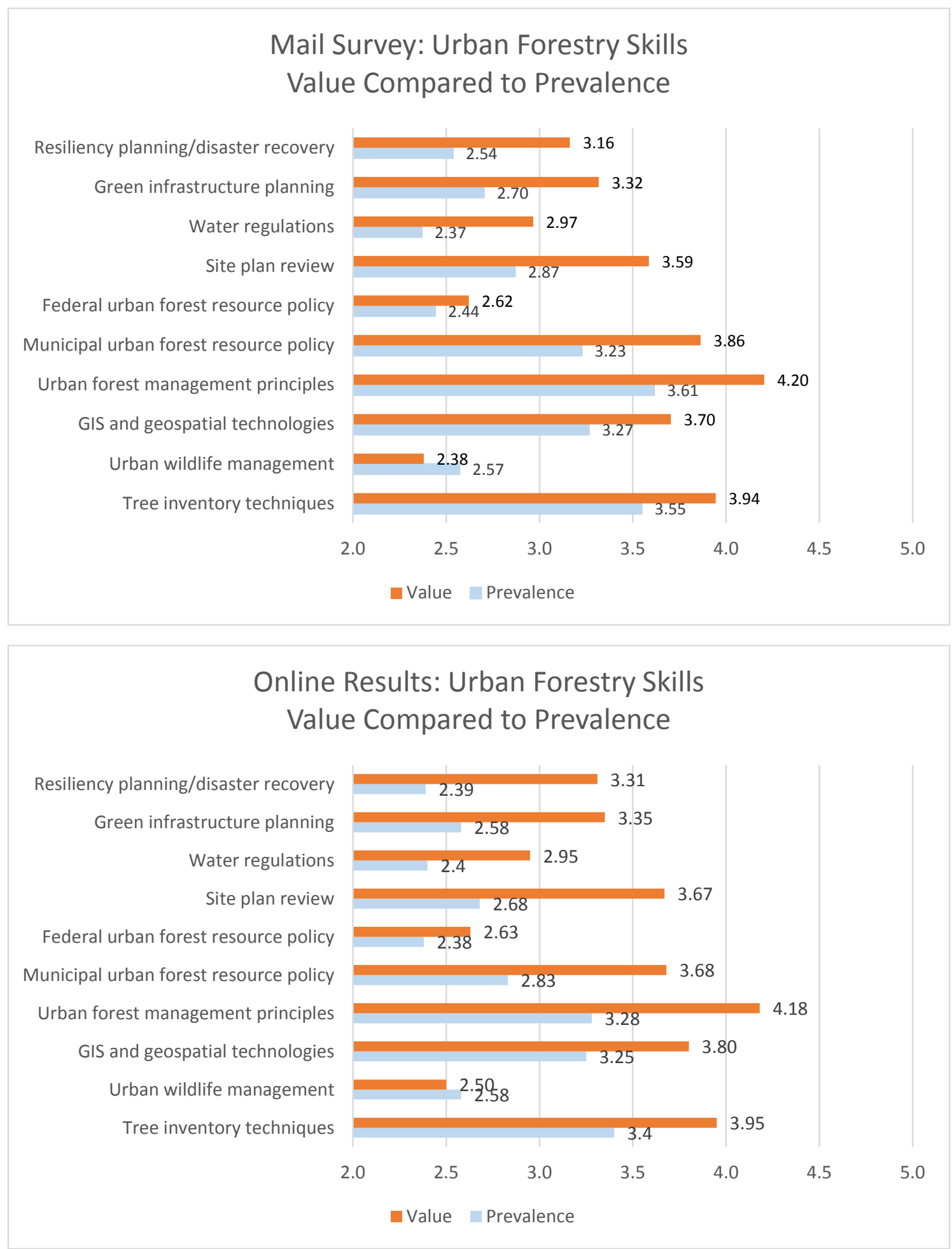


\section{Appendix III: Forestry skills ratings comparison}
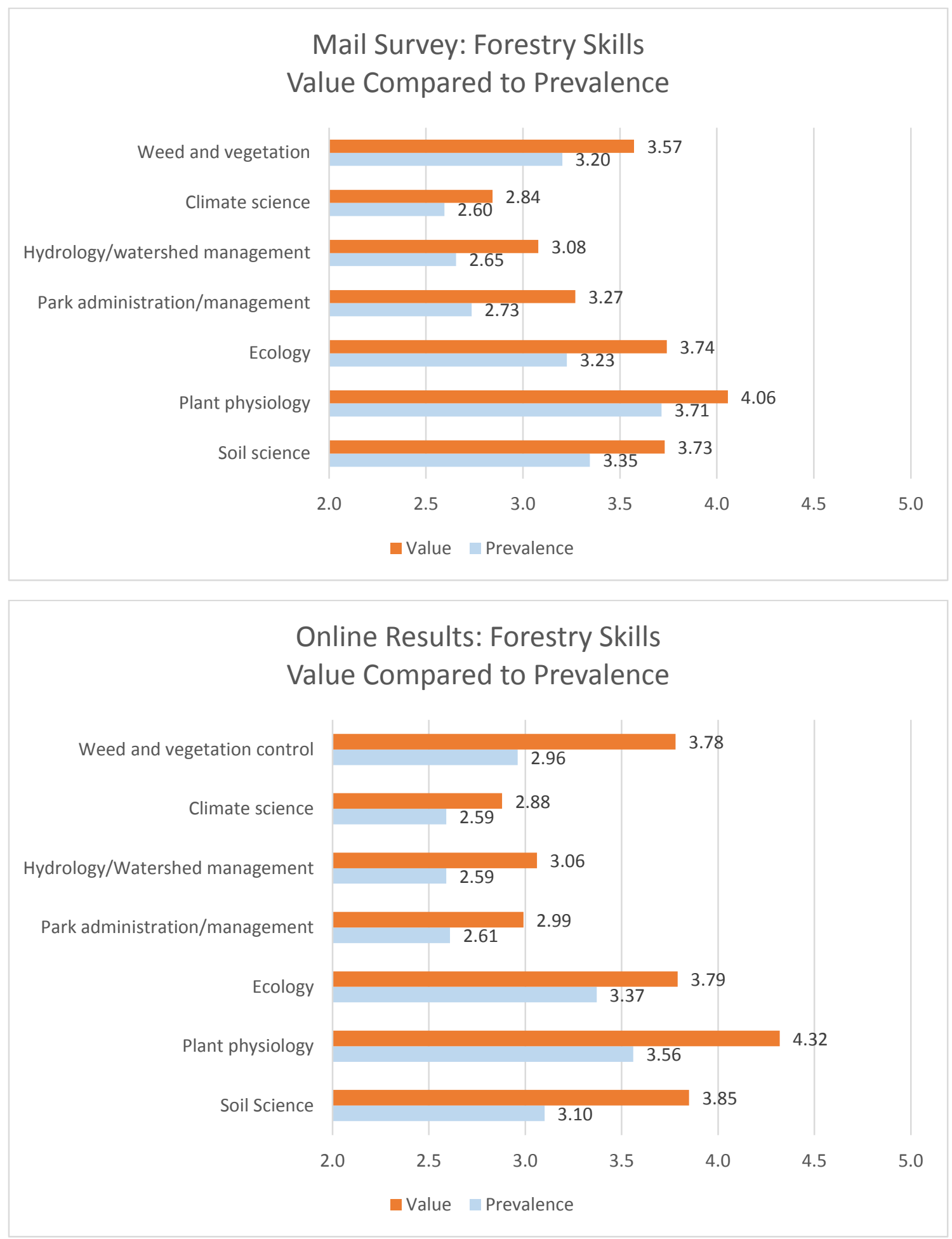


\section{Appendix IV: Arboriculture skills ratings comparison}

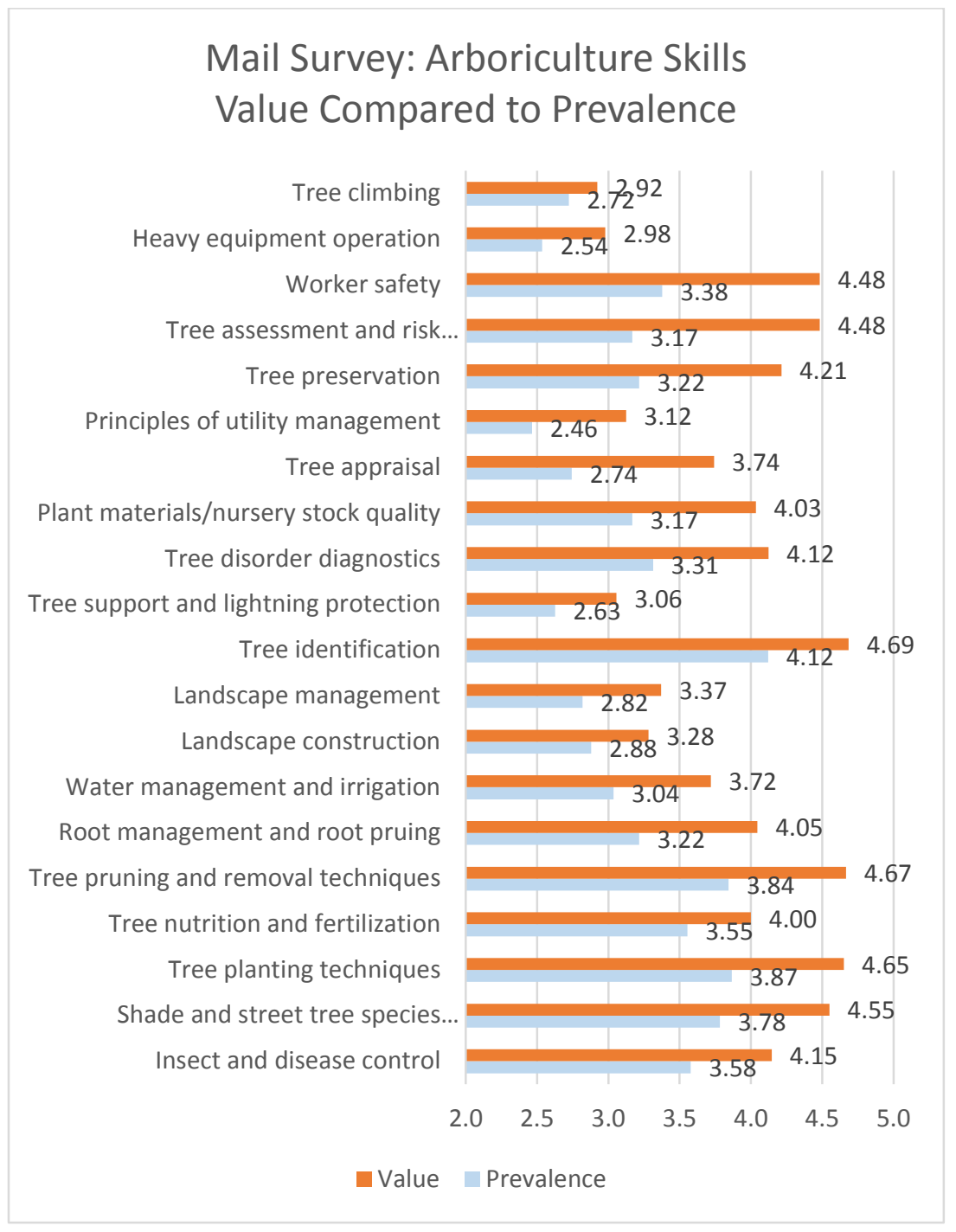

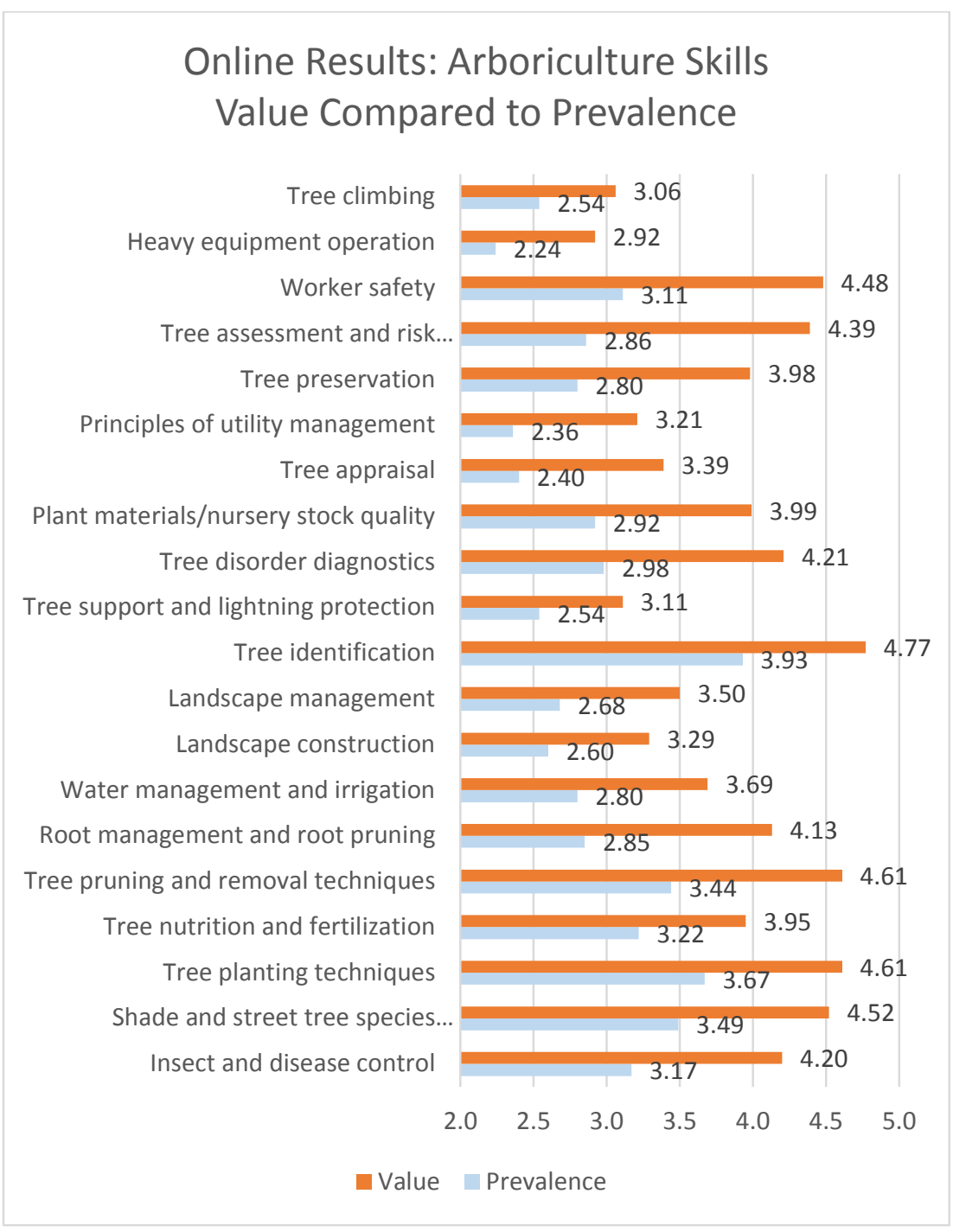




\section{Appendix V: Managerial skills ratings comparison}
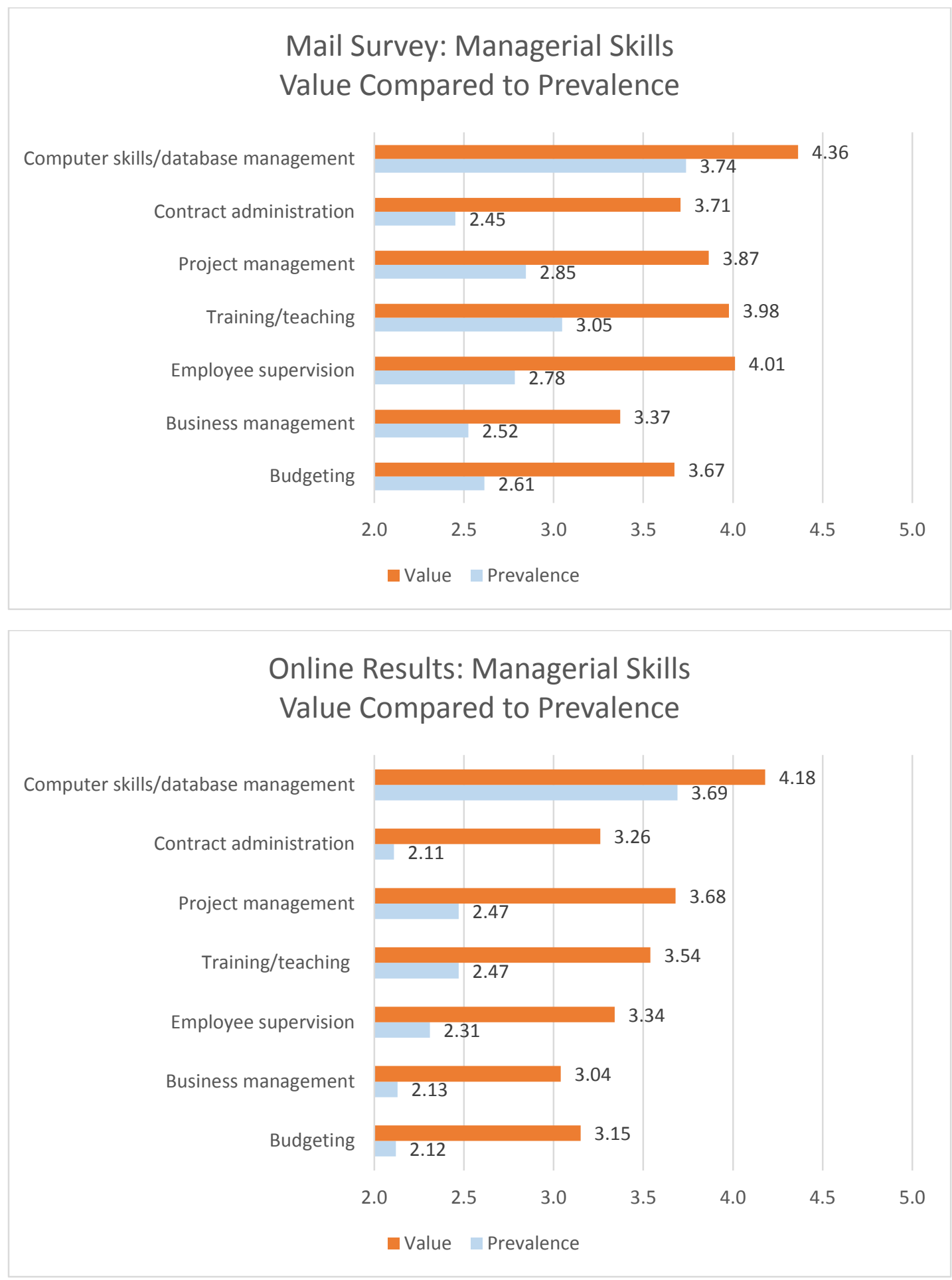


\section{Appendix VI: Communication ratings comparison}

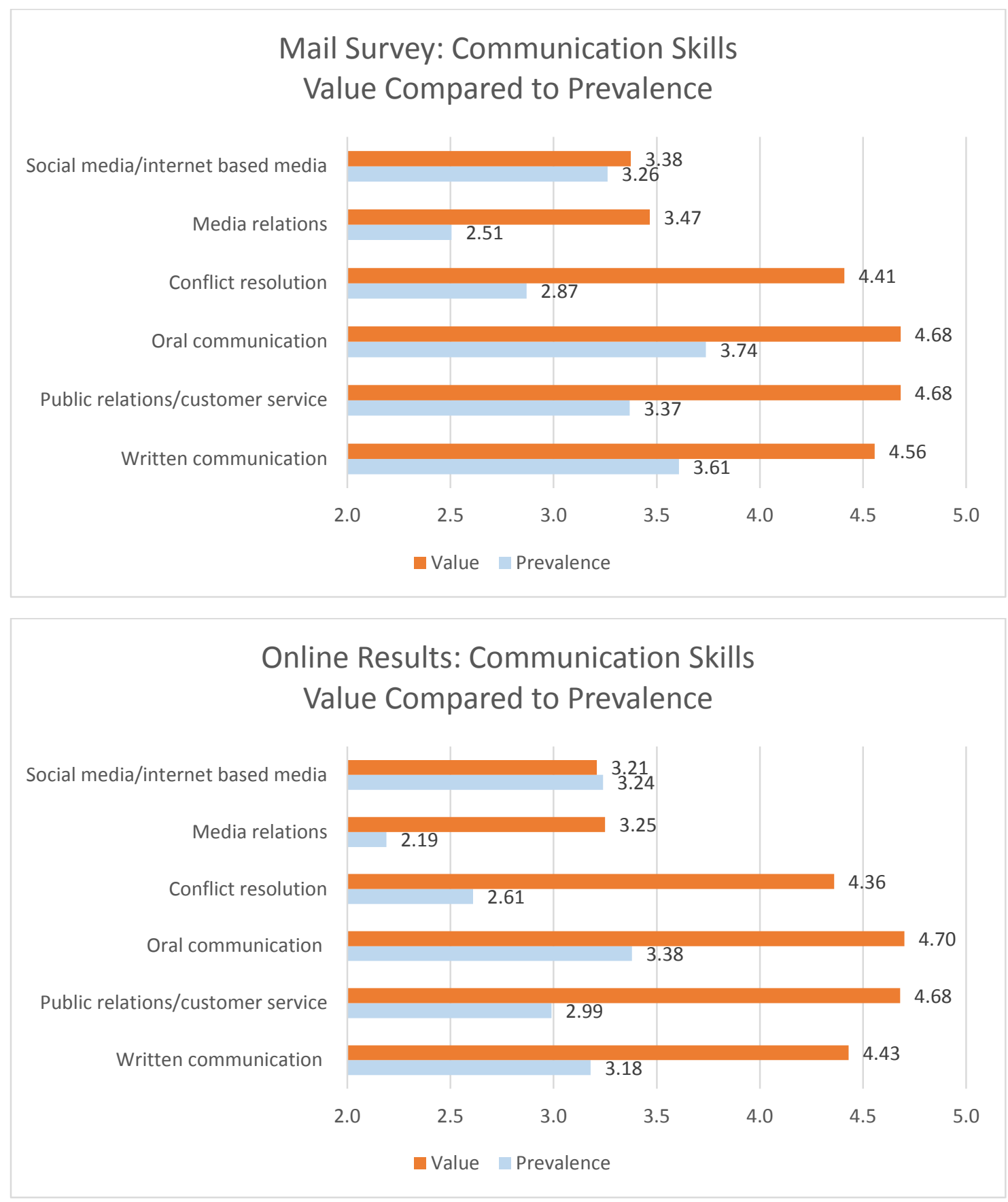




\section{Appendix VII: Public administration skills ratings comparison}
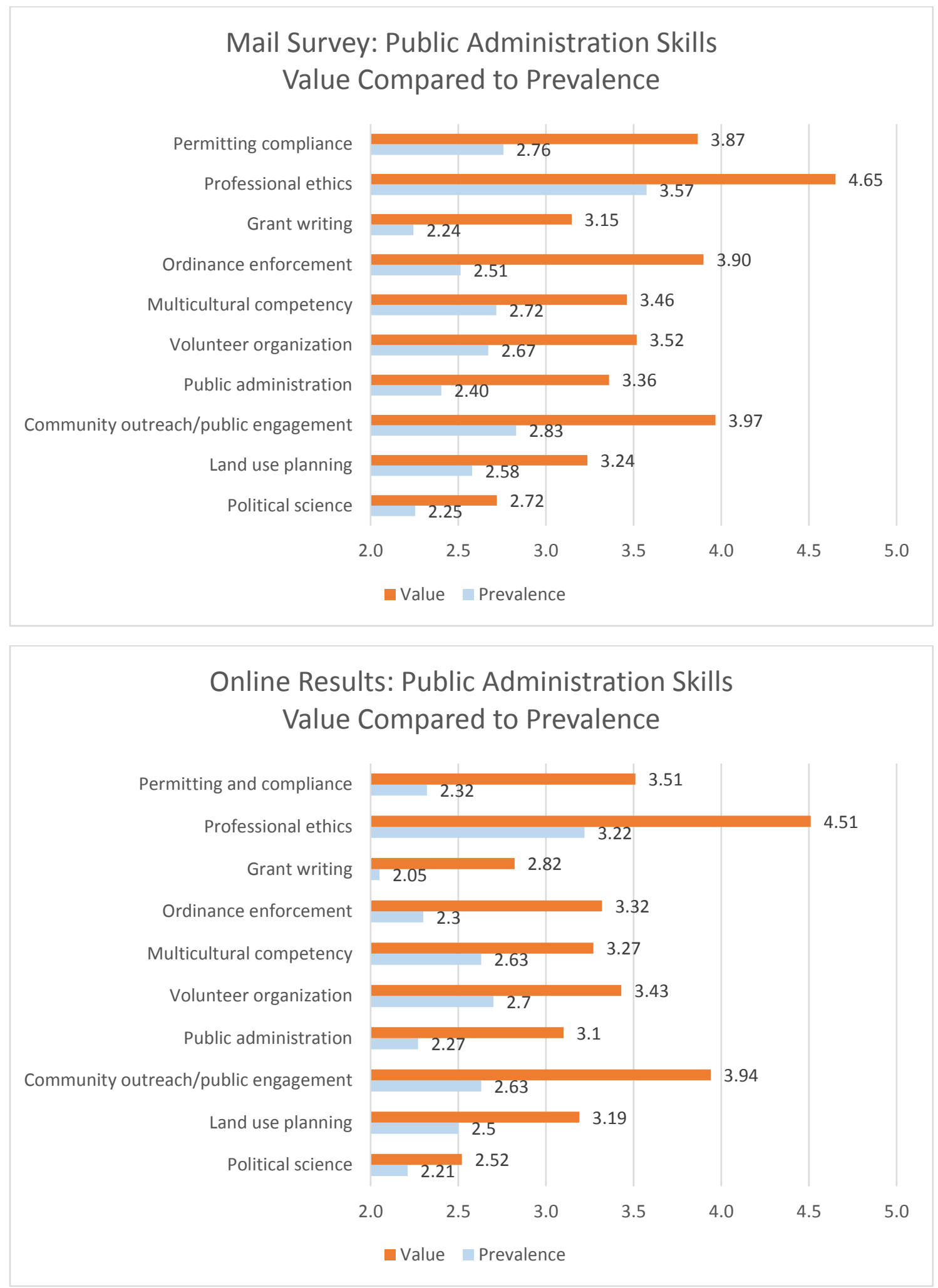


\section{Appendix VIII: Education skills ratings comparison}
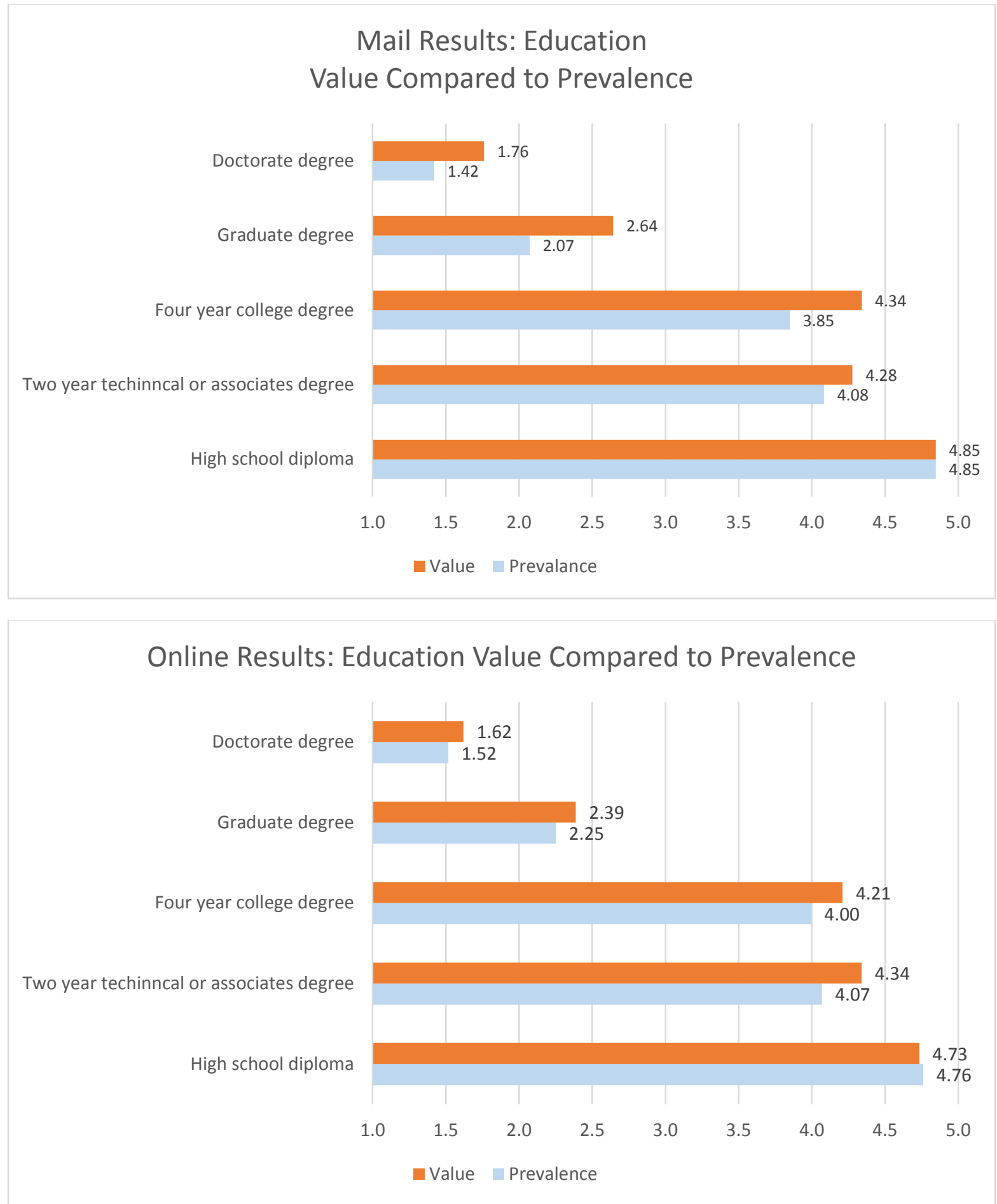


\section{Appendix IX: Educational Background Valuation}
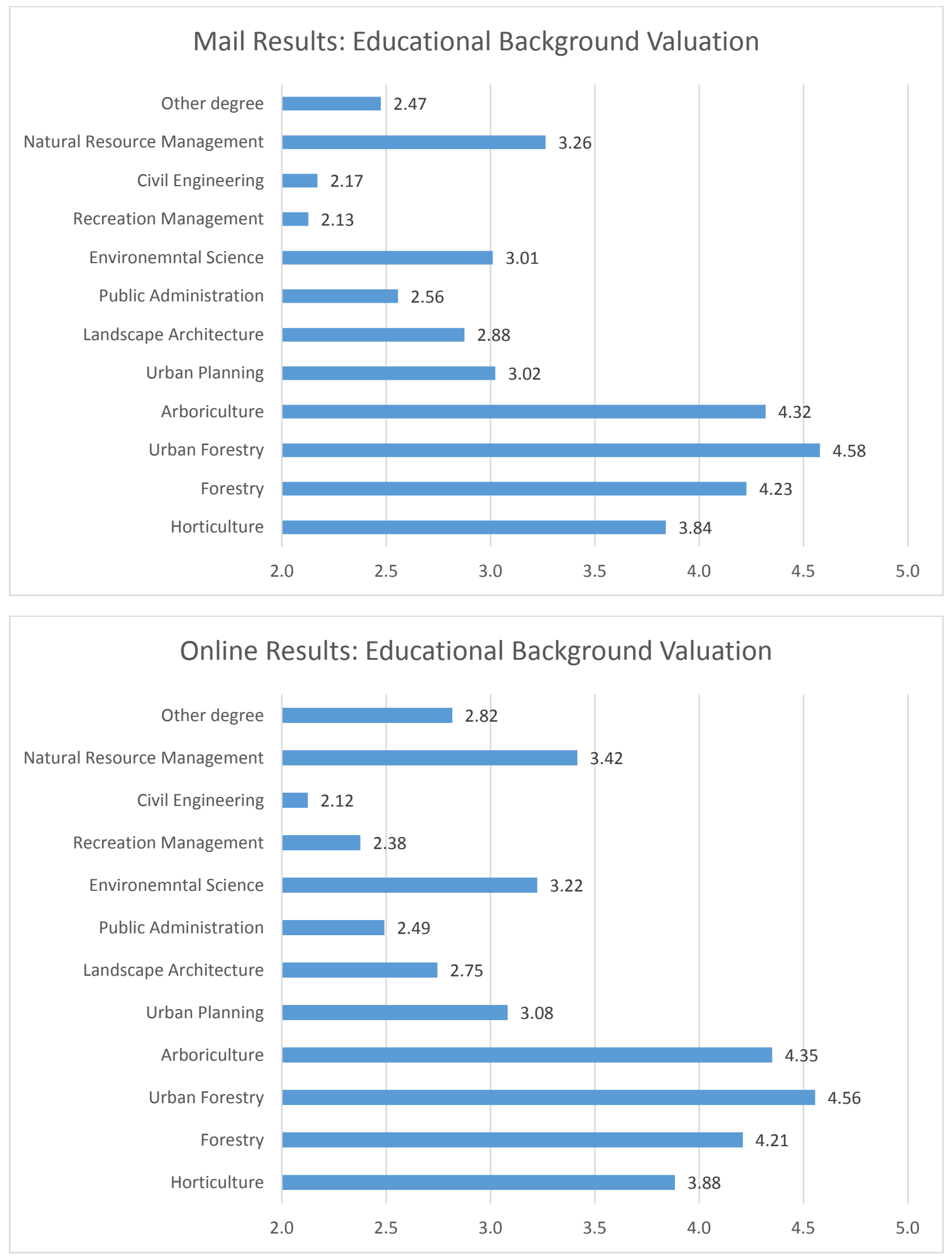


\section{Appendix X: Practical experience valuation}
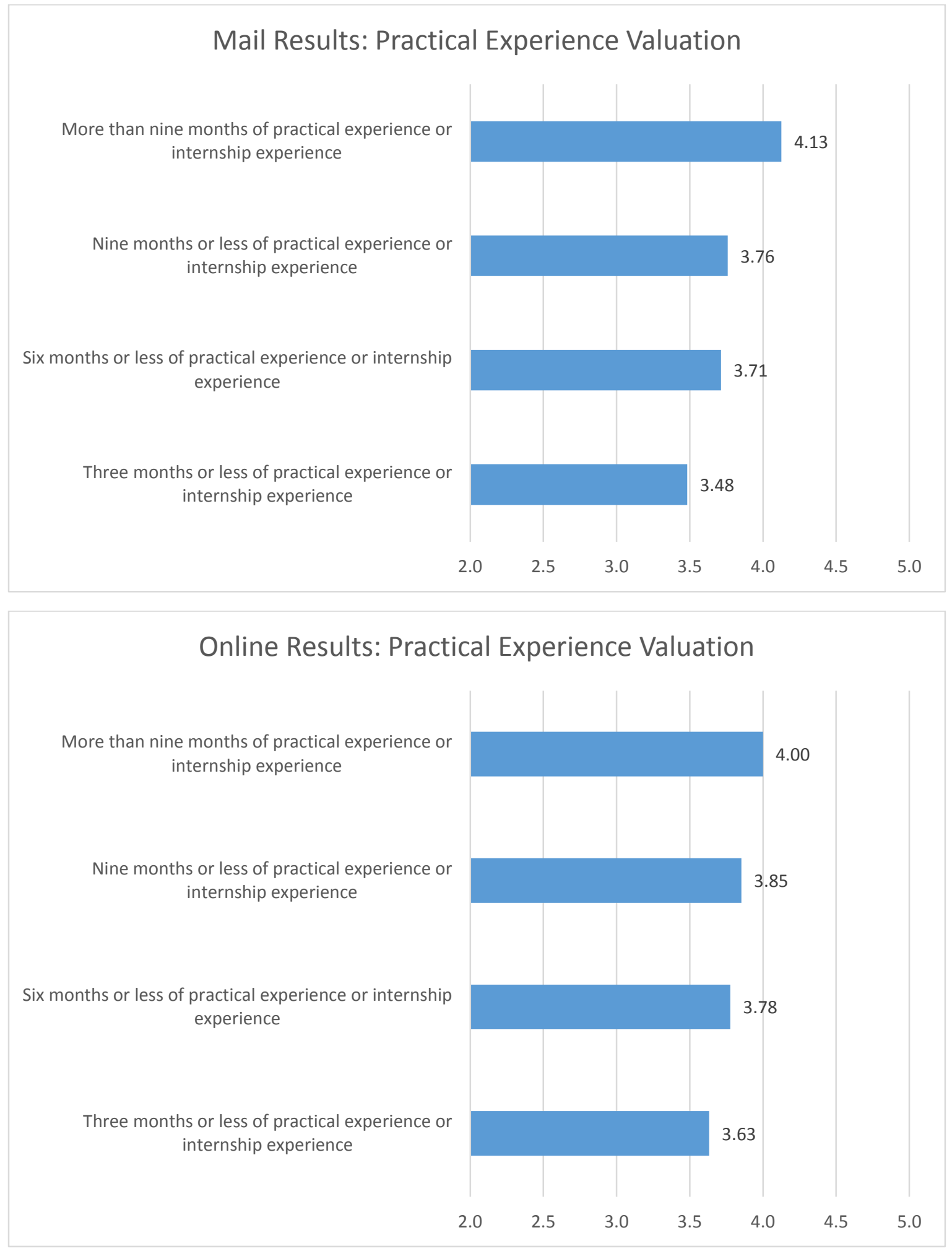


\section{Appendix XI: Credentials valuation}

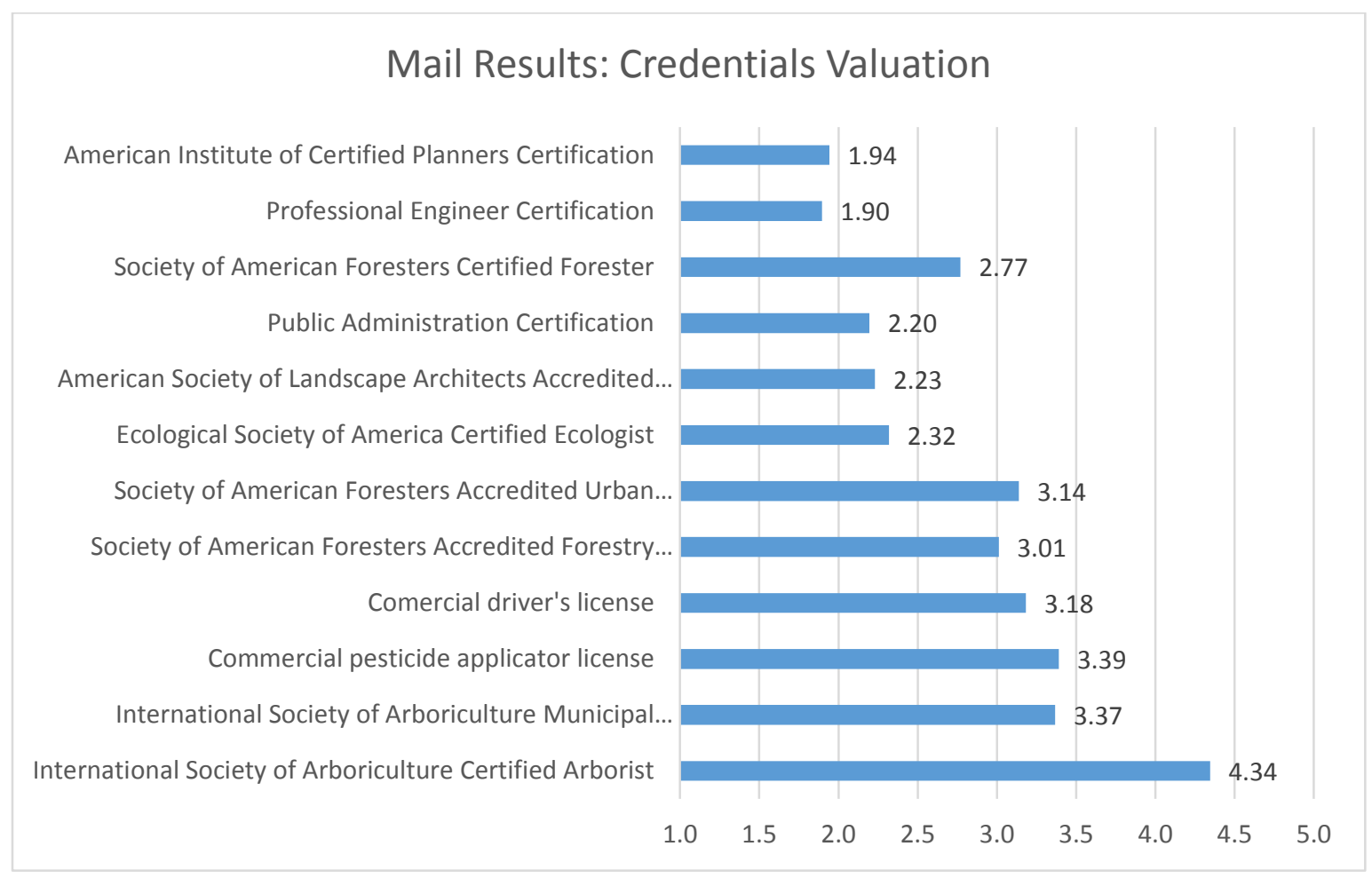

\section{Online Results: Credentials Valuation}

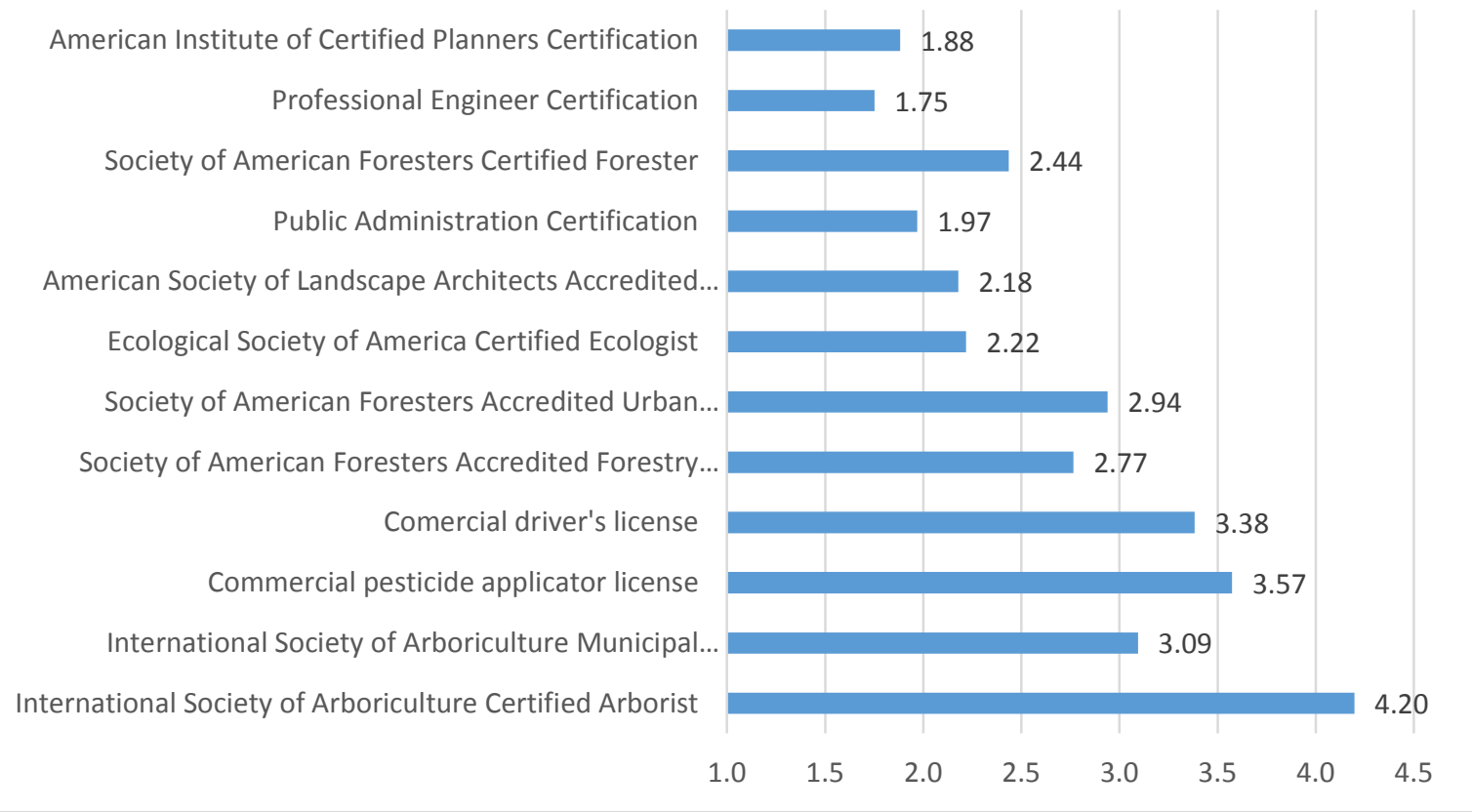




\section{Appendix XII: University certificate valuation}

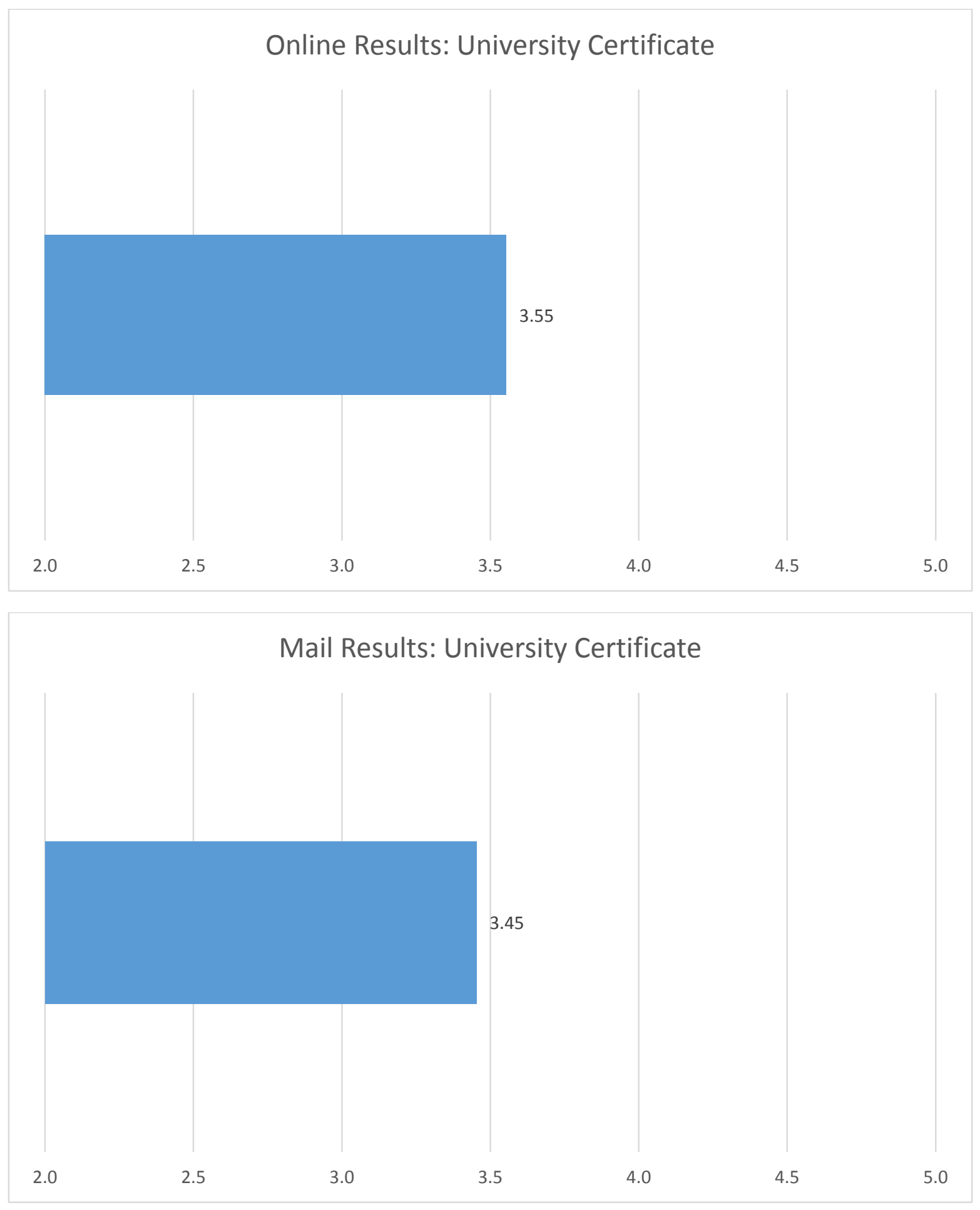




\section{Appendix XIII: Additional mail survey materials}

Figure 1: Introductory Postcard for the mail questionnaire.

Notice of Upcoming Survey

Employers in Urban Forestry

Dear Urban Forestry Employer:

A few days from now you will receive a survey designed to collect information about the perceptions of urban forestry employers. This is part of a research project that is being conducted by West Virginia University. WVU's

Institutional Review Board acknowledgement of this study is on file.

We are asking for your participation. Your insight will provide valuable information about the future of the profession of urban forestry.

Please look for this questionnaire in your mailbox. It is with your generous help that this research will be successful. Thank you in advance for your participation.

Andrew Benjamin

Graduate Research Assistant

(304) 293-6292 aebenjamin@mix.wvu.edu

WestVirginiaUniversity.

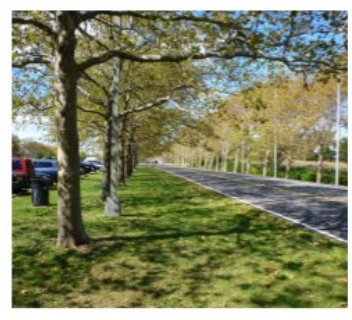

Figure 2: Reminder Postcard for the mail questionnaire.

\section{Reminder About Important Survey}

Employers in Urban Forestry

Dear Urban Forestry Employer:

Last week we mailed a survey designed to collect information about the perceptions of urban forestry employers. This is part of a research project that is being conducted by West Virginia University. WVU's Institutional Review Board acknowledgement of this study is on file.

If you have already completed and returned the survey, please accept our sincere thanks. If not, please take a few minutes to do so today. Your insight will provide valuable information about the future of the profession of urban forestry.

If you did not receive a survey or have misplaced it, please call me and I will mail another one immediately. Thank you in advance for your participation.

Andrew Benjamin

Graduate Research Assistant

(304) 293-6292 aebenjamin@mix.wvu.edu

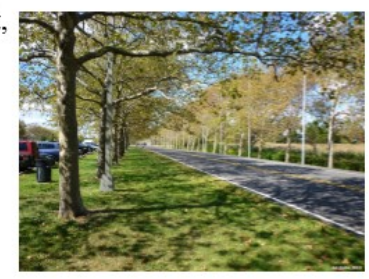

WestVirginiaUniversity. 
Figure 3: Introductory Letter for the mail questionnaire.

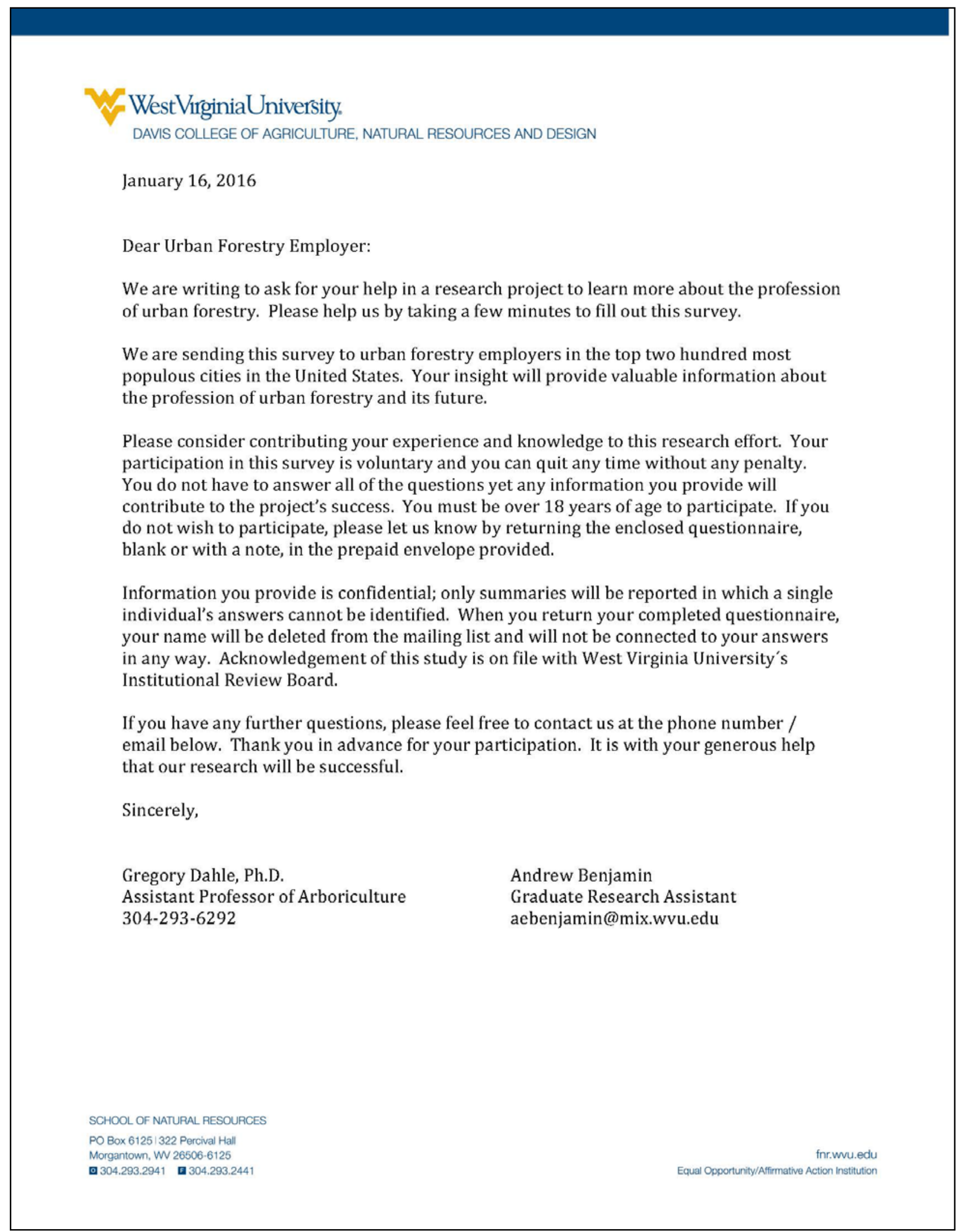




\section{Figure 4: Reminder Letter for the mail questionnaire.}

WestVriginiaUniversity.

DAVIS COLLEGE OF AGRICULTURE, NATURAL RESOURCES AND DESIGN

February 1, 2016

Dear U rban Forestry Employer:

A month ago we mailed you a questionnaire that is part of a West Virginia University research project seeking information about your knowledge and experience as an employer in the field of urban forestry. According to our records, you have not yet returned the survey.

We are writing again because your participation in this survey is important to get accurate results. Receiving your response is key to getting a representative view of the actions and attitudes of urban forestry employers throughout the country. Please consider contributing your experience and knowledge to this research effort.

Again, your participation in this survey is voluntary and you can quit any time without any penalty. You do not have to answer all of the questions, but any information you provide will contribute to the project's success. You must be over 18 years of age to participate. If you do not wish to participate, please let us know by returning the enclosed questionnaire, blank or with a note, in the prepaid envelope provided.

Information you provide is confidential; only summaries will be reported in which no individual's answers can be identified. When you return your completed questionnaire, your name will be deleted from the mailing list and will never be connected to your answers in any way. West Virginia University's Institutional Review Board acknowledgment of this study is on file.

If you have any further questions, please feel free to contact us at the phone number or email below. It is with your generous help that our research can be successful.

Sincerely,

Gregory Dahle, Ph.D. Assistant Professor of Arboriculture 304-293-6292
Andrew Benjamin

Graduate Research Assistant aebenjamin@mix.wvu.edu 


\section{Appendix XIV}

Figure 1: Mail Questionnaire

\section{Perceptions of Employers in Urban Forestry Questionnaire}

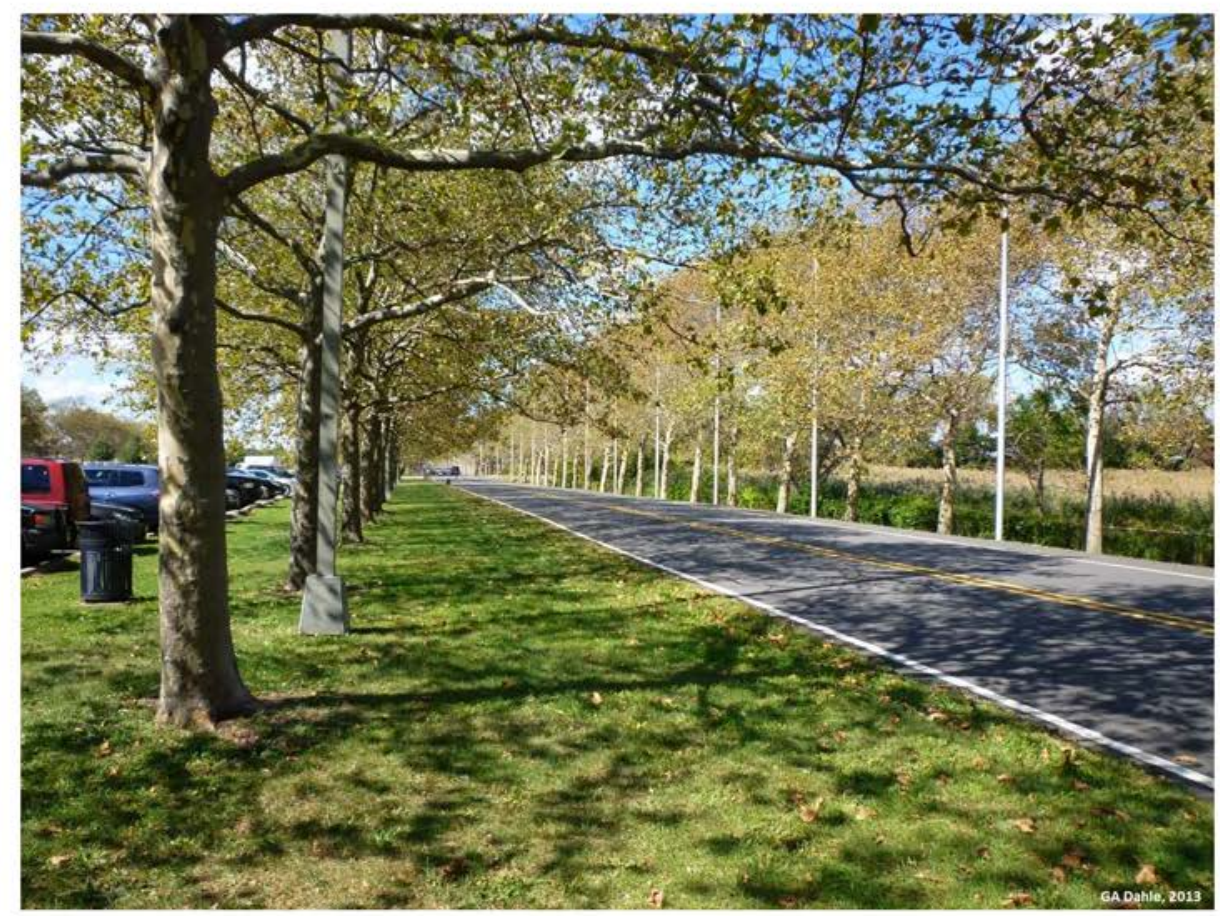

February 2016

W. WestVirginiaUniversity.

DAVIS COLLEGE OF AGRICULTURE, NATURAL RESOURCES AND DESIGN 
Page | 2 
Please return the completed questionnaire in the postage-paid envelope provided to:

\author{
Andrew Benjamin \\ West Virginia University \\ Division of Forestry \& Natural Resources \\ P.O. Box 6125
}

Morgantown, WV 26506

Please contact Andrew Benjamin (aebenjamin@mix.wvu.edu or (304) 293-6292) if you have any questions.

\begin{abstract}
About This Survey
The purpose of this research is to explore employer perceptions of the individuals applying for entry-level positions in the field of urban forestry. Your insights will provide helpful information to guide the profession of urban forestry as it progresses into the future. The urban forestry profession is undergoing a self-evaluation process. This survey is part of Urban Forestry 2020, a 3-year program helping to shape this evaluation and will be used to make strategic decisions concerning education, recruitment, and professional development opportunities in urban forestry.
\end{abstract}

Definitions: For the purpose of this research we will use the following terms as defined below.

Arboriculture is the inspection, maintenance, and protection of landscape trees to ensure their health and safety in the human environment.

Urban Forestry is the planning and management of tree resources in and around urban areas the benefit of people and the environment.

Urban Forester is an individual who may still perform arboricultural tasks but works primarily towards planning and managing urban trees at a community scale rather than a site scale

Entry-level Position would be a role within your municipality that could be filled by someone who may or may not have job specific education/training and minimal experience performing the type of work required.

Your participation is voluntary and you have the right to refrain from answering any questions. If you choose to participate, your answers will be kept confidential.

Thank you for your assistance with this important research!

\title{
Instructions:
}

- Either a pen or pencil may be used

- When answering a question with the 1 to 5 scale please circle one number

- If you need to change an answer, please make sure that your old answer is either completely erased or clearly crossed out. 
1. What is the official name of the urban forestry program within your municipality?

2. Of the following choices, which department title would be the most appropriate to describe where your urban forestry program is placed in your municipality's organizational system? (Please check only one)

Parks and Recreation Department

Public Works/Utilities Department

Environmental/Watershed Management Department

Transportation Department

Community Development Department

Planning and Engineering Department

Urban Forestry Department

Other

3. How many urban foresters are employed by your municipality? (Please provide a number)

4. How many entry-level urban foresters are employed by your municipality? (Please provide a number)

5. How many entry-level urban foresters do you predict will be hired by your municipality in the next year? (Please provide a number)

6. Of those hired how many will be new positions (i.e. not filling vacancies)? (Please provide a number)

7. How many entry-level urban foresters do you anticipate will be hired by your municipality in the next five years? (Please provide a number)

8. Of those hired how many will be new positions (i.e. not filling vacancies)? (Please provide a number)

9. What is your estimate for the starting salary of an entry-level urban forester at your establishment?

$\$ 24,999$ or less

$\$ 25,000$ to 29,999

$\$ 30,000$ to 34,999

$\$ 35,000$ to 39,999

$\$ 40,000$ to 44,999

$\$ 45,000$ to 49,999

$\$ 50,000$ to 54,999

$\$ 55,000$ to 59,999

$\$ 60,000$ to 64,999

$\$ 65,000$ to 69,999

$\$ 70,000$ or more

I don't know 
10. Please rate the importance for an entry-level urban forester to possess each of the following skills. (On a scale from 1 to 5 with 1 being not important and 5 being very important)

\begin{tabular}{|c|c|c|c|c|c|}
\hline Technical Urban Forestry & 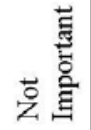 & & 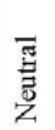 & & 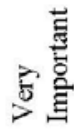 \\
\hline Tree inventory techniques & 1 & 2 & 3 & 4 & 5 \\
\hline Urban wildlife management & 1 & 2 & 3 & 4 & 5 \\
\hline GIS and geospatial technologies & 1 & 2 & 3 & 4 & 5 \\
\hline Urban forest management principles & 1 & 2 & 3 & 4 & 5 \\
\hline Municipal urban forest resource policy & 1 & 2 & 3 & 4 & 5 \\
\hline Federal urban forest resource policy & 1 & 2 & 3 & 4 & 5 \\
\hline Site plan review & 1 & 2 & 3 & 4 & 5 \\
\hline Water regulations & 1 & 2 & 3 & 4 & 5 \\
\hline Green infrastructure planning & 1 & 2 & 3 & 4 & 5 \\
\hline Resiliency planning/disaster recovery & 1 & 2 & 3 & 4 & 5 \\
\hline
\end{tabular}

\begin{tabular}{|c|c|c|c|c|c|}
\hline Technical Forestry & 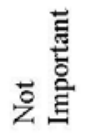 & & 焉 & & 总䓂 \\
\hline Soil Science & 1 & 2 & 3 & 4 & 5 \\
\hline Plant physiology & 1 & 2 & 3 & 4 & 5 \\
\hline Ecology & 1 & 2 & 3 & 4 & 5 \\
\hline Park administration/management & 1 & 2 & 3 & 4 & 5 \\
\hline Hydrology/Watershed management & 1 & 2 & 3 & 4 & 5 \\
\hline Climate science & 1 & 2 & 3 & 4 & 5 \\
\hline Weed and vegetation control & 1 & 2 & 3 & 4 & 5 \\
\hline
\end{tabular}




\begin{tabular}{|l|c|c|c|c|c|}
\hline \multicolumn{1}{|c|}{ Technical Arboriculture } & & & & \\
& & & & & \\
& & & & \\
& & & & \\
& & 2 & 3 & 4 & 5 \\
\hline Insect and disease control & 1 & 2 & 3 & 4 & 5 \\
\hline Shade and street tree species selection & 1 & 2 & 3 & 4 & 5 \\
\hline Tree planting techniques & 1 & 2 & 3 & 4 & 5 \\
\hline Tree nutrition and fertilization & 1 & 2 & 3 & 4 & 5 \\
\hline Tree pruning and removal techniques & 1 & 2 & 3 & 4 & 5 \\
\hline Root management and root pruning & 1 & 2 & 3 & 4 & 5 \\
\hline Water management and irrigation & 1 & 2 & 3 & 4 & 5 \\
\hline Landscape construction & 1 & 2 & 3 & 4 & 5 \\
\hline Landscape management & 1 & 2 & 3 & 4 & 5 \\
\hline Tree identification & 1 & 2 & 3 & 4 & 5 \\
\hline Tree support and lightning protection & 1 & 2 & 3 & 4 & 5 \\
\hline Tree disorder diagnostics & 1 & 2 & 3 & 4 & 5 \\
\hline Plant materials/nursery stock quality & 1 & 2 & 3 & 4 & 5 \\
\hline Tree appraisal & 1 & 2 & 3 & 4 & 5 \\
\hline Principles of utility management & 1 & 2 & 3 & 4 & 5 \\
\hline Tree preservation & 1 & 2 & 3 & 4 & 5 \\
\hline Tree assessment and risk management & 1 & 2 & 3 & 4 & 5 \\
\hline Worker safety & 1 & 2 & 3 & 4 & 5 \\
\hline Heavy equipment operation & 1 & 2 & 3 & 4 & 5 \\
\hline Tree climbing & & & & \\
\hline
\end{tabular}

\begin{tabular}{|c|c|c|c|c|c|}
\hline Managerial & 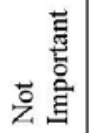 & & 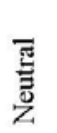 & & 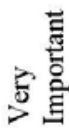 \\
\hline Budgeting & 1 & 2 & 3 & 4 & 5 \\
\hline Business management & 1 & 2 & 3 & 4 & 5 \\
\hline Employee supervision & 1 & 2 & 3 & 4 & 5 \\
\hline Training/teaching & 1 & 2 & 3 & 4 & 5 \\
\hline Project management & 1 & 2 & 3 & 4 & 5 \\
\hline Contract administration & 1 & 2 & 3 & 4 & 5 \\
\hline Computer skills/database management & 1 & 2 & 3 & 4 & 5 \\
\hline
\end{tabular}




\begin{tabular}{|c|c|c|c|c|c|}
\hline Communication & 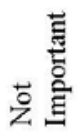 & & 丞 & & > \\
\hline Written communication & 1 & 2 & 3 & 4 & 5 \\
\hline Public relations/customer service & 1 & 2 & 3 & 4 & 5 \\
\hline Oral communication & 1 & 2 & 3 & 4 & 5 \\
\hline Conflict resolution & 1 & 2 & 3 & 4 & 5 \\
\hline Media relations & 1 & 2 & 3 & 4 & 5 \\
\hline Social media/internet based media & 1 & 2 & 3 & 4 & 5 \\
\hline
\end{tabular}

\begin{tabular}{|c|c|c|c|c|c|}
\hline Public Administration & 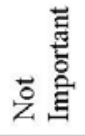 & & 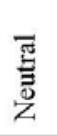 & & 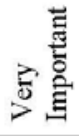 \\
\hline Political science & 1 & 2 & 3 & 4 & 5 \\
\hline Land use planning & 1 & 2 & 3 & 4 & 5 \\
\hline Community outreach/public engagement & 1 & 2 & 3 & 4 & 5 \\
\hline Public administration & 1 & 2 & 3 & 4 & 5 \\
\hline Volunteer organization & 1 & 2 & 3 & 4 & 5 \\
\hline Multicultural competency & 1 & 2 & 3 & 4 & 5 \\
\hline Ordinance enforcement & 1 & 2 & 3 & 4 & 5 \\
\hline Grant writing & 1 & 2 & 3 & 4 & 5 \\
\hline Professional ethics & 1 & 2 & 3 & 4 & 5 \\
\hline Permitting and compliance & 1 & 2 & 3 & 4 & 5 \\
\hline
\end{tabular}

Page | 7 
11. Please rate the prevalence for an entry-level urban forester to possess each of the following skills. (On a scale from 1 to 5 with 1 often lacking and 5 being often present)

\begin{tabular}{|c|c|c|c|c|c|}
\hline Technical Urban Forestry & 异总莺 & & 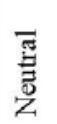 & & 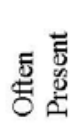 \\
\hline Tree inventory techniques & 1 & 2 & 3 & 4 & 5 \\
\hline Urban wildlife management & 1 & 2 & 3 & 4 & 5 \\
\hline GIS and geospatial technologies & 1 & 2 & 3 & 4 & 5 \\
\hline Urban forest management principles & 1 & 2 & 3 & 4 & 5 \\
\hline Municipal urban forest resource policy & 1 & 2 & 3 & 4 & 5 \\
\hline Federal urban forest resource policy & 1 & 2 & 3 & 4 & 5 \\
\hline Site plan review & 1 & 2 & 3 & 4 & 5 \\
\hline Water regulations & 1 & 2 & 3 & 4 & 5 \\
\hline Green infrastructure planning & 1 & 2 & 3 & 4 & 5 \\
\hline Resiliency planning/disaster recovery & 1 & 2 & 3 & 4 & 5 \\
\hline
\end{tabular}

\begin{tabular}{|c|c|c|c|c|c|}
\hline Technical Forestry & 홀 & & 预 & & 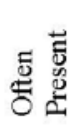 \\
\hline Soil Science & 1 & 2 & 3 & 4 & 5 \\
\hline Plant physiology & 1 & 2 & 3 & 4 & 5 \\
\hline Ecology & 1 & 2 & 3 & 4 & 5 \\
\hline Park administration/management & 1 & 2 & 3 & 4 & 5 \\
\hline Hydrology/Watershed management & 1 & 2 & 3 & 4 & 5 \\
\hline Climate science & 1 & 2 & 3 & 4 & 5 \\
\hline Weed and vegetation control & 1 & 2 & 3 & 4 & 5 \\
\hline
\end{tabular}




\begin{tabular}{|l|c|c|c|c|c|}
\hline \multicolumn{1}{|c|}{ Technical Arboriculture } & & & & \\
& & & & & \\
& & & & \\
& & & & \\
& & 2 & 3 & 4 & 5 \\
\hline Insect and disease control & 1 & 2 & 3 & 4 & 5 \\
\hline Shade and street tree species selection & 1 & 2 & 3 & 4 & 5 \\
\hline Tree planting techniques & 1 & 2 & 3 & 4 & 5 \\
\hline Tree nutrition and fertilization & 1 & 2 & 3 & 4 & 5 \\
\hline Tree pruning and removal techniques & 1 & 2 & 3 & 4 & 5 \\
\hline Root management and root pruning & 1 & 2 & 3 & 4 & 5 \\
\hline Water management and irrigation & 1 & 2 & 3 & 4 & 5 \\
\hline Landscape construction & 1 & 2 & 3 & 4 & 5 \\
\hline Landscape management & 1 & 2 & 3 & 4 & 5 \\
\hline Tree identification & 1 & 2 & 3 & 4 & 5 \\
\hline Tree support and lightning protection & 1 & 2 & 3 & 4 & 5 \\
\hline Tree disorder diagnostics & 1 & 2 & 3 & 4 & 5 \\
\hline Plant materials/nursery stock quality & 1 & 2 & 3 & 4 & 5 \\
\hline Tree appraisal & 1 & 2 & 3 & 4 & 5 \\
\hline Principles of utility management & 1 & 2 & 3 & 4 & 5 \\
\hline Tree preservation & 1 & 2 & 3 & 4 & 5 \\
\hline Tree assessment and risk management & 1 & 2 & 3 & 4 & 5 \\
\hline Worker safety & 1 & 2 & 3 & 4 & 5 \\
\hline Heavy equipment operation & 1 & 2 & 3 & 4 & 5 \\
\hline Tree climbing & & & & \\
\hline
\end{tabular}

\begin{tabular}{|c|c|c|c|c|c|}
\hline Managerial & 总兽兽 & & $\begin{array}{l}\overline{\mathbb{E}} \\
\bar{\Xi} \\
\text { 乙 }\end{array}$ & & 总 \\
\hline Budgeting & 1 & 2 & 3 & 4 & 5 \\
\hline Business management & 1 & 2 & 3 & 4 & 5 \\
\hline Employee supervision & 1 & 2 & 3 & 4 & 5 \\
\hline Training/teaching & 1 & 2 & 3 & 4 & 5 \\
\hline Project management & 1 & 2 & 3 & 4 & 5 \\
\hline Contract administration & 1 & 2 & 3 & 4 & 5 \\
\hline Computer skills/database management & 1 & 2 & 3 & 4 & 5 \\
\hline
\end{tabular}




\begin{tabular}{|c|c|c|c|c|c|}
\hline Communication & 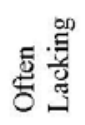 & & 焉 & & 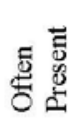 \\
\hline Written communication & 1 & 2 & 3 & 4 & 5 \\
\hline Public relations/customer service & 1 & 2 & 3 & 4 & 5 \\
\hline Oral communication & 1 & 2 & 3 & 4 & 5 \\
\hline Conflict resolution & 1 & 2 & 3 & 4 & 5 \\
\hline Media relations & 1 & 2 & 3 & 4 & 5 \\
\hline Social media/internet based media & 1 & 2 & 3 & 4 & 5 \\
\hline
\end{tabular}

\begin{tabular}{|c|c|c|c|c|c|}
\hline Public Administration & 总总莺 & & 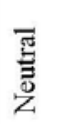 & & 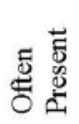 \\
\hline Political science & 1 & 2 & 3 & 4 & 5 \\
\hline Land use planning & 1 & 2 & 3 & 4 & 5 \\
\hline Community outreach/public engagement & 1 & 2 & 3 & 4 & 5 \\
\hline Public administration & 1 & 2 & 3 & 4 & 5 \\
\hline Volunteer organization & 1 & 2 & 3 & 4 & 5 \\
\hline Multicultural competency & 1 & 2 & 3 & 4 & 5 \\
\hline Ordinance enforcement & 1 & 2 & 3 & 4 & 5 \\
\hline Grant writing & 1 & 2 & 3 & 4 & 5 \\
\hline Professional ethics & 1 & 2 & 3 & 4 & 5 \\
\hline Permitting and compliance & 1 & 2 & 3 & 4 & 5 \\
\hline
\end{tabular}

12. Please rate the importance for an entry-level urban forester to have completed the following education. (On a scale from 1 to 5 with 1 being not important and 5 being very important)

\begin{tabular}{|c|c|c|c|c|c|}
\hline Education Level & 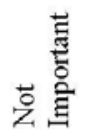 & & $\begin{array}{l}\overline{\mathbb{E}} \\
\overline{\bar{E}} \\
\text { Z }\end{array}$ & & 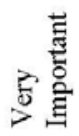 \\
\hline High school diploma & 1 & 2 & 3 & 4 & 5 \\
\hline 2 year technical or associates degree & 1 & 2 & 3 & 4 & 5 \\
\hline 4 year college degree & 1 & 2 & 3 & 4 & 5 \\
\hline Graduate degree & 1 & 2 & 3 & 4 & 5 \\
\hline Doctorate degree & 1 & 2 & 3 & 4 & 5 \\
\hline
\end{tabular}


13. Please rate the prevalence for an entry level urban forestry to have completed the following education. (On a scale from 1 to 5 with 1 being not important and 5 being very important)

\begin{tabular}{|c|c|c|c|c|c|}
\hline Education Level & 扂芯 & & 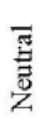 & & 志 \\
\hline High school diploma & 1 & 2 & 3 & 4 & 5 \\
\hline 2 year technical or associates degree & 1 & 2 & 3 & 4 & 5 \\
\hline 4 year college degree & 1 & 2 & 3 & 4 & 5 \\
\hline Graduate degree & 1 & 2 & 3 & 4 & 5 \\
\hline Doctorate degree & 1 & 2 & 3 & 4 & 5 \\
\hline
\end{tabular}

14. Please rate the importance for an entry-level urban forester to possess a degree in the following areas of study. (On a scale from 1 to 5 with 1 being not important and 5 being very important)

\begin{tabular}{|c|c|c|c|c|c|}
\hline Area of Study & 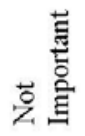 & & $\begin{array}{l}\bar{\pi} \\
\text { 吾 } \\
\text { Z }\end{array}$ & & 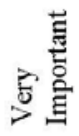 \\
\hline Horticulture & 1 & 2 & 3 & 4 & 5 \\
\hline Forestry & 1 & 2 & 3 & 4 & 5 \\
\hline Urban Forestry & 1 & 2 & 3 & 4 & 5 \\
\hline Arboriculture & 1 & 2 & 3 & 4 & 5 \\
\hline Urban Planning & 1 & 2 & 3 & 4 & 5 \\
\hline Landscape Architecture & 1 & 2 & 3 & 4 & 5 \\
\hline Public Administration & 1 & 2 & 3 & 4 & 5 \\
\hline Environmental Science & 1 & 2 & 3 & 4 & 5 \\
\hline Recreation Management & 1 & 2 & 3 & 4 & 5 \\
\hline Civil Engineering & 1 & 2 & 3 & 4 & 5 \\
\hline Natural Resource Management & 1 & 2 & 3 & 4 & 5 \\
\hline Other degree & 1 & 2 & 3 & 4 & 5 \\
\hline
\end{tabular}


15. Please rate the importance for an entry-level urban forester to possess the following practical knowledge. (On a scale from 1 to 5 with 1 being not important and 5 being very important)

\begin{tabular}{|c|c|c|c|c|c|}
\hline Practical Experience & 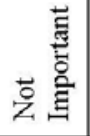 & & 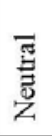 & & 点莺 \\
\hline $\begin{array}{l}3 \text { months or less of practical experience or internship } \\
\text { experience }\end{array}$ & 1 & 2 & 3 & 4 & 5 \\
\hline $\begin{array}{l}6 \text { months or less of practical experience or internship } \\
\text { experience }\end{array}$ & 1 & 2 & 3 & 4 & 5 \\
\hline $\begin{array}{l}9 \text { months or less of practical experience or internship } \\
\text { experience }\end{array}$ & 1 & 2 & 3 & 4 & 5 \\
\hline $\begin{array}{l}\text { More than } 9 \text { months of practical experience or } \\
\text { internship experience }\end{array}$ & 1 & 2 & 3 & 4 & 5 \\
\hline
\end{tabular}

\begin{tabular}{|c|c|c|c|c|c|}
\hline Credentials & 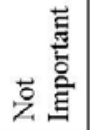 & & $\begin{array}{l}\overline{\mathbb{N}} \\
\text { 莺 }\end{array}$ & & 莺产 \\
\hline $\begin{array}{l}\text { International Society of Arboriculture (ISA) Certified } \\
\text { Arborist }\end{array}$ & 1 & 2 & 3 & 4 & 5 \\
\hline ISA Certified Arborist Municipal Specialist & 1 & 2 & 3 & 4 & 5 \\
\hline Commercial pesticide applicator license & 1 & 2 & 3 & 4 & 5 \\
\hline Commercial driver's license & 1 & 2 & 3 & 4 & 5 \\
\hline $\begin{array}{l}\text { Society of American Foresters (SAF) Accredited } \\
\text { Forestry Degree }\end{array}$ & 1 & 2 & 3 & 4 & 5 \\
\hline SAF Accredited Urban Forestry Degree & 1 & 2 & 3 & 4 & 5 \\
\hline Ecological Society of America Certified Ecologist & 1 & 2 & 3 & 4 & 5 \\
\hline $\begin{array}{l}\text { American Society of Landscape Architects Accredited } \\
\text { Degree }\end{array}$ & 1 & 2 & 3 & 4 & 5 \\
\hline Public Administration Certification & 1 & 2 & 3 & 4 & 5 \\
\hline SAF Certified Forester & 1 & 2 & 3 & 4 & 5 \\
\hline Professional Engineer Certification & 1 & 2 & 3 & 4 & 5 \\
\hline American Institute of Certified Planners Certification & 1 & 2 & 3 & 4 & 5 \\
\hline
\end{tabular}

16. Please rate the importance of an entry-level urban forester to possess a certificate issued by a university in urban forestry. This certificate would be awarded after the completion of a series of undergraduate level classes, but less than what is required for a bachelor's degree. (On a scale from 1 to 5 with 1 being not important and 5 being very important)

\begin{tabular}{|c|c|c|c|c|c|}
\hline & 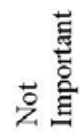 & & 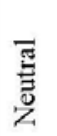 & & 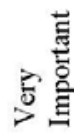 \\
\hline University Certificate & 1 & 2 & 3 & 4 & 5 \\
\hline
\end{tabular}


Demographics

17. What is your gender?

Male

Female

18. What is your age?

19. What is the highest level of education you have completed? (Please check one only) High school diploma

2 year technical or associates degree

4 year college degree

Graduate degree

Doctorate degree

20. Which area of study would best describe your educational background? (Please check one only) Horticulture

Forestry

Urban Forestry

Arboriculture

Urban Planning

Landscape Architecture

Public Administration

Environmental Science

Recreation Management

Civil Engineering

Natural Resource Management

Geography

Sustainability Studies

Other degree or program

21. How many people do you manage currently?

22. How many years have you been working in the field of urban forestry?

23. How many years have you been working in the field of urban forestry in a management position?

Thank you for completing this survey, your input is important.

Please return the completed survey in the postage paid envelope provided. 


\title{
Appendix XV: Introductory emails and both questionnaires
}

\author{
Figure 1: Email introductions for online questionnaire
}

Dear Steering Committee Member,

This email is to inform you of a new online survey we have developed at West Virginia University as part of the Urban Forestry 2020 research project. This research is funded in part by the National Urban and Community Forestry Advisory Council (NUCFAC). It is our hope that you will help by participating in and distributing it.

This survey explores the perceptions of employers in urban forestry regarding entry-level urban foresters. The survey asks what skills and knowledge are most important to employers. This will play an important role in achieving the goal of the UF 2020 group of evaluating the status of the profession of urban forestry. This survey complements a paper based survey being sent out to the top 200 most populous cities in the United States, which asks their urban forestry departments these same questions. The hope for this online survey is that the urban foresters in the other areas of the profession will also be represented in this study.

Please take this survey if you are an employer in urban forestry in any aspect of the profession (municipal, county, state, private sector or non-profit organization).

The success of this online survey depends on a wide distribution of this announcement. We ask that you send the link for the survey to any urban forestry professionals in the United States that have the responsibility of managing and hiring entry-level urban foresters. We appreciate all the help.

Thank you very much for your contributions to date and your ongoing assistance in our research.

Dear Urban Forestry Professional,

This email is to inform you of an online survey and ask your help with participating and distributing it. This survey was developed by researchers at West Virginia University as part of the Urban Forestry 2020 group commissioned by the National Urban and Community Forestry Advisory Council (NUCFAC). We are evaluating the status of the profession of urban forestry and in order to help guide its direction going into the future.

This online survey is part of this effort and explores the perceptions of employers in urban forestry regarding entry-level urban foresters. The survey asks these employers what skills and knowledge they find the most valuable and which skills and knowledge are most needed in these entry-level employees. This online survey is a supplement to a physical mail survey of the largest 200 cities throughout the United States. The hope is this online survey will capture the input of urban forestry employers in the other areas of the profession besides large municipalities that was explored in the mail survey.

Please take this survey if you are an employer in urban forestry in any aspect of the profession (municipal, county, state, private sector or non-profit organization).

The success of this online survey depends on a wide distribution of this announcement. We ask that you forward this link to any urban forestry professionals that have the responsibility of managing and hiring entry-level urban foresters. 


\title{
Appendix XVI
}

\author{
Figure 1: Online Questionnaire
}

\begin{abstract}
About This Survey
The purpose of this research is to explore employer perceptions of the individuals applying for entry-level positions in the field of urban forestry. Your insights will provide helpful information to guide the profession of urban forestry as it progresses into the future. The urban forestry profession is undergoing a self-evaluation process. This survey is part of Urban Forestry 2020, a 3-year program helping to shape this evaluation and will be used to make strategic decisions concerning education, recruitment, and professional development opportunities in urban forestry.

Definitions: For the purpose of this research we will use the following terms as defined below.

Arboriculture is the inspection, maintenance, and protection of landscape trees to ensure their health and safety in the human environment.

Urban Forestry is the planning and management of tree resources in and around urban areas the benefit of people and the environment.

Urban Forester is an individual that may still perform arboricultural tasks but works primarily towards planning and managing urban trees at a community scale rather than a site scale

Entry-level Position would be a role within your municipality that could be filled by someone who may or may not have job specific education/training and minimal experience performing the type of work required.
\end{abstract}

Your participation is voluntary and you have the right to refrain from answering any questions. If you choose to participate, your answers will be kept confidential.

Thank you for your assistance with this important research!

1. Where do you perform the majority of your work? (Please provide the city name)

2. Of the following choices, which would be the most appropriate to describe the area of urban forestry in which you work? (Please check only one)

Non-profit organization

Environmental consulting firm

Urban forestry consulting firm

Tree care companies

Other for-profit business

Federal government

State government

Local government, small (population of 59,999 or less)

Local government, small (population of 60,000 to 129,999 )

Local government, medium (population of 130,000 to 249,999 )

Local government, medium (population of 250,000 to 499,999 )

Local government, large (population of 500,000 to 999,999 )

Local government, large (population of $1,000,000$ or more)

Utility management

Property managers \& homeowner associations 
3. How many urban foresters are employed by your establishment? (Please provide a number)

4. How many entry-level urban foresters are employed by your establishment? (Please provide a number)

5. How many entry-level urban foresters do you predict will be hired by your establishment in the next year? (Please provide a number)

6. Of those hired how many will be new positions (i.e. not filling vacancies)? (Please provide a number)

7. How many entry-level urban foresters do you anticipate will be hired by your establishment in the next five years? (Please provide a number)

8. Of those hired how many will be new positions (i.e. not filling vacancies)? (Please provide a number)

9. What is your estimate for the starting salary of an entry-level urban forester at your establishment?

$\$ 24,999$ or less

$\$ 25,000$ to 29,999

$\$ 30,000$ to 34,999

$\$ 35,000$ to 39,999

$\$ 40,000$ to 44,999

$\$ 45,000$ to 49,999

$\$ 50,000$ to 54,999

$\$ 55,000$ to 59,999

$\$ 60,000$ to 64,999

$\$ 65,000$ to 69,999

$\$ 70,000$ or more

I don't know

10. Please rate the importance for an entry-level urban forester to possess each of the following skills. (On a scale from 1 to 5 with 1 being not important and 5 being very important)

\begin{tabular}{|c|c|c|c|c|c|}
\hline Technical Urban Forestry & 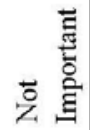 & & 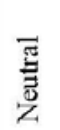 & & 焉 \\
\hline Tree inventory techniques & 1 & 2 & 3 & 4 & 5 \\
\hline Urban wildlife management & 1 & 2 & 3 & 4 & 5 \\
\hline
\end{tabular}




\begin{tabular}{|l|c|c|c|c|c|}
\hline GIS and geospatial technologies & 1 & 2 & 3 & 4 & 5 \\
\hline Urban forest management principles & 1 & 2 & 3 & 4 & 5 \\
\hline Municipal urban forest resource policy & 1 & 2 & 3 & 4 & 5 \\
\hline Federal urban forest resource policy & 1 & 2 & 3 & 4 & 5 \\
\hline Site plan review & 1 & 2 & 3 & 4 & 5 \\
\hline Water regulations & 1 & 2 & 3 & 4 & 5 \\
\hline Green infrastructure planning & 1 & 2 & 3 & 4 & 5 \\
\hline Resiliency planning/disaster recovery & 1 & 2 & 3 & 4 & 5 \\
\hline
\end{tabular}

\begin{tabular}{|c|c|c|c|c|c|}
\hline Technical Forestry & 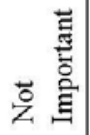 & & $\begin{array}{l}\overline{\text { चु }} \\
\text { 言 } \\
\text { Z }\end{array}$ & & 家害 \\
\hline Soil Science & 1 & 2 & 3 & 4 & 5 \\
\hline Plant physiology & 1 & 2 & 3 & 4 & 5 \\
\hline Ecology & 1 & 2 & 3 & 4 & 5 \\
\hline Park administration/management & 1 & 2 & 3 & 4 & 5 \\
\hline Hydrology/Watershed management & 1 & 2 & 3 & 4 & 5 \\
\hline Climate science & 1 & 2 & 3 & 4 & 5 \\
\hline Weed and vegetation control & 1 & 2 & 3 & 4 & 5 \\
\hline
\end{tabular}

\begin{tabular}{|c|c|c|c|c|c|}
\hline Technical Arboricultural & 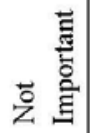 & & 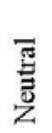 & & 总莺 \\
\hline Insect and disease control & 1 & 2 & 3 & 4 & 5 \\
\hline Shade and street tree species selection & 1 & 2 & 3 & 4 & 5 \\
\hline Tree planting techniques & 1 & 2 & 3 & 4 & 5 \\
\hline Tree nutrition and fertilization & 1 & 2 & 3 & 4 & 5 \\
\hline
\end{tabular}

Page | 3 


\begin{tabular}{|c|c|c|c|c|c|}
\hline Tree pruning and removal techniques & 1 & 2 & 3 & 4 & 5 \\
\hline Root management and root pruning & 1 & 2 & 3 & 4 & 5 \\
\hline Water management and irrigation & 1 & 2 & 3 & 4 & 5 \\
\hline Landscape construction & 1 & 2 & 3 & 4 & 5 \\
\hline Landscape management & 1 & 2 & 3 & 4 & 5 \\
\hline Tree identification & 1 & 2 & 3 & 4 & 5 \\
\hline Tree support and lightning protection & 1 & 2 & 3 & 4 & 5 \\
\hline Tree disorder diagnostics & 1 & 2 & 3 & 4 & 5 \\
\hline Plant materials/nursery stock quality & 1 & 2 & 3 & 4 & 5 \\
\hline Tree appraisal & 1 & 2 & 3 & 4 & 5 \\
\hline Principles of utility management & 1 & 2 & 3 & 4 & 5 \\
\hline Tree preservation & 1 & 2 & 3 & 4 & 5 \\
\hline Tree assessment and risk management & 1 & 2 & 3 & 4 & 5 \\
\hline Worker safety & 1 & 2 & 3 & 4 & 5 \\
\hline Heavy equipment operation & 1 & 2 & 3 & 4 & 5 \\
\hline Tree climbing & 1 & 2 & 3 & 4 & 5 \\
\hline Managerial & 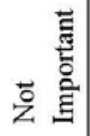 & & $\begin{array}{l}\text { च } \\
\text { 吾 } \\
\text { 乙 }\end{array}$ & & 家䓂 \\
\hline Budgeting & 1 & 2 & 3 & 4 & 5 \\
\hline Business management & 1 & 2 & 3 & 4 & 5 \\
\hline Employee supervision & 1 & 2 & 3 & 4 & 5 \\
\hline Training/teaching & 1 & 2 & 3 & 4 & 5 \\
\hline Project management & 1 & 2 & 3 & 4 & 5 \\
\hline Contract administration & 1 & 2 & 3 & 4 & 5 \\
\hline
\end{tabular}

Page | 4 


\begin{tabular}{|c|c|c|c|c|c|}
\hline Computer skills/database management & 1 & 2 & 3 & 4 & 5 \\
\hline Communication & 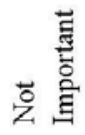 & & $\begin{array}{l}\bar{\pi} \\
\bar{z} \\
\bar{z}\end{array}$ & & 总莺 \\
\hline Written communication & 1 & 2 & 3 & 4 & 5 \\
\hline Public relations/customer service & 1 & 2 & 3 & 4 & 5 \\
\hline Oral communication & 1 & 2 & 3 & 4 & 5 \\
\hline Conflict resolution & 1 & 2 & 3 & 4 & 5 \\
\hline Media relations & 1 & 2 & 3 & 4 & 5 \\
\hline Social media/internet based media & 1 & 2 & 3 & 4 & 5 \\
\hline
\end{tabular}

\begin{tabular}{|c|c|c|c|c|c|}
\hline Public Administration & 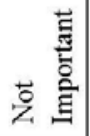 & & $\begin{array}{l}\overline{\mathrm{E}} \\
\bar{z}\end{array}$ & & 完言 \\
\hline Political science & 1 & 2 & 3 & 4 & 5 \\
\hline Land use planning & 1 & 2 & 3 & 4 & 5 \\
\hline Community outreach/public engagement & 1 & 2 & 3 & 4 & 5 \\
\hline Public administration & 1 & 2 & 3 & 4 & 5 \\
\hline Volunteer organization & 1 & 2 & 3 & 4 & 5 \\
\hline Multicultural competency & 1 & 2 & 3 & 4 & 5 \\
\hline Ordinance enforcement & 1 & 2 & 3 & 4 & 5 \\
\hline Grant writing & 1 & 2 & 3 & 4 & 5 \\
\hline Professional ethics & 1 & 2 & 3 & 4 & 5 \\
\hline Permitting and compliance & 1 & 2 & 3 & 4 & 5 \\
\hline
\end{tabular}

11. Please rate the prevalence for an entry-level urban forester to possess each of the following skills. (On a scale from 1 to 5 with 1 often lacking and 5 being often present)

Page | 5 


\begin{tabular}{|c|c|c|c|c|c|}
\hline Technical Urban Forestry & 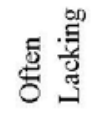 & & 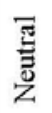 & & 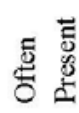 \\
\hline Tree inventory techniques & 1 & 2 & 3 & 4 & 5 \\
\hline Urban wildlife management & 1 & 2 & 3 & $\overline{4}$ & 5 \\
\hline GIS and geospatial technologies & 1 & 2 & 3 & 4 & 5 \\
\hline Urban forest management principles & 1 & 2 & 3 & 4 & 5 \\
\hline Municipal urban forest resource policy & 1 & 2 & 3 & 4 & 5 \\
\hline Federal urban forest resource policy & 1 & 2 & 3 & 4 & 5 \\
\hline Site plan review & 1 & 2 & 3 & 4 & 5 \\
\hline Water regulations & 1 & 2 & 3 & 4 & 5 \\
\hline Green infrastructure planning & 1 & 2 & 3 & 4 & 5 \\
\hline Resiliency planning/disaster recovery & 1 & 2 & 3 & 4 & 5 \\
\hline
\end{tabular}

\begin{tabular}{|c|c|c|c|c|c|}
\hline Technical Forestry & 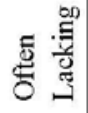 & & 焉 & & 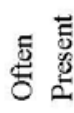 \\
\hline Soil Science & 1 & 2 & 3 & 4 & 5 \\
\hline Plant physiology & 1 & 2 & 3 & 4 & 5 \\
\hline Ecology & 1 & 2 & 3 & 4 & 5 \\
\hline Park administration/management & 1 & 2 & 3 & 4 & 5 \\
\hline Hydrology/Watershed management & 1 & 2 & 3 & 4 & 5 \\
\hline Climate science & 1 & 2 & 3 & 4 & 5 \\
\hline Weed and vegetation control & 1 & 2 & 3 & 4 & 5 \\
\hline
\end{tabular}

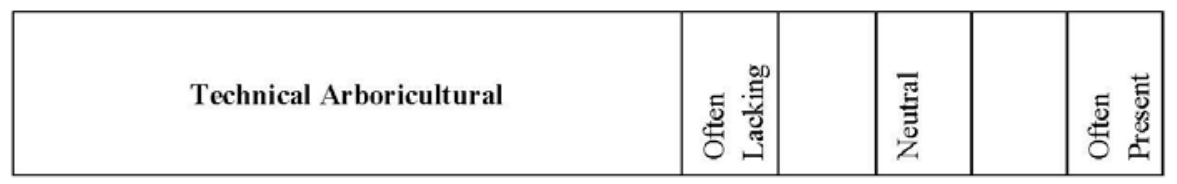

Page | 6 


\begin{tabular}{|c|c|c|c|c|c|}
\hline Insect and disease control & 1 & 2 & 3 & 4 & 5 \\
\hline Shade and street tree species selection & 1 & 2 & 3 & 4 & 5 \\
\hline Tree planting techniques & 1 & 2 & 3 & 4 & 5 \\
\hline Tree nutrition and fertilization & 1 & 2 & 3 & 4 & 5 \\
\hline Tree pruning and removal techniques & 1 & 2 & 3 & 4 & 5 \\
\hline Root management and root pruning & 1 & 2 & 3 & 4 & 5 \\
\hline Water management and irrigation & 1 & 2 & 3 & 4 & 5 \\
\hline Landscape construction & 1 & 2 & 3 & 4 & 5 \\
\hline Landscape management & 1 & 2 & 3 & 4 & 5 \\
\hline Tree identification & 1 & 2 & 3 & 4 & 5 \\
\hline Tree support and lightning protection & 1 & 2 & 3 & 4 & 5 \\
\hline Tree disorder diagnostics & 1 & 2 & 3 & 4 & 5 \\
\hline Plant materials/nursery stock quality & 1 & 2 & 3 & 4 & 5 \\
\hline Tree appraisal & 1 & 2 & 3 & 4 & 5 \\
\hline Principles of utility management & 1 & 2 & 3 & 4 & 5 \\
\hline Tree preservation & 1 & 2 & 3 & 4 & 5 \\
\hline Tree assessment and risk management & 1 & 2 & 3 & 4 & 5 \\
\hline Worker safety & 1 & 2 & 3 & 4 & 5 \\
\hline Heavy equipment operation & 1 & 2 & 3 & 4 & 5 \\
\hline Tree climbing & 1 & 2 & 3 & 4 & 5 \\
\hline Managerial & 音 & & 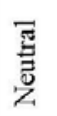 & & 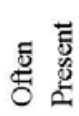 \\
\hline Budgeting & 1 & 2 & 3 & 4 & 5 \\
\hline Business management & 1 & 2 & 3 & 4 & 5 \\
\hline
\end{tabular}

Page | 7 


\begin{tabular}{|l|c|c|c|c|c|}
\hline Employee supervision & 1 & 2 & 3 & 4 & 5 \\
\hline Training/teaching & 1 & 2 & 3 & 4 & 5 \\
\hline Project management & 1 & 2 & 3 & 4 & 5 \\
\hline Contract administration & 1 & 2 & 3 & 4 & 5 \\
\hline Computer skills/database management & 1 & 2 & 3 & 4 & 5 \\
\hline
\end{tabular}

\begin{tabular}{|c|c|c|c|c|c|}
\hline Communication & 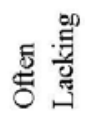 & & 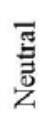 & & 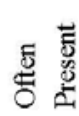 \\
\hline Written communication & 1 & 2 & 3 & 4 & 5 \\
\hline Public relations/customer service & 1 & 2 & 3 & 4 & 5 \\
\hline Oral communication & 1 & 2 & 3 & 4 & 5 \\
\hline Conflict resolution & 1 & 2 & 3 & 4 & 5 \\
\hline Media relations & 1 & 2 & 3 & 4 & 5 \\
\hline Social media/internet based media & 1 & 2 & 3 & 4 & 5 \\
\hline
\end{tabular}

\begin{tabular}{|c|c|c|c|c|c|}
\hline Public Administration & 竘离 & & 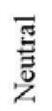 & & 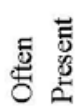 \\
\hline Political science & 1 & 2 & 3 & 4 & 5 \\
\hline Land use planning & 1 & 2 & 3 & 4 & 5 \\
\hline Community outreach/public engagement & 1 & 2 & 3 & 4 & 5 \\
\hline Public administration & 1 & 2 & 3 & 4 & 5 \\
\hline Volunteer organization & 1 & 2 & 3 & 4 & 5 \\
\hline Multicultural competency & 1 & 2 & 3 & 4 & 5 \\
\hline Ordinance enforcement & 1 & 2 & 3 & 4 & 5 \\
\hline Grant writing & 1 & 2 & 3 & 4 & 5 \\
\hline
\end{tabular}

Page | 8 


\begin{tabular}{|l|c|c|c|c|c|}
\hline Professional ethics & 1 & 2 & 3 & 4 & 5 \\
\hline Permitting and compliance & 1 & 2 & 3 & 4 & 5 \\
\hline
\end{tabular}

12. Please rate the importance for an entry-level urban forester to have the following education. (On a scale from 1 to 5 with 1 being not important and 5 being very important)

\begin{tabular}{|c|c|c|c|c|c|}
\hline Education Level & 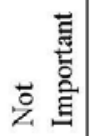 & & 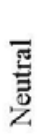 & & 家突 \\
\hline High school diploma & 1 & 2 & 3 & 4 & 5 \\
\hline 2 year technical or associates degree & 1 & 2 & 3 & 4 & 5 \\
\hline 4 year college degree & 1 & 2 & 3 & 4 & 5 \\
\hline Graduate degree & 1 & 2 & 3 & 4 & 5 \\
\hline Doctorate degree & 1 & 2 & 3 & 4 & 5 \\
\hline
\end{tabular}

13. Please rate the prevalence for an entry level urban forestry to have completed the following education. (On a scale from 1 to 5 with 1 being not important and 5 being very important)

\begin{tabular}{|c|c|c|c|c|c|}
\hline Education Level & 总兽兽 & & 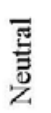 & & 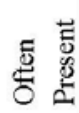 \\
\hline High school diploma & 1 & 2 & 3 & 4 & 5 \\
\hline 2 year technical or associates degree & 1 & 2 & 3 & 4 & 5 \\
\hline 4 year college degree & 1 & 2 & 3 & 4 & 5 \\
\hline Graduate degree & 1 & 2 & 3 & 4 & 5 \\
\hline Doctorate degree & 1 & 2 & 3 & 4 & 5 \\
\hline
\end{tabular}

14. Please rate the importance for an entry-level urban forester to possess a degree in the following areas of study. (On a scale from 1 to 5 with 1 being not important and 5 being very important)

\begin{tabular}{|c|c|c|c|}
\hline Area of Study & 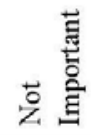 & 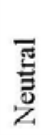 & 灾芯 \\
\hline
\end{tabular}




\begin{tabular}{|l|c|c|c|c|c|}
\hline Horticulture & 1 & 2 & 3 & 4 & 5 \\
\hline Forestry & 1 & 2 & 3 & 4 & 5 \\
\hline Urban Forestry & 1 & 2 & 3 & 4 & 5 \\
\hline Arboriculture & 1 & 2 & 3 & 4 & 5 \\
\hline Urban Planning & 1 & 2 & 3 & 4 & 5 \\
\hline Landscape Architecture & 1 & 2 & 3 & 4 & 5 \\
\hline Public Administration & 1 & 2 & 3 & 4 & 5 \\
\hline Environmental Science & 1 & 2 & 3 & 4 & 5 \\
\hline Recreation Management & 1 & 2 & 3 & 4 & 5 \\
\hline Civil Engineering & 1 & 2 & 3 & 4 & 5 \\
\hline Natural Resource Management & 1 & 2 & 3 & 4 & 5 \\
\hline Other degree & 1 & 2 & 3 & 4 & 5 \\
\hline
\end{tabular}

15. Please rate the importance for an entry-level urban forester to possess the following practical knowledge and credentials. (On a scale from 1 to 5 with 1 being not important and 5 being very important)

\begin{tabular}{|l|c|c|c|c|c|}
\hline \multicolumn{1}{|c|}{ Practical Experience and Credentials } & r & & & 焉 \\
\hline $\begin{array}{l}3 \text { months or less of practical experience or internship } \\
\text { experience }\end{array}$ & 1 & 2 & 3 & 4 & 5 \\
\hline $\begin{array}{l}\text { 6 months or less of practical experience or internship } \\
\text { experience }\end{array}$ & 1 & 2 & 3 & 4 & 5 \\
\hline $\begin{array}{l}\text { 9 months or less of practical experience or internship } \\
\text { experience }\end{array}$ & 1 & 2 & 3 & 4 & 5 \\
\hline $\begin{array}{l}\text { More than 9 months of practical experience or } \\
\text { internship experience }\end{array}$ & 1 & 2 & 3 & 4 & 5 \\
\hline
\end{tabular}




\begin{tabular}{|c|c|c|c|c|c|}
\hline Credentials & 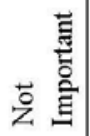 & & 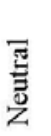 & & 总言 \\
\hline $\begin{array}{l}\text { International Society of Arboriculture (ISA) Certified } \\
\text { Arborist }\end{array}$ & 1 & 2 & 3 & 4 & 5 \\
\hline ISA Certified Arborist Municipal Specialist & 1 & 2 & 3 & 4 & 5 \\
\hline Commercial pesticide applicator license & 1 & 2 & 3 & 4 & 5 \\
\hline Commercial driver's license & 1 & 2 & 3 & 4 & 5 \\
\hline $\begin{array}{l}\text { Society of American Foresters (SAF) Accredited } \\
\text { Forestry Degree }\end{array}$ & 1 & 2 & 3 & 4 & 5 \\
\hline SAF Accredited Urban Forestry Degree & 1 & 2 & 3 & 4 & 5 \\
\hline Ecological Society of America Certified Ecologist & 1 & 2 & 3 & 4 & 5 \\
\hline $\begin{array}{l}\text { American Society of Landscape Architects Accredited } \\
\text { Degree }\end{array}$ & 1 & 2 & 3 & 4 & 5 \\
\hline Public Administration Certification & 1 & 2 & 3 & 4 & 5 \\
\hline SAF Certified Forester & 1 & 2 & 3 & 4 & 5 \\
\hline Professional Engineer Certification & 1 & 2 & 3 & 4 & 5 \\
\hline American Institute of Certified Planners Certification & 1 & 2 & 3 & 4 & 5 \\
\hline
\end{tabular}

16. Please rate the importance of an entry-level urban forester to possess a certificate issued by a university in urban forestry. This certificate would be awarded after the completion of a series of undergraduate level classes, but less than what is required for a bachelor's degree. (On a scale from 1 to 5 with 1 being not important and 5 being very important)

\begin{tabular}{|c|c|c|c|c|c|c|}
\hline & & 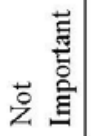 & & 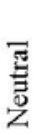 & & 莺总 \\
\hline University Certificate & & 1 & 2 & 3 & 4 & 5 \\
\hline \multicolumn{7}{|l|}{ Demographics } \\
\hline $\begin{array}{l}\text { 17. What is your gender? } \\
18 . \text { What is your age? }\end{array}$ & Male & \multicolumn{3}{|c|}{ Female } & & \\
\hline
\end{tabular}

Page | 11 
2 year technical or associates degree

4 year college degree

Graduate degree

Doctorate degree

20. Which area of study would best describe your educational background? (Please check one only) Horticulture

Forestry

Urban Forestry

Arboriculture

Urban Planning

Landscape Architecture

Public Administration

Environmental Science

Recreation Management

Civil Engineering

Natural Resource Management

Geography

Sustainability Studies

Other degree or program

21 . How many people do you manage currently?

22. How many years have you been working in the field of urban forestry?

23. How many years have you been working in the field of urban forestry in a management position?

Thank you for completing this survey, your input is important.

Please return the completed survey in the postage paid envelope provided. 


\section{Appendix XVII}

Figure 1: Hiring by State Mail Questionnaire Results

\begin{tabular}{|c|c|c|c|c|}
\hline State & $\begin{array}{l}\text { No. of Entry Hires } \\
\text { in Next Year }\end{array}$ & $\begin{array}{l}\text { No. of Entry Hires in Next } \\
\text { Year to New Positions }\end{array}$ & $\begin{array}{l}\text { No. of Entry Hires } \\
\text { in Next Five Years }\end{array}$ & $\begin{array}{l}\text { No. of Entry Hires in Next } \\
\text { Five Years to New Positions }\end{array}$ \\
\hline Alabama & 0 & 0 & 0 & 0 \\
\hline Alaska & 0 & 0 & 0 & 0 \\
\hline Arizona & 0 & 0 & 3 & 1 \\
\hline California & 0 & 0 & 5 & 3 \\
\hline Colorado & 2 & 0 & 3 & 1 \\
\hline Connecticut & 1 & 0 & 3 & 0 \\
\hline Florida & 2 & 2 & 4 & 3 \\
\hline Georgia & 1 & 1 & 1 & 1 \\
\hline Illinois & 0 & 0 & 0 & 0 \\
\hline Indiana & 1 & 0 & 4 & 1 \\
\hline lowa & 0 & 0 & 2 & 2 \\
\hline Kansas & 4 & 2 & 9 & 2 \\
\hline Kentucky & 1 & 1 & 5 & 5 \\
\hline Louisiana & 0 & 0 & 3 & 2 \\
\hline Maryland & 1 & 1 & 1 & 1 \\
\hline Massachusetts & 0 & 0 & 1 & 0 \\
\hline Michigan & 0 & 0 & 2 & 2 \\
\hline Minnesota & 0 & 0 & 1 & 0 \\
\hline Missouri & 4 & 0 & 6 & 1 \\
\hline Nebraska & 3 & 0 & 6 & 3 \\
\hline Nevada & 0 & 0 & 0 & 0 \\
\hline New Jersey & 0 & 0 & 0 & 0 \\
\hline New York & 10 & 0 & 51 & 1 \\
\hline North Carolina & 0 & 0 & 2 & 0 \\
\hline Ohio & 1 & 0 & 5 & 1 \\
\hline Oklahoma & 0 & 0 & 1 & 1 \\
\hline Oregon & 0 & 0 & 1 & 1 \\
\hline Pennsylvania & 2 & 0 & 5 & 3 \\
\hline South Carolina & 0 & 0 & 0 & 0 \\
\hline South Dakota & 0 & 0 & 0 & 0 \\
\hline Tennessee & 1 & 1 & 3 & 1 \\
\hline Texas & 3 & 1 & 11 & 10 \\
\hline Utah & 0 & 0 & 1 & 1 \\
\hline Virginia & 0 & 0 & 2 & 2 \\
\hline Washington & 1 & 0 & 1 & 1 \\
\hline Wisconsin & 1 & 0 & 2 & 0 \\
\hline
\end{tabular}


Figure 2: Hiring by State Online Questionnaire Results

\begin{tabular}{|c|c|c|c|c|}
\hline State & $\begin{array}{l}\text { No. of Entry Hires } \\
\text { in Next Year }\end{array}$ & $\begin{array}{l}\text { No. of Entry Hires in Next } \\
\text { Year to New Positions }\end{array}$ & $\begin{array}{l}\text { No. of Entry Hires } \\
\text { in Next Five Years }\end{array}$ & $\begin{array}{l}\text { No. of Entry Hires in Next } \\
\text { Five Years to New Positions }\end{array}$ \\
\hline Arizona & 2 & 2 & 2 & 2 \\
\hline California & 3 & 1 & 13 & 8 \\
\hline Colorado & 3 & 0 & 5 & 3 \\
\hline Connecticut & 1 & 1 & 2 & 2 \\
\hline Florida & 0 & 0 & 0 & 0 \\
\hline Georgia & 0 & 0 & 0 & 0 \\
\hline Idaho & 1 & 0 & 2 & 2 \\
\hline Illinois & 4 & 6 & 16 & 8 \\
\hline Indiana & 2 & 1 & 6 & 5 \\
\hline lowa & 1 & 0 & 7 & 5 \\
\hline Maryland & 3 & 1 & 1 & 0 \\
\hline Massachusetts & 0 & 0 & 0 & 0 \\
\hline Michigan & 13 & 7 & 32 & 12 \\
\hline Minnesota & 0 & 0 & 2 & 2 \\
\hline Missouri & 5 & 3 & 30 & 10 \\
\hline Montana & 1 & 0 & 10 & 4 \\
\hline Nebraska & 0 & 0 & 1 & 1 \\
\hline New Jersey & 0 & 0 & 1 & 1 \\
\hline New York & 88 & 11 & 265 & 34 \\
\hline Ohio & 10 & 4 & 35 & 28 \\
\hline Oregon & 0 & 0 & 1 & 0 \\
\hline Pennsylvania & 2 & 2 & 12 & 9 \\
\hline Rhode Island & 0 & 0 & 0 & 0 \\
\hline South Carolina & 0 & 0 & 0 & 0 \\
\hline Tennessee & 4 & 4 & 0 & 0 \\
\hline Texas & 2 & 0 & 5 & 1 \\
\hline Virginia & 55 & 36 & 221 & 129 \\
\hline Washington & 1 & 1 & 8 & 8 \\
\hline West Virginia & 3 & 0 & 7 & 2 \\
\hline Wisconsin & 2 & 0 & 4 & 1 \\
\hline Wyoming & 1 & 1 & 5 & 3 \\
\hline $\begin{array}{l}\text { Washington, } \\
\text { D.C. }\end{array}$ & 7 & 4 & 14 & 8 \\
\hline
\end{tabular}

